\title{
Logística em Serviços de Saúde
}

\section{Quésia Postigo Kamimura}

Tese a apresentada ao Programa de PósGraduação da Faculdade de Saúde Pública da Universidade de São Paulo para obtenção do título de Doutor em Saúde Pública.

Área de Concentração: Serviços de Saúde Pública.

Orientadora: Profa. Dra. Vitória Kedy Cornetta.

São Paulo

2009

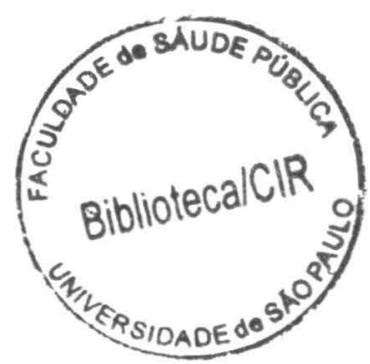


É expressamente proibida a comercialização deste documento tanto na sua forma impressa como eletrônica. Sua reprodução total ou parcial é permitida exclusivamente para fins acadêmicos e científicos, desde que na reprodução figure a identificação do autor, título, instituição e ano da tese.

$$
50720 / 2009 \text { doc }
$$




\section{AGRADECIMENTOS}

À Profa. Dra. Vitória Kedy Cornetta, agradecimento especial, pelo acolhimento, apoio, amizade e energia nos momentos mais dificeis, ofereceu todo suporte para a conclusão deste trabalho.

Ao Prof. Dr. Olímpio José Nogueira Viana Bittar pela orientação na primeira fase e compreensão nos momentos em que a vida, ou melhor, a efemeridade da vida gritou mais alto do que as atividades acadêmicas.

Aos membros da banca examinadora, pelas orientações e sugestões que muito enriqueceram e contribuíram para o aprimoramento do estudo.

Ao Prof. Dr. Gilson de Cássia Carvalho, que há muito, quando ainda era aluna da especialização, tem aguçado meus questionamentos e vontade de estudar e sempre aponta para novas reflexões.

À amiga e Profa. Dra. Vera Lúcia Ignácio Molina pela generosidade em acolher no emocional e em compartilhar seus conhecimentos nas discussões que muito contribuíram para esta tese.

Ao Prof. Dr. Marcos Kisil e Dr. Álvaro Escrivão Junior, cujos comentários e questionamentos no Exame de Qualificação foram valiosos.

Às lideranças das instituições pesquisadas e aos profissionais entrevistados pela colaboração em tornar a pesquisa viável.

A todos amigos e professores que, direta ou indiretamente, participaram e contribuíram para a conclusão deste trabalho o meu MUITO OBRIGADO!

À Renilda, Cidinha e Vânia por toda atenção, amizade e profissionalismo, muito obrigada.

À irmã espiritual Miroslava Hamzagic que compartilhamos juntas a empreitada do doutorado. 
À amiga Maria Lúcia Fadel Condino pela companhia na época das disciplinas e depois pelo ombro amigo em tempos de dor.

Aos meus familiares, minha mãe, meu pai, meu irmão, minhas cunhadas, meus cunhados e meus queridos sobrinhos, que muito me apoiaram durante o periodo de realização desta tese.

E sobretudo à DEUS. 


\section{RESUMO}

KAMIMURA, Q.P. Logística em Serviços de Saúde. 2009. 139 p. Tese (Doutorado em Saúde Pública) - Faculdade de Saúde Pública, Universidade de São Paulo, São Paulo,

Introdução: a logística sempre existiu, cresceu na arte da guerra e tornou-se conhecida como uma estratégia de grande oportunidade no mundo atual das organizações. Objetivo: analisar o sistema logístico de serviços de saúde com relação a hospitais, públicos e privados, no município de São Paulo. Procedimentos Metodológicos: numa abordagem qualitativa, utilizou-se da estratégia de estudos de caso e das técnicas de entrevista semi-estruturada, pesquisa documental e observação direta, para conhecer a gestão dos serviços de saúde, públicos e privados, diante do novo paradigma da logística. Resultados: as organizações hospitalares vêm recentemente incorporando em suas gestões os conceitos atuais de logística e criando seus próprios modelos; o sistema logístico de cada um dos estabelecimentos estudados reserva diferentes características e está em diferentes estágios; os fluxos de materiais, financeiro e de informação não estão plenamente integrados, apresentam iniciativas de canais e fluxos reversos; o just-in-time nas circunstâncias atuais, segundo os executivos entrevistados, não é aplicável ao ambiente hospitalar; as organizações estão investindo na inovação tecnológica de gestão logística e os indicadores logísticos, quando há monitoramento, estão em fase de construção. Conclusão: a plena integração do sistema logístico é um desafio a ser alcançado no processo evolutivo do novo paradigma da logística, e outro desafio é o equilíbrio entre eficiência e responsividade da cadeia de suprimentos da saúde. Os gestores devem estar alinhados à gestão de saúde, e no árduo trabalho diário em que enfrentam a correnteza de tantos interesses desafiam o não esmorecer em arquear diretamente o alvo - tratamento e atenção à pessoa humana.

Descritores: Hospitais; Logística; cadeia de suprimento; Serviços de Saúde. 


\section{SUMMARY}

KAMIMURA, Q.P. Logistics in Healthcare Services. 2009. 139 p. Thesis (Doutorado em Saúde Pública) - Faculdade de Saúde Pública, Universidade de São Paulo, São Paulo.

Introduction: the logistics always existed, grew up in the art of war and became known as a strategy of great opportunity in today's world of organizations. Objective: to examine the logistics system of health services in relation to hospitals, public and private, in São Paulo. Methodological procedures: a qualitative approach was used the strategy of case studies and the techniques of semi-structured interviews, desk research and direct observation, to learn the management of health services, public and private, before the new paradigm of logistics. Results: the hospital organizations have recently incorporated into their current management concepts and logistics of creating their own models, the logistic system of each of the establishments studied reserve and is different in different stages, the flow of material, financial and information not are fully integrated, present initiatives of channels and reverse flows, the just-in-time in the current circumstances, according to executives interviewed, it is not applicable to hospitals, organizations are investing in technology logistics management and logistics indicators, when there is monitoring, are under construction. Conclusion: the full integration of the logistics system is a challenge to be achieved in the evolutionary process of the new paradigm of logistics, and another challenge is the balance between efficiency and responsiveness of the supply chain of health. Managers should be aligned to the management of health, and the daily hard work in facing the current challenge the interests of many non-fading hook directly into the target - the treatment and attention to the human person.

Keywords: Hospitals; Logistics, supply chain, Health Services. 


\section{ÍNDICE}

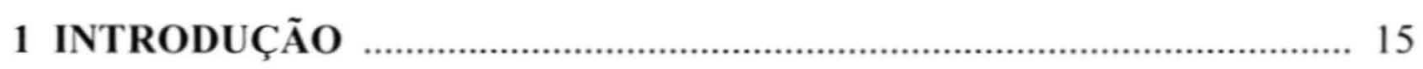

1.1 SERVIÇOS DE SAÚDE E ASSISTÊNCIA HOSPITALAR .................... 21

1.1.1 Caracterização dos Hospitais ....................................................... 29

1.1.2 Hospitais: Públicos e Privados...................................................... 32

1.1.3 O mix público-privado ................................................................. 35

1.2 EVOLUÇÃO E CONCEITO DE LOGÍSTICA E SUPPLY CHAIN.......... 38

1.3 LOGÍSTICA E SERVIÇOS DE SAÚDE …………………………….... 48

1.4 MENTALIDADE ENXUTA E O COMPONENTE LOGÍSTICA …......... 54

1.5 DESEMPENHO LOGÍSTICO ............................................................. 56

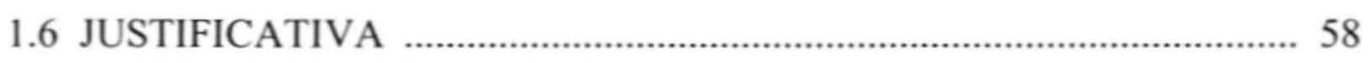

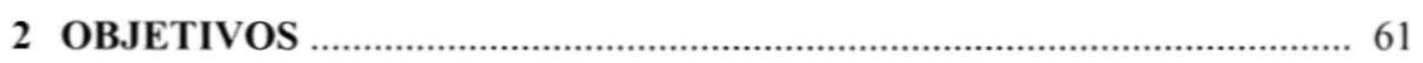

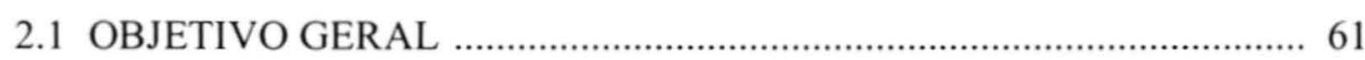

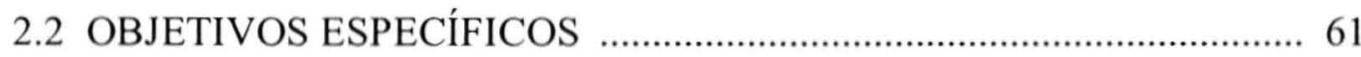

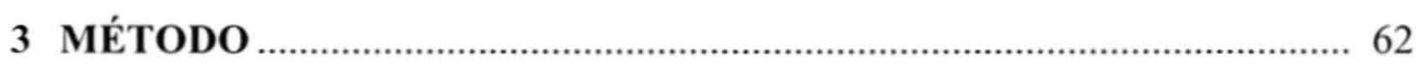

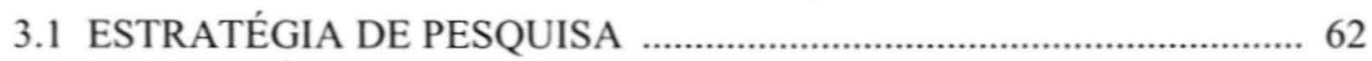

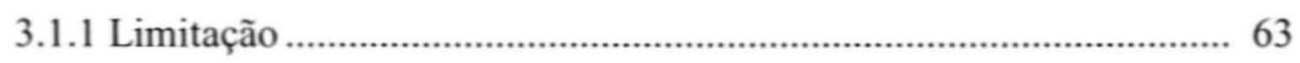

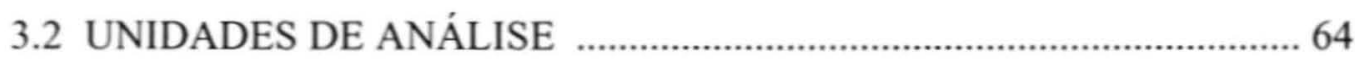

3.3 TÉCNICAS PARA COLETA DE DADOS …………………………….... 71

3.4 ESTUDO DE CAMPO E ASPECTOS RELEVANTES ……………….... 72

3.4.1 Entrevista semidiretiva ……………………………………….... 72

3.4.2 Pesquisa Documental..................................................................... 74

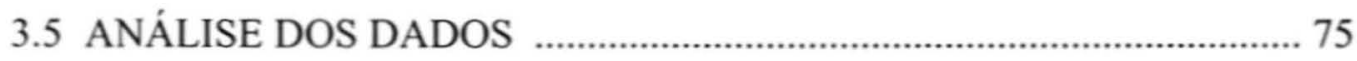

3.6 PRINCÍPIOS ÉTICOS ........................................................................ 75

4 ANÁLISE E DISCUSSÃO DOS RESULTADOS ……………………........ 77

4.1 PERFIL DAS ORGANIZAÇÕES ESTUDADAS ……………………....... 77

4.2 PERFIL DOS PARTICIPANTES ……………………………………....... 80

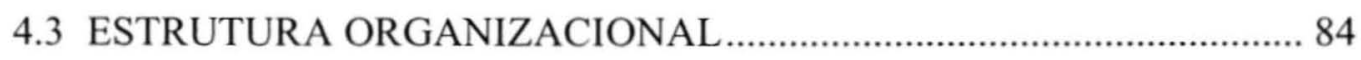

4.3.1 Formalidade no organograma quanto à Logística …………………... 84

4.3.2 Nivel hierárquico ............................................................................ 86 
4.4 ESTRATÉGIA DA LOGÍSTICA ….................................................. 88

4.4.1 Logística e Vantagem Competitiva ............................................. 92

4.4.2 Evolução da função logística ......................................................... 94

4.4.3 Estratégia de Suprimentos ............................................................. 97

4.4.3.1 Relacionamento e Integração com os Fornecedores .............100

4.4.3.2 E-procurement ...................................................................103

4.4.3.3 Avaliação dos Fornecedores …….....................................105

4.4.4 Interface dos profissionais de saúde na demanda de suprimentos ...107

4.5 DISTRIBUIÇÃO E POSICIONAMENTO LOGÍSTICO .........................109

4.5.1 Canal de Distribuição e Distribuição Física ....................................109

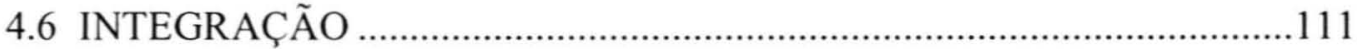

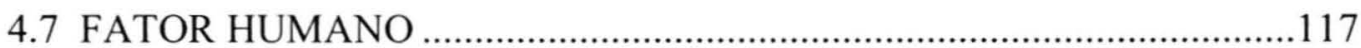

4.8 LOGÍSTICA ENXUTA NO AMBIENTE HOSPITALAR .......................122

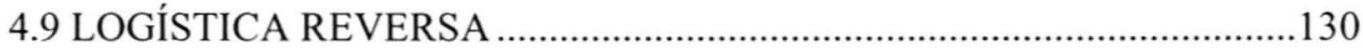

4.10 DESEMPENHO LOGÍSTICO HOSPITALAR ........................................132

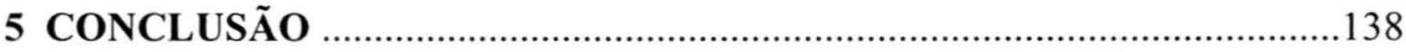

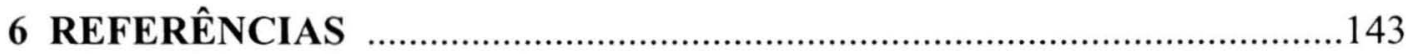

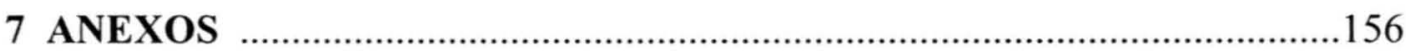

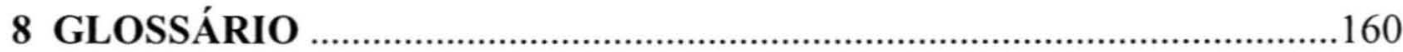




\section{Lista de Figuras}

Figura 1 - A Logística e o valor para o cliente .................................................... 44

Figura 2 - O novo paradigma da logística.......................................................... 46

Figura 3 - Sistema Logístico de Suprimentos na Organização Hospitalar ........... 51

\section{Lista de Quadros}

Quadro 1 - Perfil Social dos Participantes ......................................................... 81

Quadro 2 - Formação Acadêmica, Tempo de Trabalho no Hospital,

Tempo de Trabalho no Cargo Atual e Área de Atuação ....................................... 83

Quadro 3 - Objetivos da Logística e estratégia da Organização .......................... 89

Quadro 4 - Visão e Missão das Organizações ................................................... 92

Quadro 5 - Percepções sobre a interface dos profissionais em suprimentos

segundo natureza da organização ....................................................................108

Quadro 6 - Distribuição Interna ........................................................................110 


\section{Lista de Tabelas}

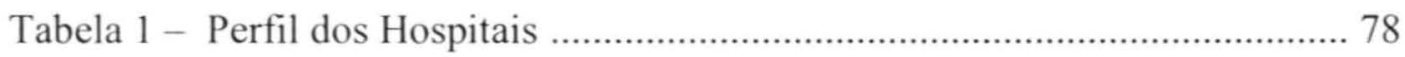

Tabela 2 - Faixa de Faturamento ................................................................... 79

Tabela 3 - Faixa do Patrimônio Líquido ……............................................... 80

Tabela 4 - Formalidade no organograma ……............................................... 84

Tabela 5 - As atividades de logística estão subordinadas à diretoria .................. 87

Tabela 6 - Compreensão da logística como estratégica de vantagem

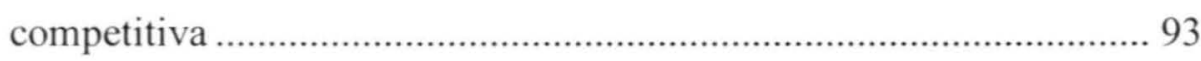

Tabela 7 - Foco principal em estoque, armazenagem e processamento

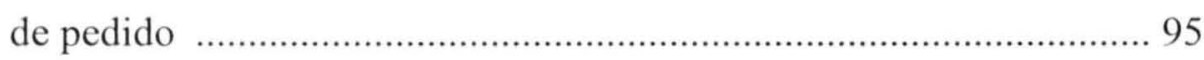

Tabela 8 - Logística utilizada de forma estratégica e integrada em todos os setores do Hospital .......................................................... 96

Tabela 9 - Visibilidade do Hospital quanto sua participação na Cadeia de Suprimentos. 97

Tabela 10 - Falta medicamentos e materiais hospitalares ................................. 98

Tabela 11- Suspensão de cirurgias por falta medicamentos e materiais .............. 99

Tabela 12 - Houve significativa redução dos fornecedores .................................101

Tabela 13 - Compras eletrônicas representam mais de $80 \%$ das aquisições mensais

Tabela 14 - Os fornecedores são avaliados sistematicamente 105

Tabela 15 - Integração plena no planejamento e na execução das atividades logísticas no hospital

Tabela 16 - Materiais e Medicamentos de cada clínica integrados ao planejamento e controle da gestão de suprimentos

Tabela 17 - O fluxo financeiro e de materiais são perfeitamente integrados

Tabela 18 - Fluxo de informação tem permitido agilidade nos processos, redução de estoques e de custos 116

Tabela 19 - A organização promove o aprendizado e troca de experiência entre seus colaboradores 
Tabela 20 - Os profissionais encontram ambiente favorável para

o autodesenvolvimento

Tabela 21 - Financiamento para capacitação/qualificação em logística.

Tabela 22 - Investimento em capacitação/qualificação nas diversas áreas, técnicas e administrativas

Tabela 23 - Níveis de estoque baixos em todos os setores

Tabela 24 - Filosofia just-in-time e compressão de prazos

Tabela 25 - Logística aplicada com enfoque sistêmico e não há desperdício de medicamentos e materiais

Tabela 26 - Logística enxuta e valor ao cliente

Tabela 27 - Mentalidade enxuta dos gestores e adoção de técnicas de favorecimento à otimização do tempo e dos recursos

Tabela 28 - Participação dos comitês e grupos de trabalho na integração dos fluxos logísticos

Tabela 29 - Sistematização do uso, reuso e reciclagem

Tabela 30 - Processo de planejamento de suprimento formalizado, objetivos e diretrizes alinhadas, resultados monitorados e compartilhados

Tabela 31 - Desempenho logístico é avaliado sistematicamente 


\section{Siglas Utilizadas}

ANS - Agência Nacional de Saúde

BEC - Bolsa Eletrônica de Compra

BNDES - Banco Nacional de Desenvolvimento Econômico e Social

CEME - Central de Medicamentos

CEPE - Centro de Estudos e Pesquisa

CLM - Council of Logistics Management

ECR - Efficient Customer Response

FAJ - Fundação Adib Jatene

FAS - Fundo de Apoio e Desenvolvimento Saúde

FMUSP - Faculdade de Medicina da Universidade de São Paulo

IAP's - Institutos de Aposentadoria e Pensões

ICDP - Instituto de Cardiologia Dante Pazzanese

ICHC - Instituto Central do Hospital das Clínicas

INAMPS - Instituto Nacional de Assistência Médica e Previdência Social

INPS - Instituto Nacional de Previdência Social

JCI - Joint Comission International

HC - Hospital das Clínicas

HCFMUSP - Hospital das Clínicas da Faculdade de Medicina da Universidade de

São Paulo

HE - Hospital de Ensino

HIAE - Hospital Israelense Albert Einstein

HSL - Hospital Sírio Libanês

JIT - Just-in-time 
OCDE - Organização para a Cooperação e Desenvolvimento Econômico OMS - Organização Mundial de Saúde OPAS - Organização Pan-Americana de Saúde OPME - Órteses Próteses e Materiais Especiais PPA - Plano de Pronta Ação QR - Quick Response

SADT - Serviço Auxiliar Diagnóstico e Terapia SBIBAE - Sociedade Beneficente Israelita Brasileira Albert Einstein SCM - Supply Chain Management

SINPAS - Sistema Nacional de Previdência Social SPDM - Sociedade Paulista para o Desenvolvimento da Medicina SUS - Sistema Único de Saúde UTI - Unidade de Terapia Intensiva 


\section{INTRODUÇÃO}

A economia mundial está passando por grande transformação com a globalização. Muitas barreiras antes existentes estão caindo e, praticamente, já não há fronteiras a serem alcançadas. A formação dos blocos econômicos mostra a necessidade da união dos países em busca de melhor desenvolvimento e manutenção de suas economias.

Em virtude da globalização, diversos reflexos se manifestam em vários segmentos industriais e de serviços; desde o aumento da competitividade ao acesso às diversas tecnologias. A velocidade com que acontecem as mudanças no mundo atual obriga as organizações a desenvolverem capacidades estratégicas para antecipar as mudanças e adequarem-se a elas. O cliente final também modificou, estando cada vez mais exigente e mais bem informado na hora de adquirir bens e serviços.

$\mathrm{Na}$ área da saúde não tem sido diferente; os pacientes dispõem de informações e canais de participação múltiplos, e embora não seja a maioria que tenha acesso, estão mais informados do que há alguns anos. Essa nova realidade tem permitido, em muitos municípios, que o paciente tome, enquanto sujeito participativo, decisões junto ao profissional de saúde de como será o plano de tratamento de sua saúde. Os meios de comunicação, incluindo a internet, têm sido componentes importantes desse processo.

Um dos setores que apresenta grande velocidade de mudanças é o da saúde. A incorporação de tecnologias de ponta e a disponibilidade de recursos de maior custo, ao lado do aumento da demanda, impactam no comportamento das organizações de saúde, que necessitam desenvolver a capacidade de adaptar-se às alterações do setor (SHORTELL e KALUZNY, 2000). 
Nesse novo cenário, a velocidade e a globalidade dos processos de mudança do mundo atual obrigam as organizações, incluindo as de saúde, a desenvolver novas formas de relação à sua volta (parcerias) e novas modalidades de gestão, incluindo a possibilidade de novos modelos organizativos, que lhes permita dar respostas satisfatórias às atuais necessidades da população.

Uma das atividades úteis nesse processo e que vêm sendo transformada radicalmente é a de logística, que, de parte acessória e complementar ao processo produtivo, passa a inserir-se como fundamental no posicionamento estratégico das organizações, tendo em vista o processo de criação de valor e atendimento das necessidades dos clientes, cada vez mais exigentes em termos de prazos, preços e serviços.

Segundo BITTAR (1996), a logística para planejamento e implementação das formas de atendimento em saúde é fundamental para a obtenção de sucesso. Entre essas formas, a necessidade de forte componente administrativo evita imediatismos e improvisação.

Até os anos 1950 é considerada fase dos anos adormecidos da logística. Em breve histórico, na década de 1940 a logística limitava-se às questões de transportes da produção agrícola (FIGUEIREDO e ARKADER, 2000) e até 1960 sofre influência militar, com a preocupação voltada para a identificação dos principais aspectos da eficiência no fluxo de materiais, em especial às questões de armazenamento e transporte, no contexto da distribuição física.

No início da década de 1970 aconteceu a crise do petróleo, que teve como consequência o encarecimento súbito nos preços dos transportes e deu-se início a uma nova visão integrada das questões logísticas, na busca inicial de racionalização integrada.

O desenvolvimento da informática, por sua vez, possibilitou a integração mais dinâmica na cadeia de suprimentos. A disponibilização de sistemas que 
permitem o intercâmbio eletrônico de dados com fornecedores e clientes, a introdução do código de barras, entre outros, marca uma nova fase de integração, em que a maior preocupação é a satisfação do cliente, entendendo como tal não somente o cliente final, como também todos os elementos intermediários que são clientes dos fornecedores.

O campo da logística, de um tratamento mais restrito voltado para a distribuição física de materiais e de bens considerados de cunho secundário, volta-se para um escopo mais abrangente, que integra os esforços da organização aos dos seus fornecedores e distribuidores e considera a cadeia como um todo nas atividades de compras, administração de materiais e distribuição, representando, de fato, uma área de integração de distintos enfoques. (FIGUEIREDO e ARKADER, 2000; NOVAES, 2007; CHRISTOPHER, 1997). Essa nova abordagem logística é chamada Supply Chain Management (SCM) ou, em português, Gerenciamento da Cadeia de Suprimento (GCS). ${ }^{1}$

Dos vários conceitos de GCS apresentados no item 1.2 deste capitulo, a nova abordagem significa neste estudo uma forma integrada de planejamento e controle do fluxo de materiais, informações e recursos em gestão de saúde. Essa abordagem exige visão e administração sinérgica de todos os participantes da cadeia de valor, visando agregar valor ao cliente final em cada elo da cadeia gerando vantagens competitivas sustentáveis ao longo do tempo, tendo como foco central o cliente, defendido aqui como a pessoa do paciente.

\footnotetext{
${ }^{1}$ Todo setor apresenta uma forma de linguagem própria, a área da logistica no atual mundo organizacional é carregada de muitos termos em inglês. Neste estudo optou-se por descrever o termo em inglês, traduzi-lo e a seguir utilizar-se o termo em português ou a cada aparecimento em inglês é expressa a respectiva tradução entre parênteses.
} 
Acredita-se que a complexidade do sistema de saúde está a exigir uma gestão que aplique técnicas de logística em serviços de saúde e conceitos de serviço enxuto como agilização dos fluxos, otimização dos recursos, redução de lead time ( tempo compreendido entre a primeira atividade até a última de um processo de várias atividades) em diversas áreas nos hospitais. É esta forma de gestão que gera o adequado tratamento do estado de doente para o desejado estado de saúde da pessoa enferma passa pelo atendimento em serviços de saúde, por hospitalização, intervenção cirúrgica ou outro procedimento de natureza médico-hospitalar.

Nesse contexto, é vital o perfeito funcionamento da infra-estrutura de instalações, tecnologia, fluxos, materiais, equipamentos e instrumentais médicohospitalares, na hora e lugar certos, para que possam ser prestados os necessários serviços de saúde aos pacientes, lembrando que a saúde é um bem intangível, mas só se percebem sua importância e valor com mais clareza quando o equilíbrio na dinâmica saúde-doença é afetado; vincula-se diretamente à capacidade que os indivíduos têm em manter sua sobrevivência e continuidade da espécie.

A Organização Mundial de Saúde traz que "Saúde não é apenas ausência de doenças, mas um estado de completo bem-estar físico, social e mental". O direito à saúde tem como fundamento o direito à vida, e à vida em sua plenitude. É o direito ao bem estar, enfim, direito a ser feliz.

Esta tem sido uma das questões centrais tratadas mundialmente no campo da saúde, dadas as mudanças que vêm ocorrendo em praticamente todas as dimensões de sua análise, incluindo o referencial de saúde em sentido mais amplo, como componente e instrumento da qualidade de vida e bem-estar; o de sua determinação não apenas biológica e individual, mas como um complexo processo saúde/doença que representa uma expressão particular do processo social em geral, o que leva a considerá-lo como a produção social da saúde ou da doença; o de sua inserção no campo das políticas públicas e, ainda, entre outras, na redefinição da própria concepção, organização e funcionamento dos sistemas e serviços de saúde. 
Entende-se que na contemporaneidade o controle dos materiais e insumos, nas formas de comprar e processar pedidos, e a adesão à prática de padronização e a utilização do just-in-time possibilitam ao estabelecimento de saúde evitar desperdícios e perdas. A logística moderna procura também eliminar tudo que não tem valor para o cliente, ou seja, tudo que acarreta somente custos e perda de tempo. Esforçando-se para que a falta ou a escassez de insumos tem representado para o hospital um problema sério e as carências de insumos essenciais coexistem com excessos de insumos não-essenciais, refletidos em inventários sem movimentos ou obsolescência (OPAS, 2004).

É nesse sentido que nesta tese estuda-se a logística em serviços de saúde, especificamente a cadeia de suprimentos em cinco hospitais do município de São Paulo/SP, públicos e privados.

Sendo o Sistema Único de Saúde (SUS) - gigante em produção de serviços de saúde - BITTAR (2006, p.38-39) cita que
é surpreendente que com tantos Programas, Serviços, Ações, Procedimentos, enfim, um volume de produtos enorme, não se tenha no seu planejamento estratégias de logistica que contemplem áreas de infra-estrutura, ambulatório/emergência, complementar de diagnóstico e terapêtica, internação clínico-cirúrgica e assistência extra-hospitalar.

MALIK (2004) reforça a idéia de BITTAR (2006) ao afirmar que há um problema bastante comum quando se olha para os serviços de saúde: os meios para trabalhar de maneira adequada, quais sejam a área física, os insumos ou suprimentos, logística, e, também, diretrizes, protocolos ou desenhos de modelos de assistência, que afetam técnicos, administradores, usuários e até os pesquisadores. 
A autora acima acrescenta, ainda, que nas revistas voltadas para saúde coletiva quase não há publicações referentes à gestão de suprimentos ou supply chain management (SCM), mais frequente em textos da área administrativa, raramente direcionados para serviços de saúde. A autora também afirma que os artigos, quando aparecem nas revistas de saúde, têm muito mais tom de denúncia ou propaganda do que de experimentação de novos modelos, situando-se sob a grande denominação de artigos de opinião.

É inegável a necessidade de melhorias no setor de saúde. Para alguns autores a crise nos hospitais advém de baixos investimentos ao longo dos últimos anos, e do subfinanciamento do custeio e das formas de gestão, consideradas muito tradicionais. Outro questionamento é a economia de escala ao mostrar uma rede hospitalar fortemente marcada pela presença de pequenos hospitais (MENDES, 2002; COVELLO, 2003; TONELLO e MARTINHO, 2003).

A logística de hoje, nos conceitos do gerenciamento da cadeia de suprimento, não trata somente das operações logísticas clássicas, mas passa a ser eminentemente estratégica, atuando fortemente na concepção, planejamento, implementação e execução dos projetos estratégicos nas organizações (NOVAES, 2007. CHING (2001) afirma que é muito importante as organizações repensarem seu sistema logístico, pois se trata de um fator fundamental para que alcancem sucesso.

A assistência hospitalar como integrante dos serviços de saúde, a evolução dos conceitos de logística e cadeia de suprimentos, o conceito de mentalidade enxuta, e logística nos serviços de saúde são explorados nos itens a seguir. 


\subsection{SERVIÇOS DE SAÚDE E ASSISTÊNCIA HOSPITALAR}

Atualmente, os serviços estão no centro da atividade econômica de qualquer sociedade. Segundo MARRIOTT (2002), vive-se a Era dos Serviços, a transição de uma economia baseada na produção para uma economia baseada no serviço.

FITZSIMMONS (2000) entende que o setor de serviços é responsável por mais de $75 \%$ dos empregos nos Estados Unidos, dando continuidade a uma tendência que começou há mais de um século. Hoje, com base no número de empregos, não se pode mais caracterizar os Estados Unidos como uma sociedade industrial, trata-se de uma sociedade pós-industrial, ou de uma sociedade de serviços.

As organizações de serviços de saúde, neste estudo as hospitalares, diferem de outros tipos de setores produtivos em vários aspectos: estrutura de pessoal, lida com o tema vida e morte, estrutura de financiamento e de propriedade peculiares, submissão às atividades de regulação e acreditação, uso extensivo de tecnologia e conhecimento, custos altos e crescentes e relacionamentos específicos com clientes, fornecedores, funcionários, comunidades e outros (LORENZI e RILEY, 1995).

A característica que diferencia o hospital do contexto das empresas de serviços é a natureza do seu trabalho. O trabalho dirigido a aliviar o sofrimento e a preservar a saúde e a vida é dificil de ser contextualizado como área de negócio ou indústria, para cidadãos, políticos e profissionais do setor saúde (OPAS/OMS, 2004).

Na área da saúde, a história do desenvolvimento dos serviços o hospital, em seu início, representava um local primitivo, cercado pelo misticismo, pelo sobrenatural e pela morte. Era visto como único refúgio para o doente desprovido de 
recursos ou como um instrumento de exclusão de indivíduos que traziam algum perigo à saúde da população (FOUCAULT, 1992).

As primeiras raízes de estabelecimentos hospitalares são encontradas em duas das mais antigas civilizações: a Índia e o Egito (Repartição Sanitária PanAmericana - Escritório Regional da Organização Mundial da Saúde - OMS, 1952).

Em ordem cronológica, LISBOA (2002) traz que vários autores indicam a existência de hospitais: anexos aos mosteiros budistas, em 543 a.C. (Puech); e existentes no Ceilão, entre os anos 437 e 137 a.C. (Garrison).

Vários hospitais mantidos em diferentes lugares, eram providos de dieta conveniente e de medicamentos para os enfermos, preparados por médicos, por Dutha Gamoni, em 161 a.C (Robinson); 18 hospitais, providos pelo rei Gamari, no Ceilão, em 61 a.C. (Puech). Da mesma forma, aparecem as primeiras referências a enfermeiros, geralmente estudantes de medicina: eles deveriam demonstrar asseio, habilidade, inteligência, conhecimento da arte culinária e de preparo de medicamentos. Moralmente deveriam ser dedicados e cooperadores (Paixão, 1960).

Segundo MONTEIRO FILHO (1972), no ano 400, surgiu em Roma, o primeiro hospital com a finalidade de atender aos necessitados, seguido por outros, como o Hospital Hotel Dieu, em Paris, entre os anos 641 a 669, o Hospital de Milão, no ano 77, o Hospital Santo Albano, na Inglaterra, no ano 794.

A organização dos serviços de saúde sofreu, através dos tempos, a influência dos conceitos religiosos políticos e sociais de cada época e foi-se concretizando para dar resposta ao aparecimento das doenças.

Na Idade Média surgiram os primeiros hospitais do mundo ocidental; mais propriamente hospícios, ou asilos, nos quais os pacientes recebiam se não o tratamento adequado, pelo menos mais conforto espiritual (SCLIAR, 1987). No final da Idade Média a situação começou a mudar: a fundação e o desenvolvimento das universidades, a descoberta da imprensa e do microscópio e a intensificação do 
tráfego entre as nações foram fatos marcantes para o desenvolvimento do conhecimento médico.

No entanto, as condições higiênicas continuavam no mesmo passo; o hospital ainda era visto como uma sentença de morte (FOUCAULT, 1992), como um depósito de doentes cuidados por religiosos e para mortes piedosas (SCLIAR, 1987).

Com o advento da revolução industrial houve grande êxodo das populações para áreas urbanas e a busca por soluções dos problemas de saúde pública, gerados pela urbanização, resultou em grandes avanços nas ciências médicas, propiciando a profissionalização dos hospitais que passaram a ser local para cura de doenças e não simplesmente um abrigo. A responsabilidade pela assistência aos doentes passou para o Estado, e, à semelhança do que ocorre nas fábricas, no exército e nas escolas, uma nova disciplina foi introduzida; não a dos agrupamentos isolados (legiões urbanas, mosteiros medievais), mas a que rege a sociedade como um todo (SCLIAR, 1987).

Cabe lembrar também do atendimento domiciliar na história do desenvolvimento dos cuidados à saúde. O médico inicialmente atendia seus pacientes a domicilio, freqüentava a casa das pessoas, convivendo com todos os momentos significativos da vida familiar (doenças, casamentos, nascimentos, conflitos), compartilhando seus segredos. Isto teve especial importância no final do século XIX e início do século XX, quando os recursos terapêuticos eram limitados, e colocar a pessoa doente na cama era o tratamento mais utilizado. Diante desta realidade de escassos recursos terapêuticos, os antigos médicos de família, sentavam à beira da cama dos doentes, ouvindo, apoiando e ajudando-os a enfrentar as dificuldades.

No Brasil, a estrutura médico-hospitalar tem suas origens logo após o descobrimento, na fundação da primeira Santa Casa de Misericórdia de Santos, na 
capitania de São Vicente, em 1543. Desde aquela época até o final do século XIX, o papel dos hospitais era o de tratar enfermos sem moradia ou condições sociais para serem atendidos em casa. Os hospitais eram destinados aos pacientes que não tinham recursos ou que necessitavam de algum tipo de isolamento (COHN e ELIAS, 1996).

Dessa forma, a assistência ao doente no Brasil surgiu com a formação das primeiras Irmandades: a de São Vicente em 1532, Salvador em 1549 e Rio de Janeiro em 1565, com base no Regimento das Capelas e dos Hospitais, de 1514, publicado por D. Manoel. Em Portugal, fruto ímpar da Renascença, o modelo assistencial foi aquele decretado pelo Regimento, em razão do que a criação das primeiras vilas se fazia acompanhar das instituições das respectivas Misericórdias (LUSSARI, 2003).

Paralelas ao processo de industrialização do país surgiram as correntes imigratórias; graças a elas os hospitais comunitários beneficentes foram sendo construídos a fim de suprirem as necessidades médicas das coletividades estrangeiras que os fundaram e, gradativamente, passaram a atender também parte da população (BRANDT, 1998). No município de São Paulo têm-se, como exemplos, os hospitais Beneficência Portuguesa, em 1859; o Samaritano, em 1890; o Alemão Oswaldo Cruz, em 1897; o Santa Catarina, em 1903; o Sírio Libanês, em 1921; o Santa Cruz, em 1939 e o israelita Albert Einstein, em 1955 (BRANDT, 1998).

Em relação aos serviços de saúde no Brasil existiam dois projetos em separado: um para atender problemas de natureza coletiva e que não considerava a assistência médica individual como sua atribuição, salvo no caso dos sanatórios para doenças infecciosas e mentais; e outro, para reparar a saúde dos trabalhadores inseridos no mercado formal de trabalho. Grande parcela da população ficava sem qualquer tipo de atendimento devido à insuficiência dos esquemas caritativos como das Santas Casas de Misericórdia. Essas duas tradições viram-se reforçadas ideologicamente pela influencia da medicina liberal da corrente norte-americana. A partir de 1918, vários médicos foram à América do Norte imbuídos para especializarem-se em higiene e saúde pública (LABRA, 2001). 
Alguns autores (ALMEIDA e CASTRO, 1999; MOLINA, 1998) afirmam que até os anos 1930, do século XX, não havia no país uma política de saúde propriamente dita. A atuação do governo central no setor limitava-se à implantação de instituições, tais como hospícios, asilos para tuberculosos ou hansenianos, além da implementação de serviços de saúde pública, em nível nacional, baseados no modelo das "campanhas sanitárias". O desenvolvimento da política de saúde do país confunde-se com a evolução da Previdência Social, mais especificamente ao subsetor médico assistencial (COHN e ELIAS, 1996).

O decreto n`. 4682 de 24 de janeiro de 1923, conhecido como "Lei Elói Chaves", é considerado marco inicial do processo de criação da assistência médica organizada no Brasil. Essa lei institucionalizou a previdência através das Caixas de Aposentadorias e Pensões (CAPs), dos trabalhadores do setor ferroviário brasileiro. Vale destacar que, até então, a previdência existente era incipiente e restrita a alguns setores do serviço público federal; mesmo nesse âmbito, em algumas situações os decretos de criação dos montepios nunca se efetivaram.

Dentre as atribuições iniciais das CAPs, duas dizem respeito à prestação de serviços de saúde: o atendimento médico de emergência para o segurado e sua família, e a concessão de subsídios para a compra de medicamentos. Em 1926, as atribuições das CAPs foram ampliadas e passaram a incluir as internações hospitalares em casos de intervenções cirúrgicas.

A assistência médica prestada pelas CAPs era, em grande parte, contratada de terceiros, embora aquelas de maior porte tivessem construído estruturas próprias de atendimento, que variavam de ambulatórios a hospitais. No sistema CAPs de assistência à saúde, o paciente não escolhia o prestador de serviço, mas também não pagava pelo atendimento. Os prestadores de serviços eram médicos, clínicas e hospitais contratados e pagos pela CAPs, que funcionava nos moldes de uma seguradora. 
Em 1923, as ações de saúde pública foram vinculadas ao Ministério da Justiça; constituía responsabilidade do Estado o controle de doenças endêmicas e epidemias. Em 1930, a responsabilidade passou ao Ministério da Educação e surgiram muitos sanatórios para tratamentos de Tuberculose e Hanseníase, que se associavam aos manicômios públicos existentes.

Com o Estado Novo, de Getúlio Vargas, surge o seguro social e teve início a implantação dos Institutos de Aposentadoria e Pensões (IAP's), divididos segundo categorias profissionais (industriários, comerciários, marítimos, bancários) e vários setores da atividade econômica. Os recursos financeiros passaram a ser tripartite (Estado, Empresa e Trabalhadores) e centralizados na esfera federal. O período de 1930 a 1943 foi marcado por legislações trabalhistas, regulação de políticas de saúde e educação e apontado como ponto de partida do Welfare no Brasil; considerados o conjunto de transformações do Estado brasileiro e as formas de regulação social (KAMIMURA e MOLINA, 2004).

Em relação à assistência hospitalar foram construídos hospitais de grande porte em alguns Estados da Federação. No município de São Paulo, em 1938, iniciou-se a construção do maior centro hospitalar do Brasil, o Hospital das Clínicas da Faculdade de Medicina da Universidade de São Paulo.

Somente em 1953 foi criado o Ministério da Saúde, com a Lei nº 1.920, que desdobrou o então Ministério da Educação e Saúde em dois ministérios: Saúde e Educação e Cultura, e, progressivamente, na saúde, iniciou-se o processo de alteração do modelo voltado a campanhas verticais e de estilo repressivo, realizadas pelo Exército, no combate e controle de doenças, dando lugar ao crescimento da atenção médica da Previdência Social.

Em 1967, com a junção dos IAP's, foi criado o Instituto Nacional de Previdência Social (INPS), que trouxe ampliação da cobertura previdenciária. Em 1974, ocorrem mudanças na estrutura existente com a separação da área de trabalho da área da previdência e foi criado o Ministério da Previdência e Assistência Social. 
A década de 1970 foi marcada por grande incentivo do governo aos prestadores privados de assistência médica (MENDES, 1993). Em 1974, implantouse o Plano de Pronta Ação (PPA), modificando a relação de compra entre a Previdência Social e seus prestadores ao instituir o pagamento por serviços prestados ou convênio por subsídio fixo. O PPA contribuiu para a ampliação da cobertura da população não assegurada e ao financiamento do sistema privado por meio de recursos públicos. Segundo MENDES (1993), estendeu o atendimento de urgência a toda população e em ações combinadas com o Fundo de Apoio e Desenvolvimento Social (FAS) abriu um mercado cativo para o setor privado, em especial o setor hospitalar.

Em 1977 e 1978 foram criados o Sistema Nacional de Previdência Social (SINPAS) e o Instituto Nacional de Assistência Médica e Previdência Social (INAMPS), destinando-se o primeiro às atividades finalísticas e o segundo à coordenação das atividades médicas. Foram criados, também, institutos e órgãos, como o DATAPREV - empresa de processamento de dados para controle e avaliação dos serviços prestados, e o CEME - Central de Medicamentos.

GONÇALVES (1983) aponta que a evolução do conhecimento e as novas possibilidades terapêuticas, surgidas ao longo dos séculos XVIII e XIX transformaram o hospital em um centro de tratamento de doentes, principalmente daqueles que precisavam de intervenções cirúrgicas, o que fez desaparecer o caráter de abrigo filantrópico. O autor identifica diferentes funções para o hospital: a internação de pacientes, as ações de natureza preventiva, a participação em programas comunitários e a integração no sistema de saúde. Essas funções o caracterizam como uma organização complexa que necessita gerenciar inúmeras atividades-meio relacionadas aos serviços de apoio (manutenção, lavanderia, nutrição dietética, alimentação), aos recursos financeiros, aos recursos tecnológicos e materiais, ao sistema de informações e logístico, e à infra-estrutura. De acordo com MIRSHAWAKA (1994, p. 22): “de todas as empresas modernas, nenhuma é mais complexa do que o hospital". 
Para CASTELAR (1995), a finalidade do hospital nos dias atuais está direcionada para a maior resolução da doença, agilizando o diagnóstico e tratamento para reduzir a permanência dos pacientes, pois à medida que o hospital evolui tecnologicamente e recicla seus recursos humanos aumentam os custos desses recursos, tornando cada vez mais inviável, do ponto de vista financeiro, internações por períodos prolongados.

O Ministério da Saúde do Brasil define o hospital moderno como:

Parte integrante de uma organização médica e social, cuja função básica consiste em proporcionar à população assistência médica integral, curativa e preventiva, sob quaisquer regimes de atendimento, inclusive domiciliar, constituindo-se também em centro de educação, capacitação de recursos humanos e de pesquisa em saúde, bem como de encaminhamento de pacientes, cabendo-lhe supervisionar e orientar estabelecimentos de saúde a eles vinculados tecnicamente (BRASIL, 2001).

Atualmente o hospital é uma instituição onde atividades intelectuais são mescladas com ciência e tecnologia, elementos sociais, culturais e educacionais, resultando em procedimentos utilizados por seres humanos em seres humanos (BITTAR, 1997).

Dentre os serviços que incumbem aos órgãos e entidades que compõem o Sistema Único de Saúde brasileiro estão os serviços hospitalares, e o hospital é um componente fundamental na rede de serviços, no contexto de cadeia produtiva de saúde. Os hospitais se apresentam, atualmente, como a organização mais complexa que participa da prestação de serviços de saúde. Suas funções vêm passando por mudanças na medida em que o modelo assistencial altera o equilíbrio entre a atenção de pacientes hospitalizados e a atenção ambulatorial, e o hospital passa a se tornar parte integrante de uma rede de serviços. 


\subsubsection{Caracterização dos Hospitais}

O termo hospital originou-se do latim hospitalis, palavra derivada de hospes, que se refere à hóspede, estrangeiro, viajante, aquele que hospeda. No início da era cristã a terminologia mais utilizada relacionava-se com o grego e o latim, nosocomium, lugar dos doentes, asilo dos enfermos; nosodochium, que significa recepção de doentes; hospitum, que designava os estabelecimentos que recebiam ou eram ocupados permanentemente por enfermos pobres, incuráveis ou insanos, e hospital, para os locais reservados para tratamento temporário dos doentes (OLIVEIRA, 1996).

Segundo NOVAES e MOTTA (1996), as instituições hospitalares, como prestadoras de serviços de alta relevância social, devem estar atentas ao desenvolvimento tecnológico, não só para as adaptações temporárias, fruto de circunstâncias favoráveis, mas também, e principalmente, para ações gerenciais estratégicas de grande alcance. É necessária a atenção gerencial permanente para inovar e usar o máximo de conhecimentos na melhoria da eficiência e eficácia da prestação de serviços.

Os hospitais, segundo CAMPOS (in GONÇALVES e ACHÉ, 1999; COSTA NETO e AZEVEDO, 1986; CAVALLINI, 2002) podem ser caracterizados quanto aos aspectos: natureza jurídica, capacidade de lotação, natureza da assistência, nível de atenção da assistência e corpo clínico.

- Natureza Jurídica: os hospitais classificam-se em público e privado. O público integra o patrimônio Federal, Estadual e Municipal, autarquias e fundações instituídas pelo poder público. O privado filantrópico reserva para a população carente, conforme legislação, serviços gratuitos e não remunera sua diretoria e os lucros são revertidos para a manutenção da instituição. O privado, 
com fins lucrativos, presta serviços para auferir resultados financeiros lucrativos. O privado sem fins lucrativos, beneficente, é fundado e mantido por contribuições e doações, presta serviços principalmente para seus associados. A diretoria não é remunerada e os lucros auferidos são revertidos para manutenção e desenvolvimento da instituição.

- Capacidade de Lotação: são classificados em pequeno porte (até 50 leitos); médio porte (de 50 a 150 leitos); grande (de 151 a 500 leitos) e; extra ou especial (acima de 500 leitos).

- Natureza da Assistência: são classificados em geral, por prestar assistência aos pacientes portadores de doenças das especialidades básicas (clínica médica, clínica ginecológica e obstétrica e clínica pediátrica); geral com especialidades, por prestar, além das básicas, assistência aos pacientes portadores de doenças de várias especialidades; e especializado, por prestar assistência aos pacientes portadores de doenças específicas ou predominantes.

- Níveis de Atenção: são classificados em secundário, que presta serviços com recursos básicos de diagnósticos (laboratório de análises clínicas, radiologia, eletrocardiografia. Possui leitos para áreas básicas da medicina, ou seja, clínica médica, cirurgia geral, clínica ginecológica e obstétrica e clínica pediátrica). Terciário, em que os cuidados prestados são prestados em hospitais gerais, contemplados com várias especialidades e que se destinam também ao ensino) e; quaternário ou especializado mais complexo (cuidados prestados em hospitais especializados, onde o desenvolvimento da pesquisa e o avanço tecnológico os destacam no país). 
- Corpo Clínico: é classificado em fechado, que presta assistência por meio de um corpo clínico próprio-efetivo; aberto quando não dispõe de um corpo clinico efetivo e qualquer médico pode utilizar as instalações para prestar assistência aos seus pacientes; e misto, que associa as duas formas descritas).

- Sistema de edificação: classifica-se em pavilhonar, que possui várias edificações de pequeno porte podendo ou não estar interligados; monobloco, possuem serviços concentrados em um único bloco; multibloco, serviços distribuídos por edificações de médio ou grande porte, interligadas ou não; horizontal, predominância da dimensão horizontal e vertical, predominância da dimensão vertical.,

Os indicadores de níveis de hierarquia do Cadastro Nacional de Estabelecimentos de Saúde (CNES), criado através da Portaria MS/SAS n 376/2000 (BRASIL, 2000), com a finalidade de estabelecer código único de acesso ao Banco de Dados Nacional dos Estabelecimentos de Saúde, para os diversos Sistemas de Informações, classifica o tipo de atendimento das instituições de saúde conforme complexidade em 8 categorias: Nível 1 - estabelecimento de saúde ambulatorial que realiza somente Procedimentos de Atenção Básica (PAB) e ou Procedimentos de Atenção Básica Ampliada (PABA) definidos pela NOAS (Norma Operacional de Assistência à Saúde); Nível 2 - estabelecimento de saúde ambulatorial que realiza procedimentos de Média Complexidade definidos pela NOAS como de $1^{\circ}$ nível de referência; Nível 3 - estabelecimento de saúde ambulatorial que realiza procedimentos de média complexidade definido pela NOAS como de $2^{\circ}$ nível de referência (M2) e como de $3^{\circ}$ nível de referência (M3); Nível 4 - estabelecimento de saúde ambulatorial capacitado a realizar procedimentos de alta complexidade definidos pelo Ministério da Saúde; Nível 5 - estabelecimento de saúde que realiza além dos procedimentos previstos nos níveis de hierarquia 1 e 2 , efetua primeiro atendimento hospitalar, em pediatria e clínica médica, partos e outros procedimentos hospitalares de menor complexidade em clínica médica, cirúrgica, pediatria, 
ginecologia e obstetrícia; Nível 6 - estabelecimento de saúde que realiza procedimentos previstos nos níveis de hierarquia 2 e 3 , além de procedimentos hospitalares de média complexidade. Por definição enquadram-se nesta categoria os hospitais especializados; Nível 7 - estabelecimento de saúde que realiza procedimentos de média complexidade. Realiza procedimentos previstos nos níveis de hierarquia 2 e 3 abrangendo procedimentos ambulatoriais de alta complexidade;

Nível 8 - estabelecimento de saúde que realiza procedimentos de alta complexidade no âmbito hospitalar e ambulatorial, em que se enquadram os hospitais pesquisados neste estudo.

\subsubsection{Hospitais: Públicos e Privados}

O sistema de saúde no Brasil, em sua estrutura e funcionamento institucional, apresenta, de um lado, forte participação do setor privado na assistência hospitalar e, de outro, forte participação do setor público na assistência ambulatorial. As entidades privadas de assistência à saúde também participam de forma complementar ao SUS, dando-se preferência, de acordo com diretriz constitucional, às organizações não lucrativas.

No Brasil, os hospitais surgiram no período colonial, com a ação catequizadora dos jesuítas que os implantaram no modelo europeu, caracterizado como instituições religiosas de cuidados aos doentes. Naquela época, o hospital era um local para abrigar pobres e isolar da população as pessoas com doenças contagiosas. As atividades hospitalares eram executadas por pessoas interessadas em praticar boas ações, de cunho caritativo e religioso. Com o tempo, sua função deixou de ter característica religiosa e passou a ser pública, atendendo também às pessoas 
que não tinham condições financeiras de serem tratadas por médicos, em suas casas (CASTELAR, 1995).

Quanto à natureza administrativa, os hospitais são classificados como públicos ou privados. Os públicos são mantidos exclusivamente pelo Estado, em qualquer esfera de Governo; federal, estadual ou municipal, e os privados são mantidos por recursos oriundos dos pagamentos feitos pelos clientes, diretamente, ou por outras fontes provedoras, como seguradoras, cooperativas ou instituições filantrópicas. Geralmente os privados fazem contratos para disponibilizar uma parte de seus leitos para o Sistema Único de Saúde.

Os serviços hospitalares que constituem o SUS são, na sua maioria, privados (cerca de $60 \%$ dos leitos hospitalares). Desde o início da implantação do SUS, os hospitais privados sem fins lucrativos mantiveram-se no topo da lista de volumes de internações apresentados (OPAS, 2004).

Cabe salientar que além destes e dos prestadores de serviços hospitalares públicos municipais, estaduais e federais, os Hospitais de Ensino (HE) são instituições estratégicas para o SUS, desempenhando papel preponderante junto à comunidade, tanto em relação à assistência quanto no desenvolvimento de ensino e pesquisa. Segundo BORGES NETO (2007) os HEs, pelo caráter de referência, concentram os pacientes mais graves, atendimento terciário com ações de média e alta complexidade, que exigem mais recursos e atenção.

A origem do setor privado de serviços de saúde no Brasil está associada à atividade liberal médica e aos hospitais filantrópicos, de ordens religiosas e mutuais. O setor hospitalar seguiu, no país, um padrão parecido com o existente no mundo ocidental; organizou-se, a princípio, em instituições gerenciadas por Ordens Religiosas e financiadas por donativos: as Santas Casas e hospitais religiosos. Com o grande fluxo de imigrantes ocorrido a partir da segunda metade do século XIX até as duas primeiras décadas do século XX, as entidades mutualistas, sem fins lucrativos, que surgiram também mantiveram hospitais, especialmente em grandes centros 
urbanos (ROEMER, 1980; CONFEDERAÇÃO DAS MISERICÓRDIAS DO BRASIL, 1992).

A organização de bases de financiamento provindas do seguro social, a partir dos anos 1930, implicou em um crescimento importante da prestação privada lucrativa de serviços de saúde, seja sob a forma de hospitais e clínicas contratadas por pós-pagamento por serviços produzidos, ou por empresas médicas de prepagamento (BRAGA e PAULA, 1981; CORDEIRO, 1980 e 1984).

Breves foram os períodos em que o seguro social implementou uma política de autosuficiência de oferta hospitalar pelas organizações estatais (LUZ, 1979). MEDICI (1990) também cita que a rede hospitalar privada, na metade dos anos 1950, já era maior do que a pública e financiada, em grande parte, pelo Estado, para além de suas formas originais, assentadas na caridade. Na década de 1960, com a existência de recursos de capital do Fundo de Ação Social/FAS da Caixa Econômica Federal, houve um grande surto de crescimento dos hospitais privados.

Ao abordar hospitais públicos e privados, remete-se à discussão dos modelos e sistemas de saúde que vêm ganhando novos contornos após as diversas reformas que, desde os anos 1990, vêm sendo implementadas nos países europeus e periféricos. No Brasil, optou-se, na Constituição Federal de 1988, por um modelo inspirado nos sistemas nacionais de saúde de acesso universal e integral, quando, na realidade, já existia um setor privado robusto, tanto no campo da prestação de serviços, com um parque hospitalar predominantemente privado, com seguradoras e operadoras de planos privados de saúde que, segundo a Agência Nacional de Saúde (ANS), em dezembro de 2007, contavam com 48,2 milhões de clientes, destes, 9,1 milhões referem-se exclusivamente a odontologia (ANS, 2007).

Segundo UGÁ et al. (2008), a construção do sistema de saúde brasileiro a partir de uma base fortemente privatizada - que era a existente em 1988 - resultou em um modelo absolutamente peculiar, no qual há uma imbricação do estatal e do privado nos principais elementos estruturantes do sistema. $\mathrm{Na}$ formulação da 
Constituição Federal brasileira de 1988 houve embates em relação à denominação do segmento de planos privados e seguros de saúde no Brasil.

Com base na tipologia da Organização para a Cooperação e Desenvolvimento Econômico - OCDE (2004), a definição de suplementar confirma o caráter incremental do seguro em relação ao sistema nacional de saúde brasileiro, constituído pelo Sistema Único de Saúde (SUS), em que o acesso é universal e integral. Entretanto, uma vez consagrado que o segmento de planos e seguros de saúde oferece serviços paralelos aos do SUS - diferenciados apenas em termos de hotelaria e no que tange ao acesso, à maior facilidade para agendar o atendimento e da maior possibilidade de escolher medicamentos não genéricos - verifica-se que, além da função de suplementar os serviços do SUS, o segmento de seguros privados é duplicado quanto à cobertura de serviços de saúde. Cabe lembrar, também, que na relação mix público e privado, há oferta de leitos de hospitais públicos destinados aos planos de saúde privados.

\subsubsection{O mix público-privado}

O tema do "mix" público-privado vem encontrando crescente interesse dos organismos internacionais (PAHO, 1992), em contraste com o otimismo anterior em relação a um progressivo rumo em direção à estatização do financiamento e à prestação de serviços de saúde (TERRIS, 1980).

No Brasil, há uma literatura especializada em reformas dos sistemas de saúde nos anos 1990 extensa (LABRA, 1995; MENDES, 1996; GIOVANELLA e FLEURY, 1995; COSTA e RIBEIRO, 1996; UGÁ, 1997). Podem ser identificadas as seguintes transformações: inicialmente, uma profunda crise fiscal do setor público de saúde, concomitante a uma importante reforma das políticas e do aparelho do 
Estado e que se dá com a implantação do Sistema Único de Saúde/SUS (MENDES, 1996).

O gasto privado com saúde, ao contrário da década de 1980 quando foi menor que o gasto público (OPAS, 1990) tende a igualar-se com este, ambos em torno de 16 bilhões de reais, em 1996 (Gazeta Mercantil, 1996). Adversa, nacional e internacionalmente, foi a conjuntura política em que os preceitos constitucionais de universalização com eficácia deveriam ser concretizados.

A importância do SUS para o financiamento da rede hospitalar se torna decrescente em relação ao financiamento privado com os planos e seguros de saúde (VIANNA et al., 1987; BUSS, 1993). Paralelas às mudanças nas bases de financiamento, as modificações no comportamento dos hospitais e das empresas de seguro saúde apresentavam uma dinâmica do setor prestador de serviços de saúde, em que:

- cooperativas médicas e muitas empresas de seguro saúde compram hospitais, refletindo um movimento de verticalização cujos determinantes tanto podem estar na necessidade de contenção de custos hospitalares ou na manutenção de uma reserva estratégica de leitos;

- hospitais filantrópicos, tradicionais parceiros da previdência social e atualmente do SUS, com o estrangulamento de suas bases financeiras, buscam outras fontes de custeio, por meio das seguradoras e organizam planos de pré-pagamento próprios (CONFEDERAÇÃO DAS MISERICÓRDIAS DO BRASIL, 1992);

- hospitais privados contratados descredenciam leitos no SUS (MEDICE, 1992 apud OCKÉ, 1995) e aqueles que se mantêm no sistema são considerados como de baixa qualidade; 
- alguns municípios com modelos de gestão com maior autonomia de utilização de recursos federais complementam a tabela do SUS com alguns serviços do setor privado.

Um dos desafios que advém dessas transformações é o fortalecimento da regulação das práticas de saúde, apontada pelos organismos internacionais como uma das funções básicas do novo Estado reformado, que deve concentrar a sua intervenção, ao invés de financiamento e provisão (BANCO MUNDIAL, 1993). No entanto, apesar do esforço em explicitar os elementos que deviam norteá-la (ALMEIDA, 1998), estes não estão ainda suficientemente esclarecidos de modo a dotar o Estado e os atores envolvidos, de informações e guias para a ação.

Um dos problemas está nas limitações da teoria neoclássica, em especial no equilíbrio entre oferta e demanda e na racionalidade ilimitada dos agentes econômicos. Essa teoria está bastante consolidada nas literaturas internacional e nacional em Economia da Saúde, para o entendimento do funcionamento dos mercados em saúde.

Mesmo autores clássicos da regulação de mercados, no geral (KAHN, 1988), partindo de uma abordagem econômica tradicional, da análise das chamadas falhas de mercado ou imperfeições do processo competitivo (perfeito), questionam o funcionamento "natural" do mercado. Consideram-no, sim, historicamente imposto como ideal, com o desenvolvimento do capitalismo mercantil e industrial.

KAHN (1988) chama, ainda, a atenção aos limites do modelo neoclássico para tomar decisões, na medida em que seu funcionamento é restrito à existência de condições constantes, dificilmente vistas em conjunto nas situações concretas. Em geral, respaldado na teoria microeconômica convencional, o autor a considera incapaz de responder a outra ordem de problemas, como às perguntas como e por que arranjos institucionais e resultados ideais podem ser alcançados. 
O tema privatização é recorrente nas análises referentes à configuração das políticas de saúde no Brasil, principalmente após os anos 1960, mas centrados, principalmente, nas relações entre hospitais privados e Previdência Social. Muitas mudanças ocorreram desde então, porém o conceito continua sendo aplicado amplamente a processos distintos, o que não impediu esforços, na década de 1990, no sentido da melhor caracterização descritiva de segmentos do setor privado, como os hospitais privados (COTTA, et al., 1998) planos e seguros de saúde (ALMEIDA, 1998; BAHIA, 1999) e cooperativas médicas (ZUCCHI, 2002).

\subsection{EVOLUÇÃO E CONCEITOS DE LOGísticA E CADEIA DE SUPRIMENTOS (SUPPLY CHAIN)}

A logística existe desde os primórdios da humanidade; registros em passagens bíblicas e em achados arqueológicos demonstram a sua antiga existência. A questão estratégica da logística tem seus fundamentos na arte militar, pois dela nasceram os princípios logísticos. Assim, o conceito da logística que hoje é utilizado no mundo acadêmico e organizacional evoluiu e tomou forma a partir da vertente da arte militar e do desenvolvimento econômico.

$\mathrm{O}$ conceito de logística tornou-se conhecido com os estudos desenvolvidos na área militar, no século XVII, com o tratado do Barão de Jomini, intitulado Précis de l'Art de la Guerre (Compêndio da Arte da Guerra) de 1836. A serviço de Napoleão Bonaparte, Jomini se refere à logística como ação responsável pela preparação e sustentação das campanhas militares. Para Jomini, a logística significava a "arte prática de movimentar os exércitos", compreendendo as atividades como transporte, medidas administrativas, de reconhecimento e de informação necessárias para a movimentação e a manutenção de forças militares organizadas. 
Nas décadas de 1950 e 1960, a Logística Empresarial ganhou relevância, passando à consolidação pela busca da redução de custos no âmbito organizacional. A competitividade é marcada pela constante evolução, cujas forças mutativas voltavam seu foco ao cliente, como direcionador da eficiência e produtividade, realçada pela crise no petróleo, escassez de matérias-primas e aumento da inflação mundial. Em face ao periodo de reestruturação empresarial surgiu, como resposta à instabilidade oriunda da crise dos anos 1980, a Logística Integrada.

A logística passou a ser identificada como elemento diferenciador e propulsionador da competitividade advinda da preocupação com as interfaces entre as diversas funções organizacionais (COYLE, BARDI \& LANGLEY, 1996). Proveniente desse ambiente de mudanças surgiu, no início da década de 1980, o Supply Chain, filosofia que perdura até os dias atuais, integrada por um rol de organizações cujo objetivo macro é a satisfação do cliente final (BOWERSOX, 2001; BALLOU, 2001; CHRISTOPHER, 1997).

A evolução perdura com o passar do tempo, moldando os futuros ambientes organizacionais e produtivos. $\mathrm{O}$ que inicialmente constituía a Administração de Materiais, por meio do gerenciamento de estoques, compras e movimentação de materiais foi evoluindo, e atualmente fala-se na visão sistêmica da organização e dos sistemas aos quais ela se reporta.

A logística empresarial é composta de atividades primárias (transporte, manutenção de estoques e processamento de pedidos), que possuem fundamental importância na redução dos custos e maximização do nível de serviços. As demais atividades: armazenagem, manuseio de materiais, embalagem, suprimentos, planejamento e sistemas de informação - são consideradas atividades de apoio, pois dão suporte às atividades primárias com o intuito de satisfazer e manter clientes, além de maximizar a riqueza dos proprietários. A logística passou a ser identificada 
como um elemento diferenciador entre as empresas, por meio da qual é possível explorar novas e importantes vantagens competitivas.

A logística vista no passado como processo de abastecimento de materiais ou mesmo como atividade de transporte na distribuição física, ganhou maior abrangência nos anos 1980, quando as organizações perceberam sua importância na administração integrada dos processos de suprimentos, produção e distribuição física, ficando estabelecido o conceito da logística integrada.

Dos conceitos e definições de Logística, FERREIRA (1986) traz: do grego logistike, relativo ao cálculo, denominação dada pelos gregos à parte da aritmética e da álgebra concernente às quatro operações; da filosofia, conjunto de sistemas de algoritmos aplicados à lógica; e do francês, logistique, parte da arte da guerra que trata do planejamento da realização de projeto e desenvolvimento, obtenção, armazenamento, transporte, distribuição, reparação, manutenção e evacuação de material; recrutamento, incorporação, instrução, designação, transporte, bem-estar, evacuação, hospitalização e desligamento de pessoal. Além disso, aquisição ou construção, reparação, manutenção e operação de instalações e acessórios destinados a ajudar o desempenho de qualquer função, e também, contrato ou prestação de serviços.

$\mathrm{Na}$ evolução, o pensamento logístico era voltado até então, para a identificação dos principais aspectos da eficiência no fluxo de materiais, em especial às questões de armazenamento e transporte, tratadas separadamente no contexto da distribuição de bens. A logística, a partir da década de 1970, começou a ser utilizada pelas empresas e foi definida como um modelo de análise e administração integradas, explorando aspectos como custo total e abordagem de sistemas.

Apenas recentemente as organizações têm experimentado a logística integrada, ou seja, os serviços logísticos ligando toda a cadeia. Com o passar do 
tempo, transformou-se em uma estratégia que coloca sob o mesmo "guarda-chuva" diversas funções de uma organização ou diversas organizações de uma cadeia de distribuição ou de serviços.

BOWERSOX (1980, p.3) apresenta a logística como "um sistema lógico para guiar o processo de planejamento, alocação e controle dos recursos financeiros e humanos comprometidos com a distribuição física dando suporte a operações de produção e compras". O autor comenta que o conceito básico de gerenciamento logístico é aplicado tanto nas empresas privadas quanto na pública, no estudo relacionado aos hospitais públicos e privados.

De acordo com PIRES (2004), o gerenciamento da cadeia de suprimentos é um conceito extremamente avançado no campo da administração de materiais, sobretudo abrangente e estratégico, pois possibilita a gestão integrada de toda a cadeia produtiva. Entretanto alguns fatores inibem o desenvolvimento do mercado de Gerenciamento da Cadeia de Suprimento no Brasil; destacam-se, entre eles, a pouca confiança nos fornecedores nesse tipo de solução, altos custos de implementação e a falta de um claro entendimento em relação aos beneficios das ferramentas.

Por outro lado, POIRIER e REITER (1997, p.19) citam que a forma mais moderna e eficaz para uma organização conduzir seus produtos e serviços é pela cadeia de suprimentos, que é definida pelos autores como “(...) um sistema pelo qual as organizações entregam seus produtos e serviços a seus clientes”. Esse sistema se apresenta em forma de redes interligadas, cada uma com seus significados e componentes, com o objetivo de melhorar o processo pelo qual as organizações realizam suas entregas e serviços.

De acordo com a definição do Council of Logistics Management (CLM), logística é o processo de planejamento, implementação e controle do fluxo eficiente e economicamente eficaz de matérias-primas, materiais em processo, produtos 
acabados e informações relacionadas com essas atividades, desde o ponto de origem até o ponto de consumo, com o objetivo de atender às exigências dos clientes. Para BOWERSOX (2001), a logística é o processo de planejamento que implementa e controla a eficiência e a eficácia do fluxo de produtos, serviços e informações relacionadas, do ponto de origem para o ponto de concepção, em conformidade com a necessidade do cliente.

Muitas organizações estão optando pela logística como estratégia para melhorar seus resultados financeiros e aumentar seu poder de diferenciação. CHRISTOPHER $(1997$, p. 2) formula a seguinte definição:

A logística é o processo de gerenciar estrategicamente a
aquisição, movimentação e armazenagem de materiais,
peças e produtos acabados (e os fluxos de informações
correlatas) através da organização e seus canais de
marketing, de modo a poder maximizar as lucratividades
presente e futura através do atendimento de pedidos a
baixo custo.

Para BALLOU (1993), a missão da logística é disponibilizar o produto certo, na quantidade certa, no local certo, no momento certo, nas condições adequadas, para o cliente certo ao preço justo. Esse autor incorpora na missão da logística sua contribuição aos resultados da organização, caracterizando o papel estratégico que deve desempenhar.

Ao analisar o conceito e a missão nota-se que a logística, em sua essência, está focada em simultaneamente em reduzir custos e maximizar valor. O resultado esperado é a satisfação do cliente e a rentabilidade ou sustentabilidade da organização. 
Das considerações feitas até o momento, fica evidente que a logística é um processo de gestão do fluxo de bens e serviços, centrado em sua dinâmica, e, em função disso, difícil de ser mensurado.

A evolução da logística tem se apresentado nas organizações com o alargamento do seu escopo e a integração de suas atividades, passando a abarcar funções anteriormente conduzidas de forma fragmentada. Do fluxo material, centrado nas atividades de transporte e armazenagem, a logística passa, também, a gerenciar e ter como componentes fundamentais os fluxos de informação e financeiro, estendendo seu âmbito de atuação para a integração.

Para CHRISTOPHER (1997), a função logística, ao encontro de valor proposta por Porter, agrega valor ao cliente. Neste estudo defende-se que a logística, nos serviços de saúde, pode agregar valor ao paciente, por reduzir tempos e agregar confiabilidade à entrega do serviço, contribuindo na diminuição de custos financeiros e de capital referentes a estoque (figura 1).

Segundo WOOD e ZUFFO (1998), as organizações ao optarem pela utilização da logística foram modificando sua definição e ampliando o seu escopo, e, dessa forma, contribuíram para a evolução do seu conceito. Ao mesmo tempo, aumentava suas contribuições para a performance da organização e a logística deixava de ser vista de maneira puramente técnica, relegada ao nível operacional, e ganhava um tratamento estratégico.

Outra visão interessante é a da expansão de suas fronteiras. Segundo CHRISTOPHER (1997), num primeiro momento cada uma das funções da empresa realizava suas atividades de forma independente e desconexa; depois houve o reconhecimento da necessidade da integração dessas funções, e, por último, foram rompidas as fronteiras da empresa e integrado todos os elos da cadeia de suprimentos. Dessa forma, a evolução aconteceu de dentro para fora e evoluiu para a criação de uma cadeia entre fornecedores e clientes. 
Figura 1 - A logística e o valor para o paciente

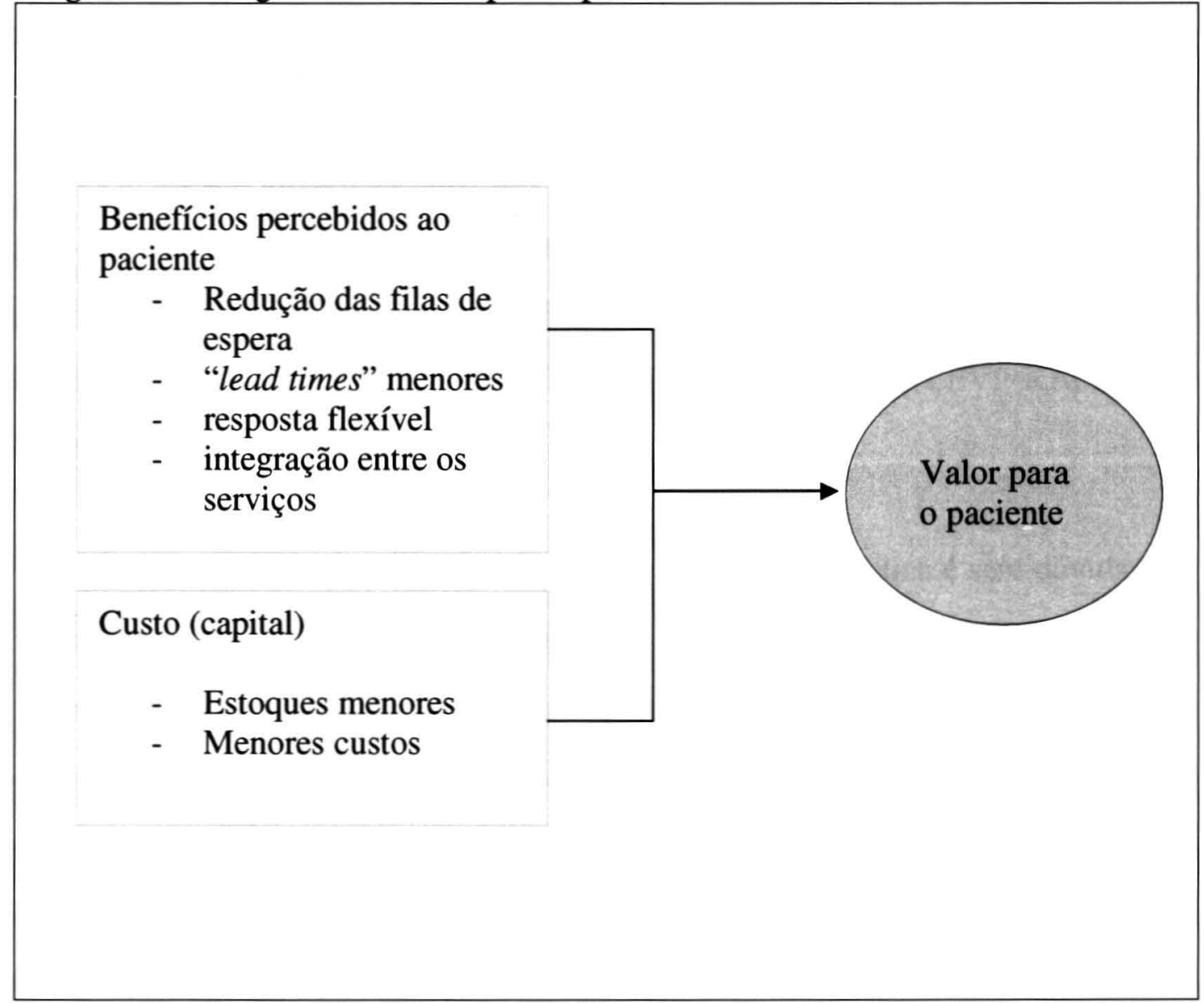

Fonte: Adaptado de Christopher, 1997.

Sob o antigo paradigma a logística foi entendida como uma série de funções contínuas como transporte, suprimentos, estocagem, entre outras. Contudo, sob o novo paradigma se deve pensá-la como uma cadeia de eventos que são totalmente vinculados, interdependentes e centralizados no cliente (MOURA et al, 2003).

A cadeia de suprimentos abrange as atividades internas e externas. Cadeias internas são as funções, processos e atividades dentro de uma unidade de negócio ou organização, embora as cadeias externas se refiram ao vínculo de funções específicas entre parceiros para benefício mútuo: portanto, a logística da cadeia de 
suprimento, planejamento e execução do pensamento de ponta a ponta (MOURA et al, 2003).

Com a integração interna e externa e o uso da tecnologia da informação, torna-se possível a sincronização do fluxo de materiais com o fluxo de informações. Assim, se ganha eficiência e flexibilidade e se oferece um melhor nível de serviço aos clientes (BALLOU, 2001; CHRISTOPHER, 1997 e SIMCHI-LEVI; KAMINSKI e SIMCHI-LEVI, 2003).

A vertente mais rica no atual pensamento em logística é sem dúvida a de Gerenciamento da Cadeia de Suprimento. Ela conjuga os processos logísticos, que tratam do fluxo de materiais e informações dentro e fora das organizações, com os relacionamentos que surgem ao longo da cadeia para assegurar seus melhores resultados em termos de redução de desperdício e agregação de valor. Ao lidar com os relacionamentos entre organizações é natural que o pensamento logístico aborde, também, a questão das parcerias e alianças estratégicas logísticas. Essas estratégias colaborativas promovem a união de forças de empresas - cliente e fornecedora, cliente e cliente ou fornecedora e fornecedora - visando explorar as atividades logísticas em busca de vantagens mútuas (FLEURY e ARKADER, 2000).

Dessa forma, remete-se à evolução do pensamento logístico. A cada momento, a prática da logística reflete e ao mesmo tempo alimenta o pensamento logístico, em uma criativa interação entre o meio acadêmico e o meio organizacional. Os autores afirmam que o campo da Logística evoluiu de um tratamento mais restrito, voltado para a distribuição fisica de materiais e bens, para um escopo mais abrangente, em que se considera a cadeia de suprimentos como um todo e as atividades de compras, administração de materiais e distribuição. Assim, não se limita a uma única função dentre as estudadas em Administração, mas representa, de 
fato, uma área de integração de distintos enfoques. (FIGUEIREDO, ARKADER, 2000).

Figura 2 - O novo paradigma da logística

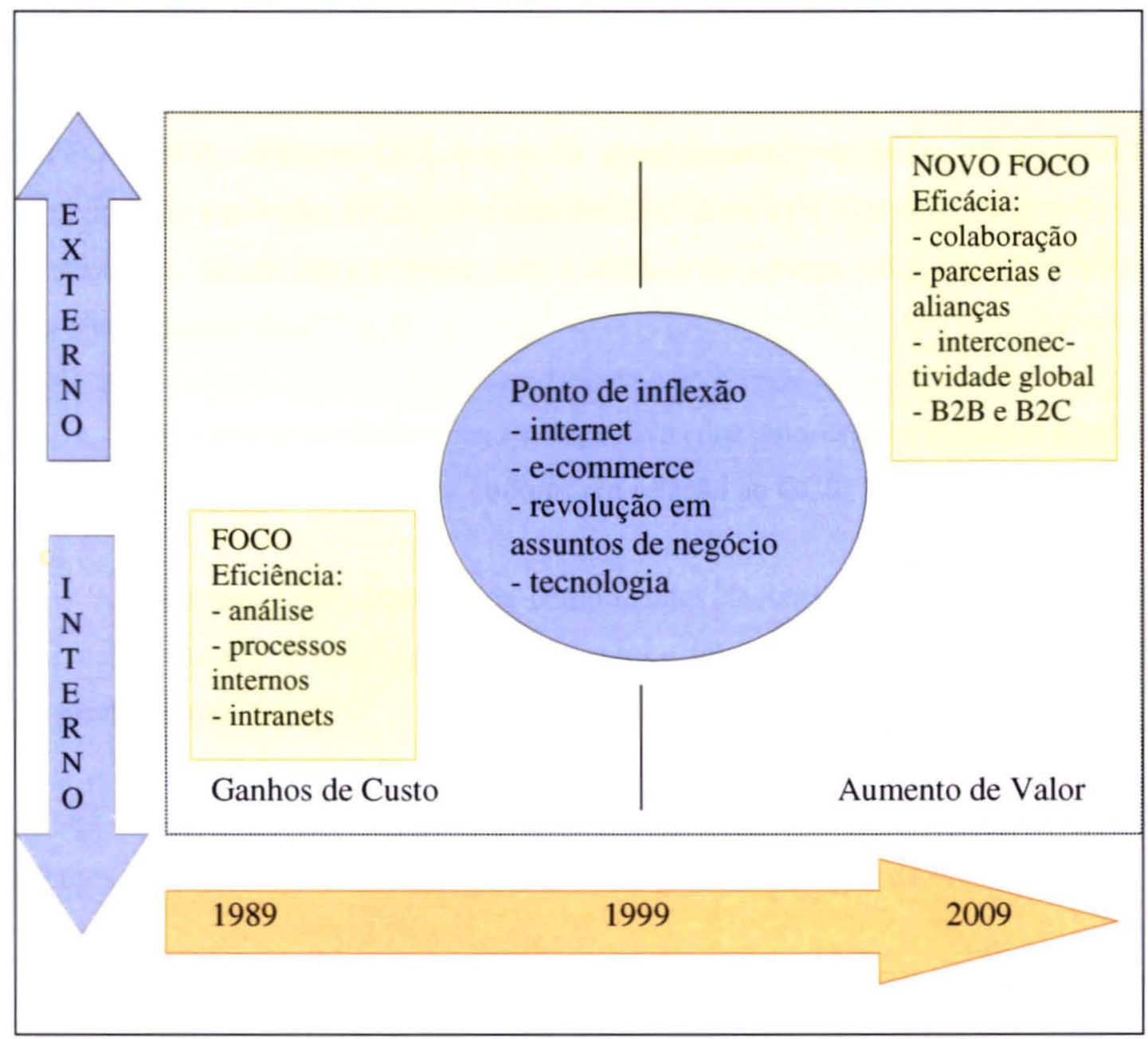

Fonte: Adaptado de Moura et al., 2003.

O desafio da gestão hospitalar, em um cenário econômico de recursos escassos sugere a necessidade de uma revolução na maneira de gerir um hospital. Para enfrentar situações adversas, como gastos crescentes com os procedimentos hospitalares, renda insuficiente dos usuários dos serviços hospitalares, discussões freqüentes entre as operadoras de planos e seguros de saúde, o governo e os usuários, 
o foco da tomada de decisão deverá ser não apenas os custos, mas também, e principalmente, o resultado que propicie ganho de valor.

Muitas são as abordagens referentes ao Gerenciamento da Cadeia de Suprimentos ou Supply Chain Management, (BALLOU, 2001, BOWERSOX e CLOSS; 2001; CHOPRA e MEINDL, 2004; CHRISTOPHER, 1997; SIMCHILEVI; KAMINSKI e SIMCHI-LEVI, 2003 e SLACK et al., 1996). WOOD e ZUFFO (1998), definem GCS como "o gerenciamento de todas as atividades envolvidas na aquisição, produção e distribuição, através da completa integração de fornecedores, fabricantes e clientes, com o objetivo de agregar valor e reduzir custos para o consumidor final".

Nas diferentes definições e perspectivas dos autores anteriormente citados podem ser estabelecidos os pontos comuns em relação ao GCS:

- é necessário integrar os componentes de uma cadeia de suprimentos para melhor atender às necessidades dos clientes e aumentar o poder de diferenciação dos produtos e serviços;

- para que se consiga melhorar a rentabilidade dos membros da cadeia os esforços para reduzir custos e agregar valor extrapolam os limites da organização;

- a logística passa a ser um assunto estratégico, e a competência na coordenação dos serviços logísticos passa a ser fundamental para a competitividade;

- a adoção do GCS permite obter um desempenho superior, tanto operacional como financeiro, e aumentar a competitividade da cadeia.

Ao se tratar dos temas Logística e Cadeia de Suprimentos, torna-se necessário esclarecer que existe uma grande discussão, nos campos acadêmico e organizacional, relacionada à questão de se definir a GCS: se é uma versão ampliada e atualizada da logística ou se são coisas diferentes. 
LAMBERT, COOPER e PAGH (1998, p. 21) definem GSC como

“a integração dos processos de negócio de uma cadeia produtiva, desde o ponto de origem até o ponto de consumo, visando fornecer produtos, serviços e informações com valor agregado aos clientes e outros stakeholders".

De acordo com essa definição, o GCS deveria abranger os processos de desenvolvimento de produtos, aquisição, manufatura, gestão da demanda, relacionamento com cliente, atendimento do pedido e distribuição. O GCS pode ser considerado uma tentativa de estabelecer um corte transversal das fronteiras organizacionais visando viabilizar a gestão de processos entre corporações. Porém, advertem os próprios autores que gerenciar uma cadeia de suprimento é uma tarefa desafiadora e salientam que é muito mais fácil escrever definições referentes a esses processos do que implementá-los.

Como todo conceito novo, não há ainda um corpo de pensamento consolidado na área de Gerenciamento da Cadeia de Suprimento.

\subsection{LOGÍSTICA E SERVIÇOS DE SAÚDE}

A transição e passagem para o século XXI não foi imune às mudanças de vários graus de intensidade, em todos os tipos de ambientes - competitivo, tecnológico, econômico, social - provocaram o surgimento de novos conceitos e técnicas para administrar as organizações incluindo as de saúde, sendo muitas delas idéias antigas, que vinham evoluindo ao longo do tempo (MAXIMIANO, 2004).

No contexto das políticas de saúde, a descentralização na agenda de reformas dos anos 1990 incluiu questões de reorganização de sistemas, privatização e flexibilização. Na área da saúde, o SUS constitui um modelo de organização dos 
serviços de saúde que tem como uma das suas características primordiais valorizar o nível municipal. Assim, tem como proposta de organização a implantação dos sistemas de saúde municipal articulados regionalmente; em outras palavras, sistemas regionalizados com base municipal, num processo de negociação permanente e dinâmica entre os níveis de governo municipal, estadual e federal, para assegurar melhor atenção à saúde da população (ALMEIDA; CASTRO; VIEIRA, 2001). A descentralização e a regionalização também têm sido consideradas fatores orientadores na construção das políticas de assistência hospitalar (MINISTÉRIO DA SAÚDE, 2004).

Sob influência dos desenvolvimentos conceituais da administração de organizações contribuídos por Fayol e Taylor, os sistemas de saúde se organizaram em níveis hierárquicos com responsabilidades e competências definidas, pautados em uma organização piramidal de serviços e em estruturas administrativas burocráticas.

Diante dos novos paradigmas, como por exemplo, a produção enxuta (WOMACK e JONES, 1998) os gestores de saúde vem se posicionam contrários à organização piramidal e aceitam uma concepção alternativa de redes de serviços, local e inter-relacionada, segundo FLEURY (2002) numa visão gerencial de redes interorganizacionais e intergovernamentais. Tais redes vinculam-se a processos políticos que, muitas vezes, distanciam-se de seus objetivos quando operacionalizadas.

Outra questão a ser considerada é que dada a diversidade de estruturas que variam segundo interesses de diferentes atores, natureza do objeto-situação e o tipo de interdependência, vertical com seus membros e horizontal com demais redes, as redes no setor público são fortemente influenciadas pela distribuição de recursos, o qual determina funções e competências entre os níveis de governo, referidos a estratégias.

Embora compreenda-se que a estratégia de logística no setor de serviços abrange a amplitude de rede logística, neste estudo, focou-se a cadeia de suprimentos 
em serviços de saúde, especificamente em cinco hospitais, públicos e privados, localizados no município de São Paulo. Porém, ao pautar-se sobre organizações hospitalares, remete-se a posição que estas ocupam no sistema de saúde e os desafios que enfrentam face à reformulação e nova posição no sistema de saúde. Ao formar parte de uma rede de serviços de saúde, o hospital amplia seu horizonte de atuação e enfrenta relações mais diversas (OPAS, 2004).

Ao tratar de suprimentos, é perceptível para a sociedade, e especialmente para os usuários ou clientes dos serviços de saúde, que os estabelecimentos de saúde, dentre eles os hospitais públicos e privados, precisam sempre estar preparados para atender demandas extremas. A área de administração de recursos materiais deve estar preparada para responder às necessidades de todos os pacientes, incluindo os que ingressam pela porta de emergência. Essas demandas, incontroláveis e imprevisíveis, colocam a indústria médico-hospitalar no rol das atividades mais complexas: preservar a saúde e a vida dos pacientes. O adequado gerenciamento de estoques é imprescindível para o sucesso dos objetivos dos serviços de saúde.

Segundo a OPAS (2001), a abordagem logística recebe um tratamento de grande importância na gestão hospitalar, pois atividades complexas como armazenamento, movimentação e abastecimento de medicamentos e de outros produtos auxiliares estão contidos no cotidiano dos hospitais.

Observa-se que as atividades citadas são abordagens tradicionais da logística, ou seja, a logística no ambiente hospitalar limitada ao ramo da armazenagem. Neste estudo, o conceito de logística, além de almoxarifados, controle de estoque e armazéns, contempla-o enquanto estratégia e inserção da organização hospitalar na cadeia de suprimentos de saúde.

$\mathrm{O}$ enfoque sistêmico pode ser ampliado à logística integrada que requer uma visão ampla e integradora como sua função maior. A logística, para que possa ser gerenciada de forma integrada, deve ser tratada como um sistema, ou seja, um 
conjunto de componentes interligados, trabalhados de forma coordenada para atender a um objetivo comum (FLEURY, WANKE \& FIGUEIREDO, 2000).

Existem três subsistemas básicos que são os eixos de todo gerenciamento: o de suprimentos, o de produção e o de distribuição. Nesse conjunto de subsistemas, o gerenciamento logístico cuida não somente do fluxo físico de materiais, estoques em processo, mas sugere o gerenciamento integrado de outros dois fluxos essenciais para o bom desempenho da logística, que são o de informação e o financeiro. Nesse sentido, o gerenciamento deve ser tanto no sentido horizontal quanto vertical.

$\mathrm{Na}$ figura 3 estão representados, esquematicamente, os principais componentes da logística atual, embasados na literatura revisada, serão utilizados na análise do sistema logístico das organizações hospitalares, objeto deste estudo.

Figura 3 - Sistema logístico de suprimento na Organização Hospitalar

Fluxo do valor agregado

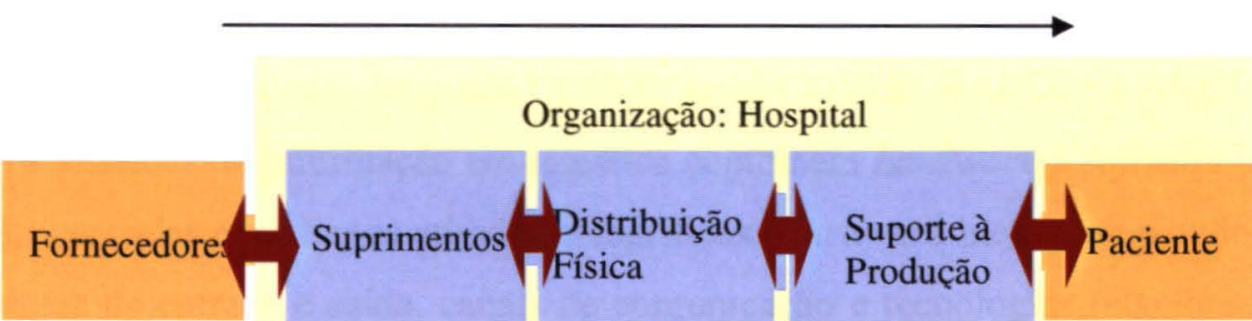

Fluxo de materiais

Fluxo de informação

Fluxo Financeiro

Fluxo Reverso 
$\mathrm{Na}$ área da saúde há de se considerar a interface dos profissionais de saúde, uma vez que a escolha do cliente/paciente, na maioria das vezes, passa pela receita ou indicação do profissional que o atendeu. No caso específico de hospitais, os profissionais de saúde interagem, muitas vezes, nos itens demandados na cadeia de suprimentos.

O gerenciamento desses fluxos, objeto de atenção da logística, deve ser realizado de forma a coordenar e integrar todas as atividades envolvidas, o que contribuirá para que a organização consiga os benefícios de otimização de recursos, redução de estoques e diminuição de custos, melhorando, assim, sua competitividade e sustentabilidade (BOWERSOX e CLOSS, 2001).

O fluxo financeiro representa os pagamentos realizados pelos clientes/pacientes representados pela operadora de saúde ou Governo, ou por meio dos atendimentos particulares pagos diretamente ao hospital e deste para os fornecedores e prestadores de serviços terceirizados.

As atividades de logística são cada vez mais realizadas com a utilização de sistemas computadorizados para acompanhamento e controle dos materiais e das informações a eles relativas. Segundo CLOSS, apud COYLE, BARDI e LANGLEY (1996), os sistemas de informação em logística combinam hardware e software para gerenciar, controlar e mediar as atividades logísticas. Hardware inclui computadores, instrumentos de entrada e saída, canais de comunicação e tecnologias relacionadas, tais como código de barras, instrumentos de rádio-frequência e equipamentos de estocagem. Software inclui sistemas e programas de aplicação usados para atividades logísticas.

Equipamentos auxiliares e software para melhoramento do processo logístico vêm sendo desenvolvidos e incorporados nas organizações, o que envolve a necessidade de permanente atualização tecnológica para a adequada execução dos serviços e fluxos logísticos e no caso dos hospitais, investimentos e capacitações para o adequado funcionamento desses fluxos. 
Neste estudo agregam-se também os fluxos reversos, que cuidam de materiais que se iniciam nos pontos de consumo e terminam no ponto de origem, com o objetivo de recapturar valor ou disposição final (LEITE, 2003). Nos serviços de saúde, em análise, são representados pelas iniciativas ou sistematização dos canais reversos demonstrados pelo fluxo reverso dos materiais reprocessados, resíduos quanto à reutilização, reciclagem ou outra destinação e também pelo retorno dos materiais não utilizados nas clínicas ou setores dos hospitais estudados.

No fluxo reverso, um dos principais objetivos é recuperar o maior valor possível dos produtos, segundo FLEISHMAN et al. (2000), e para atingir esse objetivo devem ser realizadas, sequencialmente, as etapas: recolhimento, inspeção/separação, reprocessamento, disposição e/ou redistribuição. A otimização dos fluxos reversos na cadeia de suprimentos pode contribuir para a redução dos custos globais de toda a cadeia e apresentar o impacto ambiental positivo.

A logística é um componente fundamental na produção enxuta, pois o fluxo na produção e a saída e entrada de materiais demandam planejamento adequado e execução precisa, sem erros. Dessa forma, em vez de estabelecer relações com muitos fornecedores, os relacionamentos são concentrados em um pequeno número fornecedores e distribuidores diretos, cada qual responsável por sua logística e por obedecer aos requisitos contratualmente acordados.

A produção enxuta impulsionou um completo repensar no modo de produzir produtos e serviços. Para implementar e aplicar suas técnicas é necessário um novo gerenciamento do negócio. A organização deve adotar uma visão expandida, englobando fornecedores e distribuidores para construir um ótimo sistêmico e criar sinergias das competências dos membros da cadeia (TUBINO, 1999). 


\subsection{MENTALIDADE ENXUTA E O COMPONENTE LOGÍSTICA ENXUTA}

Os princípios da mentalidade enxuta se refletem, de forma evidente, na busca da logística enxuta, que tem por objetivo prover os clientes, no caso deste projeto os pacientes, com serviços no menor tempo possível para, assim, a organização ser mais efetiva, tanto na facilidade do acesso e fluxo do paciente quanto na movimentação racional dos materiais necessários.

A mentalidade enxuta e seu componente, logística enxuta, indicam a nova visão dos serviços de logística integrada, que se confunde com a de administração da cadeia de suprimentos e faz parte da reestruturação das operações, com base no fluxo de valor puxado pela demanda dos clientes, que é mais coerente ao favorecer a mudança da lógica da demanda pautada nas necessidades do paciente e não na oferta produzida; na introdução da operação flexível da produção, na busca de custos logísticos totais menores e serviços mais adequados às necessidades dos clientes, em termos de prazos, valores e serviços associados.

WOMACK e JONES (1998, p. 3) definem resumidamente mentalidade enxuta como:

forma de especificar valor, alinhar na melhor seqüencia as ações que criam valor, realizar essas atividades sem interrupção toda vez que alguém solicita e realizá-las de forma cada vez mais eficaz. Em suma, a mentalidade é enxuta, porque representa uma forma de fazer cada vez mais com menos - menos esforço humano, menos equipamento, menos tempo e menos espaço e, ao mesmo tempo, aproximar-se cada vez mais de oferecer aos clientes exatamente o que eles desejam. 
Percebe-se que os autores defendem a transformação do processo produtivo para a produção puxada (pull), ao invés da produção empurrada (push). A mentalidade enxuta pode ser apresentada, também, como resultante da aplicação de cinco princípios: (a) determinação do valor; (b) identificação da cadeia de valor; (c) fazer o valor fluir sem interrupções; (d) permitir que o cliente puxe o valor; (e) buscar a perfeição.

Na produção enxuta, a produtividade é consequência de um processo planejado e integrado, em que todas as partes conhecem o processo e minimizam os erros, o que força a produção a se adequar à demanda do mercado e às customizações exigidas pelos clientes (CORRÊA e CORRÊA, 2004). No provimento dos materiais são utilizados os conceitos de just-in-time, que segundo OHNO (1997, p. 25):

Just-in-time significa que, em um processo de fluxo, as partes corretas necessárias à montagem alcançam a linha de montagem no momento em que são necessárias e somente na quantidade necessária. Uma empresa que estabeleça esse fluxo integralmente pode chegar ao estoque zero.

A Mentalidade Enxuta apresenta-se como uma filosofia de gestão, buscando melhorar a eficiência com a redução de desperdícios. A noção de desperdício está fortemente ligada ao conceito de valor na visão do cliente, ou seja, identifica as atividades que são percebidas como valor na ótica de quem realmente paga pelos produtos (WOMACK et al., 1996).

No mundo empresarial, as organizações estão se adaptando ao modelo de Produção Enxuta, que requer a excelência em logística como forma de gestão da cadeia produtiva para conseguir a coordenação e o alinhamento estratégico dos componentes da cadeia (TUBINO, 1999). O foco é o cliente e a inovação é constante; nesse contexto, as vantagens e diferenciais competitivos são cada vez mais efêmeros. 


\subsection{DESEMPENHO LOGÍSTICO}

Os gastos com logística são relevantes em todo o mundo, representando de 5 a $35 \%$ do valor das vendas, dependendo do tipo de atividade, da operação e da relação peso/valor dos produtos e materiais (BOWERSOX e CLOSS, 2001).

$\mathrm{Na}$ área da saúde, materiais e medicamentos representam parte substancial dos gastos e evidenciam a tecnologia utilizada. Dados referentes à participação de materiais e medicamentos em hospitais do Reino Unido indicam corresponder entre 13 a $17 \%$ dos custos hospitalares (HFMO, 2005). No Brasil, segundo VECINA e REINHARDT (2002), os gastos com materiais representam aproximadamente de 15 a $25 \%$ do total das despesas correntes.

De acordo com ANGARAN (1999), nos Estados Unidos o custo dos medicamentos destinados aos pacientes hospitalizados apresentou um crescimento significativo, mais expressivo do que a inflação dimensionada para a saúde no mesmo período: o custo das drogas/leito ocupado/ano cresceu de US\$6,744 em 1989 para US\$21,677 em 1998, o que representa $221 \%$ de aumento, ou $25 \%$ de aumento/ano em um período de nove anos. Observa-se que os custos operacionais da saúde são crescentes, tanto às organizações de saúde de caráter privado quanto aos cofres públicos, implicando a utilização de mecanismos gerenciais como planejar e controlar custos.

Diferentes técnicas de gestão de estoques e de administração da produção foram desenvolvidas, a fim de solucionar os problemas originados no ambiente da manufatura, com eficiência na gerência de operações de uma indústria. Essas técnicas podem ser adaptadas às novas necessidades presentes na gestão de serviços, têm aplicação nas farmácias das instituições hospitalares e buscam a otimização do controle dos estoques (GONÇALVES, 2004), levando-se em consideração suas peculiaridades. 
Além de apoiar a mensuração do desempenho logístico, um alto grau de tecnologia de informação e de formalização e o uso de sistemas de monitoramento de desempenho eficazes resultam em flexibilidade logística (BOWERSOX, 1989). Os sistemas de informação também podem ser um empecilho na implementação de sistemas de mensuração de performance. A razão é que algumas empresas possuem uma mistura de computadores, softwares e estruturas de database novos e antigos, o que em geral exige um grande esforço na implementação de mudanças (HOLMBERG, 2000).

No ambiente competitivo brasileiro, a mensuração das atividades logísticas adquiriu importância com o fim da escalada inflacionária que alterou o foco dos empresários fazendo com que deixassem de pautar-se na busca por ganhos financeiros e passassem a valorizar o real valor de produtos e serviços (FLEURY e LAVALLE, 2000). Além disso, o alto custo do capital no país tornou a manutenção dos níveis dos estoques baixos um fator fundamental para a manutenção da competitividade de indústrias e varejistas (FIGUEIREDO et al, 2003).

Para DORNIER (2000) apud KATO (2003), a integração e a globalização da logística impactam na definição e utilização de medidas de desempenho logístico que devem adaptar-se à atual realidade, a fim de proporcionar o controle eficaz de custos e operações. Os autores supramencionados afirmam, ainda, que os indicadores logísticos são as ferramentas-chave do sistema de controle, orientados pela política estratégica organizacional.

Para medir o desempenho da função logística é necessário ter como marco de referência os indicadores genéricos e holísticos utilizados pela organização (REY, 1999). Portanto, RODRIGUEZ (2005) destaca que na medição do desempenho logístico não se deve procedê-la sem previamente: a) identificar a estratégia da organização e sua estratégia logística; b) determinar os objetivos do sistema logístico; e c) estabelecer os componentes do sistema logístico. 
Elencam-se, segundo BOWESOX \& CLOSS (2001), os três objetivos principais do desenvolvimento e implementação de sistemas de medição de desempenho logístico: a) monitorar os indicadores, que incluem o nível de serviço e os componentes dos custos logísticos; b) controlar continuamente o desempenho, a fim de aprimorar o processo logístico e colocá-lo em conformidade; e c) direcionar as operações logísticas, para motivar o pessoal e aumentar a produtividade.

Um sistema de avaliação de desempenho deve considerar que as medidas podem ser efetuadas em atividades e processos, internos ou externos. Dessa forma, tais medidas podem ser classificadas nas categorias custo; serviço ao cliente ou tempo de resposta; produtividade; e qualidade.

\subsection{JUSTIFICATIVA}

A democratização do sistema de saúde brasileiro, em grande parte apoiada na contratação de serviços privados, favorece o crescimento do mercado de serviços médico-hospitalares. Simultaneamente ao crescimento, observa-se que mudanças político-institucionais na regulação e no financiamento, o ingresso de operadoras internacionais e o ambiente marcado pelas incertezas impõem imperativos quanto ao aumento da eficiência e qualidade e a redução de custos operacionais. Ressalta-se, ainda, que independente da sua categoria de atuação no mercado - pública ou privada, lucrativa ou não lucrativa - as organizações estão submetidas às constantes mudanças referentes ao financiamento de seu processo produtivo, e às alterações de mercado de consumo de serviços médico-hospitalares, exigindo, dessa forma, respostas estratégicas capazes de contribuir para o desenvolvimento do setor (FERREIRA, 2000).

Como resultado do próprio processo de democratização, as pessoas estão mais conscientes e exigentes com relação à perspectiva dos direitos humanos gerais e 
sanitários. Elas querem segurança no acesso ao serviço de saúde de boa qualidade. Tais expectativas podem afetar a confiança depositada em seus governantes, no caso dos hospitais públicos e dos financiados pelo setor público, e, segundo a OPAS (2004), em última instância repercute na própria governabilidade democrática.

Outro aspecto importante refere-se aos gastos crescentes na área da saúde, que preocupam o governo, as empresas, os planos de saúde e seus beneficiários, além das causas comumente levantadas para explicar o aumento sucessivo dos custos, como o envelhecimento da população, os avanços tecnológicos que impulsionam o surgimento de novos medicamentos, materiais e equipamentos.

KUMAR e OZDAMAR (2001) levantaram a hipótese de que uma das causas se deve à ineficiência na cadeia de suprimentos da saúde, que poderia ser significativamente corrigida se as melhorias práticas de gestão de cadeia de suprimentos fossem adotadas. Contrariamente ao aumento dos gastos em saúde, o sistema brasileiro é marcado, por outro lado, pela expansão da quantidade e diversidade de serviços prestados tanto em estabelecimentos públicos quanto em privados financiados pelo SUS. (CARVALHO, 2008).

Os hospitais são organizações complexas e resguardam diferenças em relação à indústria manufatureira, de onde provém a maior parte da literatura referente à logística e gestão da cadeia de suprimentos. A análise do sistema logístico nos hospitais, considerando os aspectos mais estratégicos, e com o intuito de levantar os temas que influenciam a gestão de compras, de estoque, de distribuição e integração nos hospitais, é de grande importância para o melhor entendimento do sistema de saúde.

A gestão da cadeia de suprimentos é um campo de conhecimento recente, em que as teorias estão sendo construídas, e tem sido uma tendência nessa área, segundo LAMBERT (2001), de a academia seguir, ao invés de conduzir, as práticas organizacionais. Dessa forma, tem-se a expectativa de que estudar logística e cadeia 
de suprimento enquanto estratégia nas organizações de saúde, pode contribuir com a academia na construção de conhecimento acerca desse tema.

Nesse sentido, emergem alguns questionamentos: como a logística, enquanto estratégia, vem sendo implementada nos serviços de saúde, especificamente dos hospitais públicos e privados? Será que o sistema logístico implementado nos hospitais, públicos e privados, favorece o acolhimento de forma humanizada? Em quanto poderia melhorar a gestão hospitalar (redução de custos, tempo, satisfação do cliente/paciente/usuário e do cliente interno) com a implementação de novas ações logísticas? É possível conhecer como se comportam os fluxos logísticos nas organizações de saúde? Os hospitais enxergam a cadeia de organizações de saúde como um todo ao elaborar suas estratégias?

Esta tese desenvolver-se-á na área de conhecimento de logística no setor de serviços, no caso específico dos serviços de saúde, com enfoque na gestão estratégica, e, nessa área, terá por escopo a eficácia organizacional direcionada ao sistema logístico das organizações a serem pesquisadas.

Considerando o exposto, a proposta que se coloca para discussão neste trabalho é: será que as organizações hospitalares públicas e privadas estão inovando sua gestão na área de suprimentos e utilizando o Supply chain no sistema logístico de suprimentos, para garantir a sustentabilidade e agregação de valor aos pacientes?

$\mathrm{Na}$ caracterização do sistema logístico em saúde foram identificadas algumas tendências que apontam para a necessidade de os hospitais: assegurarem a logística como ferramenta estratégica, cumprirem a função logística de agregação de valor ao cliente; e reconhecerem a necessidade de integração das diferentes funções da organização hospitalar. É preciso, também, que os processos logísticos estejam conjugados com os relacionamentos ao longo da cadeia, reduzindo desperdício e agregando valor; incluindo a interface dos profissionais de saúde. 


\section{OBJETIVOS}

$2.1 \quad$ OBJETIVO GERAL

Analisar o sistema logístico em serviços de saúde, relacionado aos hospitais, públicos e privados, no município de São Paulo. OBJETIVOS ESPECÍFICOS

Identificar a existência de indicadores logísticos nas organizações hospitalares pesquisadas.

Identificar iniciativas de utilização de serviço enxuto e de logística enxuta.

Identificar e analisar se o sistema logístico dos hospitais pesquisados reflete a adoção da logística enquanto estratégia de gestão. 


\section{MÉTODO}

Este capítulo delineia os procedimentos metodológicos a serem utilizados tanto na coleta como na análise e interpretação dos dados, com a finalidade de auxiliar a análise do sistema logístico das organizações hospitalares.

Considerando as características do estudo, CRESWEL (1994) ressalta a importância da abordagem qualitativa ao mostrar que esta se preocupa mais fortemente com o processo do que com os resultados.

Essa abordagem, para MAZZOTTI e GEWANDSZNAJDER (1999), aplica-se às situações complexas ou particulares, tal como organizações hospitalares, públicas e privadas, nas quais se pretende analisar um processo dinâmico e de mudança de gestão em saúde para explicar relações que regulam o funcionamento de uma estrutura. E, também, pelo fato de se trabalhar com aspectos subjetivos, como valores, concepções de gestão, visão do processo tecnológico, cooperação, organização de arranjos produtivos e escolha de estratégias organizacionais, entre outros, que são de difícil mensuração.

Esta pesquisa adota a abordagem qualitativa, com o propósito do entendimento do ambiente estudado que é complexo e possui certas particularidades e, a partir daí destacou a caracterização e desempenho logístico nas organizações hospitalares.

\subsection{ESTRATÉGIA DA PESQUISA}

Adotou-se como estratégia de pesquisa o estudo de casos múltiplos. Os cinco casos estudados se referem a hospitais, públicos e privados, localizados no município de São Paulo. 
Este estudo contempla os três pontos básicos a serem considerados para a determinação do método de realização de uma pesquisa, segundo YIN (2001). A questão básica, proposta nesta pesquisa é a análise (caracterização/desempenho) do sistema logístico nos serviços de saúde, ou seja, "como" e "por que" da implementação. O controle da pesquisadora é nulo e o foco é a situação atual e suas perspectivas. Dessa forma, entende-se como apropriado o método do estudo de caso.

O estudo de caso objetiva a obtenção do conhecimento aprofundado de uma realidade delimitada, neste caso os hospitais públicos e privados, e trata de um fenômeno contemporâneo, qual seja a implementação da estratégia de logística e supply chain, no contexto de situação real. (TRIVINÕS, 1990; YIN, 2001).

O estudo foi realizado em cinco hospitais, de grande porte, sendo três deles, privados e dois públicos, que representam atendimentos de média e alta complexidades, escolhidos por terem apresentado alguma ação na área de logística.

\subsubsection{Limitação}

A maior limitação do estudo de caso qualitativo é a de não permitir generalizar os resultados da pesquisa para a população, da qual se extraiu a amostra por critérios de interesse, mas permite a transferibilidade para organizações hospitalares com diagnóstico semelhante. Os estudos apresentados neste trabalho, mostram-se em pequeno número e o seu objetivo de uso é a replicação e não a sua generalização.

Outra limitação foi o prazo de execução e o tempo despendido nos processos de submissão até a aprovação do projeto aos diversos comitês de ética em pesquisa. 


\subsection{UNIDADES DE ANÁLISE}

As unidades de análise, neste estudo, referem-se a hospitais, públicos e privados, localizados no município de São Paulo, que atuam na assistência de média e alta complexidades.

A amostra, determinada de forma não-probabilística, foi definida pelos critérios de relevância, porte da organização, caráter inovador, participação no mercado (público ou privado) do setor saúde; e facilidade de acesso pela aceitação em participar da pesquisa.

A seleção dos hospitais pode ser justificada, segundo SELLTIZ et al. (1975), por permitir que os componentes da amostra estejam de acordo com as características estabelecidas como necessárias para agrupar casos típicos, neste estudo, os hospitais, públicos e privados que se notabilizaram pela reconhecida qualidade dos serviços prestados, e por apresentarem, segundo profissionais da área ou anúncios publicados na mídia ou prêmios recebidos, o desenvolvimento de ações, mesmo que em iniciativas pontuais, na área de logística.

Caracterização dos hospitais em estudo:

\section{PÚBLICOS}

Hospital das Clínicas da Faculdade de Medicina da Universidade de São Paulo (HCFMUSP): Instituto Central (ICHC) 
O HCFMUSP é uma entidade autárquica do Governo do Estado de São Paulo, vinculada à Secretaria de Estado da Saúde de São Paulo para fins de coordenação administrativa e associada à Faculdade de Medicina da Universidade de São Paulo, para fins de ensino, pesquisa e prestação de ações e serviços de saúde de alta complexidade destinados à comunidade.

A construção do Hospital das Clínicas foi planejada desde 1915 com a assinatura de um convênio entre o Governo do Estado de São Paulo e a Fundação Rockefeller, para a edificação da sede da Faculdade de Medicina e Cirurgia de São Paulo, que foi fundada em 1912. Fazia parte do acordo a construção de um hospitalescola para o aprimoramento dos estudantes e assistência médica gratuita à população carente da capital e do interior do Estado e, também, de outros Estados.

Em 1938 foi iniciada a construção do Hospital das Clínicas da Faculdade de Medicina da Universidade de São Paulo - HCFMUSP. Segundo a classificação do Ministério da Saúde é definido como hospital tipo III, que se refere aos hospitais gerais que contam com recursos tecnológicos e humanos adequados para o atendimento geral de urgências e emergências, desempenhando ainda atribuições de capacitação, aprimoramento e atualização dos recursos humanos (MINISTÉRIO DA SAÚDE, 1999). Enquanto hospital de ensino é uma unidade de saúde capaz de prestar serviços altamente especializados à população, com qualidade e tecnologia de ponta. É, também, importante centro de formação e desenvolvimento de recursos humanos, desempenhando papel de destaque na região em que está inserido.

O Hospital das Clínicas foi criado pelo Decreto 13.192, de 19 de janeiro de 1943, e sua inauguração oficial aconteceu em 19 de abril de 1944. Foi projetado para atuar em ensino, pesquisa e assistência no âmbito das ciências médicas, concentrando todas as especialidades, como apoio ao desenvolvimento da prática da Faculdade de Medicina da Universidade de São Paulo, FMUSP.

Em 1944 dispunha de 1.047 leitos distribuídos em 11 andares e sua organização era constituída pelo Conselho de Administração, Superintendência, 
Divisão Médica, Divisão de Serviços Técnicos e Divisão Administrativa. A expansão do Instituto Central propiciou a criação dos demais Institutos que atualmente compõem o Sistema HC. O Prédio dos Ambulatórios, PAMB, foi agregado ao ICHC em 1979, para atender aos acidentes externos nos seus ambulatórios de especialidades e, dessa forma, é considerado como parte do ICHC.

\section{Instituto Central do Hospital das Clínicas da FMUSP (ICHC} FMUSP):

Hospital público, geral, com fundação de apoio - Fundação Faculdade de Medicina (FFM) - vinculado ao Hospital das Clínicas da Faculdade de Medicina da Universidade de São Paulo, com mais de 500 leitos, corpo clínico próprio e integrado pelo quadro de docentes da Universidade de São Paulo. Em 2007 atendeu, no ambulatório uma clientela SUS de $94 \%$ e $6 \%$ de convênio e particular, e disponibilizou $5 \%$ dos leitos para convênio e particular. Desempenha também atividades de ensino e pesquisa (RELATÓRIO DE GESTÃO, 2007).

Atualmente, o ICHC dispõe de quase $50 \%$ dos leitos existentes no Sistema Hospitalar HCFMUSP; cerca de 960, dos quais 118 de UTI - Unidade de Terapia Intensiva. É considerado hospital de excelência e referência na assistência, ensino e pesquisa, e pioneiro em muitos procedimentos médico-hospitalares. A área física total é de $161 \mathrm{mil} \mathrm{m}^{2}$ e compreende várias salas de aula para residentes e aprimorandos de diversas áreas da saúde, 52 salas cirúrgicas, além de outras unidades.

O Instituto Central do HCFMUSP é composto por 70 unidades administrativas, com 5.737 colaboradores representados em 139 funções diversas: 62 de nível superior, com 2178 colaboradores; 62 de nível médio, com 2841 colaboradores e 15 de nível elementar, com 718 colaboradores. Além desses, o ICHC soma à força de trabalho a equipe de empresas terceirizadas, constituindo 502 pessoas; 430 que atuam na área de Limpeza e Higiene Hospitalar, 24 em atividades de portaria e recepção e 48 na área de vigilância. 


\section{- Instituto Dante Pazzanese de Cardiologia - IDPC}

Hospital público de especialidade e de ensino, de grande porte, para doenças cardiovasculares de alta complexidade. Com corpo clínico próprio e com fundação de apoio - Fundação Adib Jatene - FAJ, conta com 310 leitos operacionais e emprega aproximadamente 1.800 funcionários.

O Instituto de Cardiologia do Estado de São Paulo foi criado em 1954, pela lei 2552, iniciando suas atividades no ano seguinte, na Av. Paulista, 392.. Em 1958 seu funcionamento foi transferido para o atual endereço, Av. Dr. Dante Pazzanese, 500. Em 1975, pela Lei 782, passou a denominar-se Instituto Dante Pazzanese de Cardiologia em homenagem ao seu fundador e primeiro diretor Dr. Dante Pazzanese.

No ano de 1985 foi criada a Fundação Adib Jatene, de direito privado, sem fins lucrativos, com a finalidade de dinamizar a administração do Instituto e principalmente, como instrumento de apoio à pesquisa e ao ensino da Cardiologia e, da Cirurgia Cardiovascular. Em 2000, a Fundação passou a ser entidade filantrópica.

O Hospital destaca-se pela assistência cardiológica clínica e cirúrgica, técnicas diagnósticas e terapêuticas e realização de pesquisas pioneiras, que resultaram em técnicas importantes, como a cirurgia para Correção Anatômica das Grandes Artérias, designada Cirurgia de Jatene; Reconstrução Geométrica do Aneurisma de Ventrículo Esquerdo, e, atualmente, a utilização de Stents Recobertos com Fármacos para prevenir reestenoses em artérias coronárias.

Outro aspecto é a realização de Cirurgia Experimental, em parceria com o Centro Técnico de Pesquisas e Experimentos de Bioengenharia, o que possibilitou o desenvolvimento e a produção de aparelhos e instrumentais de grande utilidade em cardiologia e angiologia, propiciando os primeiros marcapassos, próteses valvares, desfibriladores e máquinas para circulação extracorpórea fabricados no país. 
O Hospital é uma das 80 (oitenta) organizações hospitalares brasileiras acreditadas segundo a metodologia da Organização Nacional de Acreditação (ONA), entre os níveis de qualificação - acreditada, acreditada pleno, e acreditada com excelência. Seu nível de qualificação é Acreditado.

\section{PRIVADOS}

\section{$>$ Hospital Israelita Albert Einstein - HIAE}

Hospital privado da alta tecnologia, sem fins lucrativos, com aproximadamente 500 leitos operacionais. Com corpo clínico aberto, iniciou suas atividades em 1971. É integrante da Sociedade Beneficente Israelita Brasileira Albert Einstein (SBIBAE), uma instituição sem fins lucrativos voltada para a assistência à saúde, à geração do conhecimento e à responsabilidade social, fundada em 1955. O nascimento da SBIBAE, na década de 1950, resultou do compromisso da comunidade judaica em oferecer à população brasileira uma referência em qualidade da prática médica.

O Hospital realiza cerca de 70 cirurgias diárias e 250 partos mensais. Foram realizados em 2006, nas unidades do Albert Einstein Medicina Diagnóstica, 1,8 milhão de exames. Nesse ano também foram feitos 215 transplantes, sendo que $90 \%$ pelo SUS.

Atualmente, a SBIBAE realiza projetos na parceria público-privada, dentre eles transplantes pelo SUS, Banco de Cordão umbilical e placentário, Programa saúde da família, Assistência Médica Ambulatorial, Exames Laboratoriais, Consultórios de Ultra-sonografia, Centros de Oftalmologia, Exames de Eletroneuromiografia e Eletroencefalografia. 
O HIAE obteve a acreditação da Joint Commission International em 1999, e a mantém por meio das novas avaliações. Adotou uma abordagem sistemática para minimizar o impacto de suas atividades no meio-ambiente e obteve, como reconhecimento de seu compromisso com o desenvolvimento sustentável, a certificação ISO 14001:1996. Paralelamente, vários Departamentos obtiveram a certificação do Sistema de Gestão da Qualidade ISO 9001:2000.

\section{$>$ Hospital Samaritano de São Paulo}

Hospital privado e sem fins lucrativos, inaugurado em 25 de janeiro de 1894. O Hospital nasceu da generosidade de um imigrante que, ao ser discriminado por sua crença religiosa em um hospital da cidade de São Paulo, decidiu doar seu patrimônio para que fosse construído um hospital que contemplasse como princípio básico o atendimento sem discriminação a todo paciente, independente de raça, credo, cor e condição social.

Houve interesse de três comunidades de imigrantes - britânicos, norteamericanos e alemães - pelo projeto, apoiado por tradicionais famílias paulistas. Foi construído um prédio que funcionou por muitos anos, onde eram atendidas especialidades clínicas, cirúrgicas, pediátricas e obstétricas. No início dos anos de 1970 foi construído outro edifício, com instalações mais modernas e infra-estrutura apropriada para os tempos mais recentes. Na década de 1980 mais um prédio foi construído para abrigar, inicialmente, mais enfermarias, e posteriormente um conjunto de consultórios. Nos anos 1990 novas alterações ocorreram no hospital. Modernizações e reformas são constantes para prover acomodações adequadas em termos de conforto e segurança aos clientes, familiares e acompanhantes.

O hospital conta com 208 leitos operacionais, em estrutura física de apartamentos individualizados, Unidade de Terapia Intensiva de adultos, pediátrica e neonatal. Os serviços de apoio diagnóstico e terapêutico são na maioria terceirizados. Os serviços de lavanderia, nutrição, telefonia, manutenção e obras também estão terceirizados. 
O Corpo Clínico, aberto, é composto por 1800 médicos; 200 deles são considerados parceiros do hospital por serem os profissionais que mais internam pacientes e mais utilizam os serviços da Instituição.

Nos anos de 1990, uma empresa de consultoria foi contratada para fazer um diagnóstico da situação e propor melhorias que trouxessem ao hospital um diferencial competitivo. Após o levantamento e análise da situação, a empresa apresentou um relatório com as ações a serem implementadas. O Hospital entendeu que não era o momento de iniciar o processo de mudança sugerido, porém, no final da década de 1990 outra empresa, com base nos resultados apresentados pela primeira, iniciou um planejamento estratégico. Definiu-se, então, a missão, a visão e os valores do hospital e as diversas ações que têm sido implementadas, de acordo com um cronograma pré-definido, ajustado a cada dois anos, para adequá-lo às exigências ocorridas no ambiente externo e às necessidades e expectativas dos clientes.

Novos processos foram introduzidos, com base nas orientações fornecidas pela consultoria e por um órgão de acreditação a quem o hospital se filiou para apresentar evidências da qualidade dos serviços oferecidos aos clientes. Em dezembro de 2004 o Hospital recebeu o certificado de acreditação da Joint Commission International (JCI).

$>$ Hospital Sírio Libanês - HSL

Hospital privado da alta tecnologia, sem fins lucrativos, com aproximadamente 300 leitos em operação. Sua história teve início no ano de 1921, quando um grupo de senhoras da comunidade sírio-libanesa fundou a Sociedade Beneficente de Senhoras do Hospital Sírio Libanês, com o intuito de angariar fundos para a construção de um hospital que atendesse à população de todas as classes sociais e estivesse à altura da cidade de São Paulo.

Com o apoio financeiro de um grupo de doadores, o HSL começou a ser construído em 1931, num terreno de aproximadamente 17 mil metros quadrados, 
situado à Rua da Fonte, com término do prédio original em 1940. Três anos depois foi desapropriado, por ordem do interventor de São Paulo, para abrigar a Escola Preparatória de Cadetes, e foi devolvido à Sociedade Beneficente em 1959.

Integrante da Sociedade Beneficente de Senhoras, o Hospital reiniciou suas atividades em 1962. Em 1965 deu-se a inauguração oficial do Hospital SírioLibanês, com capacidade para 35 leitos logo ampliada para 60 leitos. O ano de 1971 marcou a inauguração de um prédio de dez andares, com capacidade para 100 apartamentos; da primeira UTI do Brasil, com dez leitos; e do serviço de radiologia. Em 1978 foi criado o CEPE - Centro de Estudos e Pesquisas e em 1992 o Centro de Transplantes de órgãos e a Unidade de Oncologia.

Atualmente, com 100 mil metros quadrados de área construída, cerca de 4,5 mil colaboradores - entre funcionários, equipe de enfermagem e médicos, o HSL possui capacidade para realizar até 50 cirurgias por dia, cerca de dois mil tipos de exames diagnósticos e acolher 300 pessoas em seus leitos.

\subsection{TÉCNICAS PARA COLETA DE DADOS}

Para desenvolver o estudo de campo foram utilizadas as técnicas: entrevista semi-estruturada, com o objetivo de obter junto aos gestores e responsáveis pela área de logística, informações importantes relacionadas ao sistema logístico das organizações pesquisadas; pesquisa documental, para corroborar com a coleta de informações, e observação direta, pela visita de campo e foram utilizados os mesmos instrumentos de coleta de informações para todos os hospitais. (YIN, 2001; LAKATOS \& MARCONI, 2002).

Foram realizadas entrevistas junto aos diretores/gestores hospitalares/ gerentes, nas áreas de logística, farmácia e enfermagem, tomadores de decisão nos níveis estratégico, tático e operacional na implementação do conceito de logística no ambiente hospitalar. 
As informações documentais são relevantes e podem corroborar as informações obtidas em outras fontes. Foram solicitados documentos recentes, como o Organograma da Organização, Plano Diretor, Relatório de Gestão, Balancetes, Relatórios referentes à gestão de estoques e Estatuto da organização.

Os roteiros de entrevista e de visita foram submetidos a pré-teste, para possibilitar adequação e melhor formulação das questões. O período de realização do estudo de campo envolveu quatro meses do ano de 2008, incluindo entrevistas e visitas aos hospitais selecionados.

\subsection{ESTUDO DE CAMPO E ASPECTOS RELEVANTES}

\subsubsection{Entrevista semidiretiva}

- Perfil do Respondente

- Escolaridade; faixa etária; sexo; cargo; tempo de trabalho na organização; área de atuação.

- Estratégia da organização

- Estratégia de Suprimentos

- planejamento de suprimentos; relacionamento com os fornecedores; integração com os fornecedores; avaliação dos fornecedores; e-procurement; padronização; interface dos profissionais de saúde na demanda; integração na distribuição interna.

- Canal de distribuição (dispensação) 
- planejamento; posicionamento logístico de atendimento da demanda; distribuição interna e externa; distribuição física.

- Logística reversa

- iniciativas de reutilização, reuso, reaproveitamento; plano de gerenciamento de resíduos do hospital;

- retorno dos materiais e medicamentos não utilizados.

- Integração Estratégica

- planejamento e execução; fluxo financeiro e de materiais; fluxo de informação; tomada de decisão; sistemas informatizados; gargalos entre faturamento e pagamento.

- Fator Humano

- critérios de contratação; profissionais de logística; capacitação.

- Terceirização e Outsourcing

- serviços terceirizados; critérios de avaliação para contratação e sistema de avaliação; indicadores de avaliação de qualidade e indicadores de desempenho utilizados.

- outsourcing dos serviços logísticos

- Inovação Tecnológica e Tecnologia da Informação

- sistema de informação (informatização) utilizado; critérios na tomada de decisão; rastreabilidade.

- Mentalidade enxuta e a logística hospitalar

- níveis de estoque; tempo de atendimento do pedido; desintermediação; enfoque sistêmico; mentalidade dos gestores. 
- iniciativas de implementação de ações de serviço enxuto.

- Desempenho Logístico

- indicadores logísticos utilizados formalmente ou informalmente nas organizações a serem estudadas.

\subsubsection{Pesquisa Documental}

- Perfil e porte da organização

- Natureza jurídica; natureza do capital; faturamento anual; fonte de financiamento (SUS; convênios; particular; outro); principais convênios que atende; patrimônio líquido; localização; área construída e área total; número de colaboradores (próprios, temporários e terceirizados); relação dos hospitais administrados pela mantenedora.

- Performance da organização

- produção segundo especialidade;

- discriminação das receitas e das despesas (documentos oficiais);

- evolução do quadro de RH;

- número de unidades administradas pela mantenedora;

- investimentos na área de logística.

- Documentos oficiais e relatórios solicitados às organizações:

- Plano Diretor; Plano Operativo; Relatório de Gestão; Organograma; Projeto ou Plano logístico. 
- Relatórios de Estoque - Classificação ABC, XYZ; Custos logísticos; Custo ABC.

\subsection{ANÁLISE DOS DADOS}

Os dados foram compilados em banco de dados SPHINX e Excell ${ }^{\mathrm{TM}}$ para facilitar a organização e a interpretação e estão apresentados sob a forma de quadros, tabelas e figuras.

Aos dados primários, coletados por meio das entrevistas semiestruturadas com escalas do tipo Likert, ímpar com cinco variáveis, inicialmente calculam-se as estatísticas descritivas do banco de dados e faz-se análise de frequência.

Para cada uma das afirmações apresentadas, o entrevistado foi convidado a manifestar-se quanto à opção feita, considerando o contexto hospitalar e as circunstâncias encontradas.

A análise de conteúdo, enquanto técnica que descreve e sistematiza, que se utiliza do cálculo de freqüência do conteúdo manifesto, e que também considera contexto e circunstâncias, foi utilizada na interpretação dos dados apresentados. (BARDIN, 1977; MINAYO, 2000; BERELSON, 1971).

\subsection{PRINCÍPIOS ÉTICOS}

$\mathrm{O}$ projeto de pesquisa foi submetido aos comitês de ética em pesquisa dos diferentes hospitais e da Faculdade de Saúde Pública da Universidade de São Paulo. Foi obtido o consentimento informado e esclarecido de todos os entrevistados. 
O estudo contemplou os princípios estabelecidos em ética em pesquisa com seres humanos, no compromisso da divulgação de dados, informações e resultados obtidos, de forma agregada, sem identificar as pessoas e as organizações participantes na apresentação dos resultados. 


\section{ANÁLISE E DISCUSSÃo DOS RESULTADOS}

Este capítulo apresenta os resultados obtidos por meio das entrevistas semi-estruturadas junto aos executivos dos hospitais, dos documentos fornecidos e das visitas de observação.

A análise inicia-se com a caracterização das organizações pesquisadas e destaca os aspectos gerais, natureza jurídica, porte e nível de atenção. A seguir apresentam-se a natureza do capital, faixa do faturamento anual, patrimônio líquido, fontes de financiamento e principais convênios atendidos.

O capítulo prossegue com a apresentação dos resultados das entrevistas. Os dados referentes às questões fechadas são demonstrados em forma de tabelas e os percentuais são calculados com base nos valores absolutos. Em seguida são apresentadas as informações dos participantes em relação a cada tópico e as observações não-participante registradas durante a pesquisa de campo.

Para resguardar a identidade dos entrevistados e manter as condições de confidencialidade acordadas foram substituídos os nomes, que estão representados por E1, E2, E3, E4, E5, E6, E7, E8, E9, E10, E11, E12, E13, E14 e E15 e os hospitais, identificados por HA, HB, HC, HD e HE.

\subsection{PERFIL DAS ORGANIZAÇÕES ESTUDADAS}

Foram solicitadas aos hospitais estudados informações a respeito do perfil da instituição, considerando como identificação: instituição pública; pública com fundação de apoio; e instituição privada; caracterização dos serviços prestados como geral ou de especialidade; nível de atenção à saúde prestada pelo hospital, 
observando quanto à atenção: secundária, terciária ou quaternária; porte do hospital: pequeno, médio, grande ou especial, apresentados na Tabela 1. Também identifica a faixa de faturamento, patrimônio líquido, fontes de financiamento e os principais convênios atendidos.

Tabela 1 - Perfil dos Hospitais

\begin{tabular}{llll}
\hline Natureza Jurídica & $\begin{array}{l}\text { Característica } \\
\text { Assistencial }\end{array}$ & Porte & $\begin{array}{l}\text { Nível de } \\
\text { Atenção }\end{array}$ \\
\hline $\begin{array}{l}\text { Público com } \\
\text { Fundação de Apoio }\end{array}$ & Especializado & Grande & Quaternário \\
$\begin{array}{l}\text { Público com } \\
\text { Fundação de Apoio }\end{array}$ & Geral & Especial & Quaternário \\
Privado & Geral & Grande & Terciário \\
Privado & Geral & Grande & Quaternário \\
Privado & Geral & Grande & Quaternário \\
\hline
\end{tabular}

Fonte: Dados da Pesquisa

Dos cinco hospitais da amostra, observou-se que ambos os hospitais públicos contam com fundação de apoio, disponibilizam atendimentos ambulatoriais e de internação e são reconhecidos como referência nacional e internacional, de alta complexidade e desenvolvem também atividades de ensino e pesquisa. Quanto à característica assistencial, diferenciam-se em especial, e geral. Em relação ao porte, um é considerado grande e o outro especial.

Em relação aos privados, caracterizam-se como gerais, de alta complexidade e tecnologia; de grande porte, com mais de 260 leitos operacionais, reconhecidos como referências nacional e internacional. Dessas organizações, duas delas desenvolvem atividades de ensino e pesquisa.

Outra característica dos hospitais em estudo é quanto à preocupação em relação à qualidade dos serviços prestados, pois todos estão acreditados: os privados 
estão acreditados por instituição internacional e os públicos, com fundação de apoio, certificados por instituição nacional.

Quanto à faixa de faturamento anual e faixa do patrimônio líquido, como a pesquisa foi realizada durante o ano de 2008 foram tomados, por base, os dados do exercício 2007.

Tabela 2 - Faixa de Faturamento

\begin{tabular}{lcc}
\hline $\begin{array}{l}\text { FATURAMENTO } \\
\text { (em milhares de reais) }\end{array}$ & $\mathrm{N}$ & $\%$ \\
\hline Até 100.000 & - & - \\
De 101.000 a 300.000 & 1 & 20,0 \\
De 301.000 a 500.000 & 1 & 20,0 \\
De 500.000 a 800.000 & 2 & 40,0 \\
De 800.000 a 1.000 .000 & - & - \\
Acima de 1.000 .000 & 1 & 20,0 \\
\hline TOTAL & 5 & 100,0 \\
\hline
\end{tabular}

Fonte: Dados da pesquisa

Nos hospitais privados o atendimento aos convênios é o principal componente das receitas oriundas do faturamento. Nos hospitais públicos é inversamente proporcional: os atendimentos SUS representam em torno de $95 \%$ do total e os convênios e particular representam aproximadamente $6 \%$ dos atendimentos. Os hospitais públicos estudados contam com fundação de apoio e o sistema atual não contempla a integração estratégica da gestão do fluxo financeiro referente a convênios e particular.

Dos hospitais pesquisados, $60 \%$ apresentaram patrimônio líquido no ano de 2007 , superior a R $\$ 1.000 .000$ milhares, e os demais $40 \%$, subdividem-se em $20 \%$ 
na faixa de R\$ 500.000 a R\$ 800.000 milhares e $20 \%$ na faixa de R\$ 101.000 a R\$ 300.000 milhares.

Tabela 3 - Faixa do Patrimônio Líquido

\begin{tabular}{lcc}
\hline $\begin{array}{l}\text { PATRIMÔNIO LÍQUIDO } \\
\text { (em milhares de reais) }\end{array}$ & N & $\%$ \\
\hline Até 100.000 & - & - \\
De 101.000 a 300.000 & 1 & 20,0 \\
De 301.000 a 500.000 & - & - \\
De 500.000 a 800.000 & 1 & 20,0 \\
De 800.000 a 1.000 .000 & - & - \\
Acima de 1.000 .000 & 3 & 60,0 \\
\hline TOTAL & 5 & 100,0 \\
\hline
\end{tabular}

Fonte: Dados da pesquisa

O perfil apresentado acima permite deduzir que as organizações em questão demonstram ter condições favoráveis para desenvolver uma gestão estratégica em saúde e contemplar princípios inovadores, dentre eles a estratégia logística que é defendida por alguns autores (BALLOU, 2001; CHRISTOPHER, 1997; MOURA, 2003; NOVAES, 2007).

\subsection{PERFIL DOS PARTICIPANTES}

Neste item, delineia-se o perfil social dos participantes deste estudo, referente a gênero, escolaridade, cargo, tempo de trabalho na organização, tempo no cargo atual e área de atuação. 
Quadro 1 - Perfil social dos Participantes

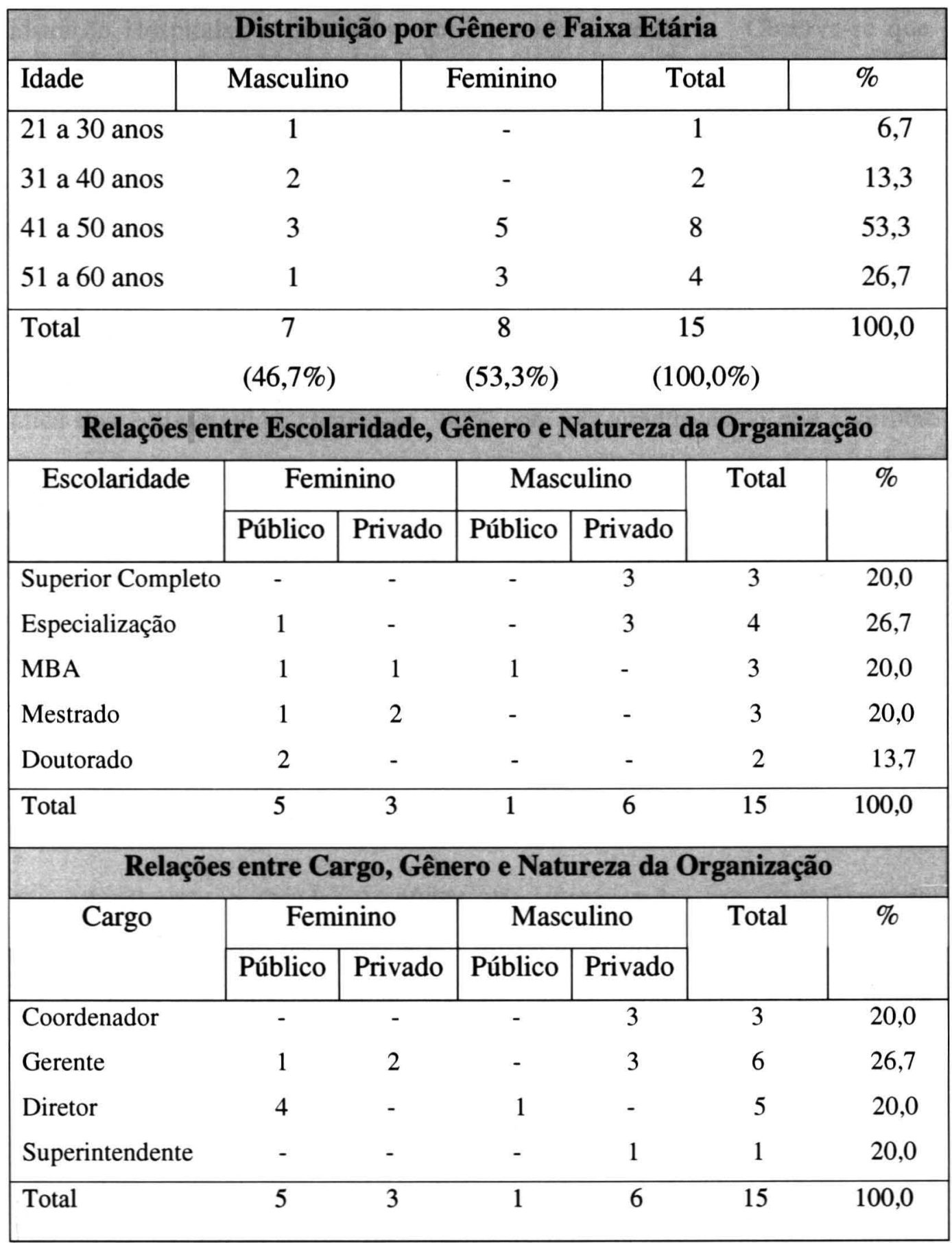

Fonte: Dados da Pesquisa

O Quadro 1 demonstra que, dos entrevistados, 53,3\% representam o gênero Feminino e $46,7 \%$ são do gênero Masculino, com predominância da faixa etária entre 41 a 60 anos, correspondendo a 80,0\% dos participantes. 
Dos entrevistados, 46,7\% concluíram especialização ou MBA na área de Administração Hospitalar, e um deles está cursando o mestrado. Observa-se que $13,3 \%$ dos respondentes são doutores, do gênero feminino, e da área de Enfermagem. Dos $20 \%$ com mestrado, todos são do gênero feminino - duas enfermeiras e uma farmacêutica - e uma delas está cursando o doutorado na Faculdade de Saúde Pública da Universidade de São Paulo.

Nota-se que as organizações estudadas contam com profissionais altamente qualificados em suas áreas de atuação. Ainda em relação à formação acadêmica dos entrevistados, somam-se $80 \%$ com pós-graduação, o que significa que fazem parte de um grupo seleto, que representa menos de $10 \%$ do total de colaboradores das organizações estudadas que compõem o grupo com pósgraduação, segundo documentos referentes a relatório de gestão do ano 2007, fornecidos pelos hospitais.

Quanto aos cargos dos participantes da pesquisa, observou-se que 46,7\% dos entrevistados representam colocação estratégica, reforçando a proposta de que a logística vem ocupando espaço diretivo nos hospitais estudados.

Analisando o Quadro 2, 40,0\% dos entrevistados que participam do processo de implementação da logística nos hospitais estudados, estão no cargo há um ano ou menos e cabe informar que não foram entrevistados dois novos responsáveis pela área estratégica de logística pelo motivo de terem sido contratados recentemente para o cargo.

É perceptível que a maioria dos ocupantes recentes do atual cargo está na organização há vários anos, demonstrando que as organizações estudadas possibilitam o crescimento na carreira profissional. Embora muito recentemente estejam contratando ou alterando os ocupantes dos cargos estratégicos de logística, têm incorporado os novos conceitos por meio de novas contratações e de oportunidade aos colaboradores da organização. 
Quadro 2 - Formação Acadêmica, Tempo de Trabalho no Hospital, Tempo de Trabalho no Cargo Atual e Área de Atuação.

\begin{tabular}{|llll|}
\hline $\begin{array}{l}\text { Formação } \\
\text { Acadêmica }\end{array}$ & $\begin{array}{l}\text { Tempo de trabalho } \\
\text { na Organização }\end{array}$ & $\begin{array}{l}\text { Tempo no cargo } \\
\text { atual }\end{array}$ & Área de atuação \\
\hline Administrador & 11 anos & - & Gestão Hospitalar \\
Economista & 6 anos & 2 meses & Planejamento Financeiro \\
Enfermeiro & 30 anos & 2 meses & Enfermagem Hospitalar \\
Farmacêutico & 29 anos & 8 anos & Farmácia Hospitalar \\
Médico & 5 anos & 5 anos & Gestão Hospitalar \\
Enfermeiro & 8 meses & 8 meses & Logística Hospitalar \\
Enfermeiro & 4 anos & 4 anos & Enfermagem Hospitalar \\
Administrador & 2 anos e meio & 2 anos e meio & Suprimentos \\
Enfermeiro & 23 anos & 2 anos & Enfermagem Hospitalar \\
Farmacêutico & 10 anos & 1 ano & Farmácia Hospitalar \\
Administrador & 25 anos & 4 anos & Suprimentos \\
Enfermeiro & 20 anos & 2 anos & Enfermagem Hospitalar \\
Farmacêutico & 18 anos & 4 anos & Farmácia Hospitalar \\
Engenheiro & 1 ano & 1 ano & Suprimentos \\
Tecnólogo em Logística & 16 anos & 1 ano & Suprimentos \\
\hline Fonte: Dados & & &
\end{tabular}

Fonte: Dados da Pesquisa

Durante a realização desta pesquisa observou-se que os representantes da direção de nível estratégico da área de logística foram alterados em quatro das cinco organizações estudadas: duas públicas e duas privadas.

Mesmo não tendo sido revisados estudos de gênero, a análise dos resultados permite deduzir que esta é uma dimensão social considerada na hierarquia de gerência dos hospitais, visto que nos privados há predominância do gênero masculino nos cargos estratégicos, apesar de no transcorrer da análise documental se encontrar como meta o incremento do gênero feminino. 


\subsection{ESTRUTURA ORGANIZACIONAL-}

Durante a visita às organizações estudadas foram solicitados os organogramas, com o intuito de conhecer a posição hierárquica da área de logística e suprimentos e sua importância na organização.

4.3.1 Formalidade no organograma quanto à logística

A Tabela 4 demonstra que $80,0 \%$ dos participantes reconhecem a formalização das atividades logísticas no organograma da organização; 13,3\% entendem que não há formalidade quanto à logística na estrutura organizacional do hospital e $6,7 \%$ não souberam responder.

Tabela 4 - Formalidade no organograma

\begin{tabular}{l|c|c|c|c|c|c}
\hline \multirow{2}{*}{} & \multicolumn{6}{|c|}{ HOSPITAIS } \\
\cline { 2 - 7 } & \multicolumn{2}{|c|}{ PÚBLICO } & \multicolumn{2}{c}{ PRIVADO } & \multicolumn{2}{c}{ TOTAL } \\
\cline { 2 - 7 } & $\mathrm{N}$ & $\%$ & $\mathrm{~N}$ & $\%$ & $\mathrm{~N}$ & $\%$ \\
\hline Sempre & 3 & 20,0 & 9 & 60,0 & 12 & 80,0 \\
Às vezes & - & - & - & - & - & - \\
Quase nunca & - & - & - & - & - & - \\
Nunca & 2 & 13,3 & - & - & 2 & 13,3 \\
Não sei & 1 & 6,7 & - & - & 1 & 6,7 \\
\hline TOTAL & 6 & 40,0 & 9 & 60,0 & 15 & 100,0 \\
\hline
\end{tabular}

Fonte: Dados da pesquisa. 
É unânime a compreensão da formalidade da área logística aos entrevistados que representam as organizações privadas. Para a metade dos participantes das organizações públicas não há formalização da área de logística na estrutura organizacional, o que contradiz ao apontado na literatura de que as companhias líderes possuem organizações logísticas formais há muito tempo. (CHRISTOPHER, 1997).

Em relação à estrutura organizacional, por meio da análise dos organogramas das organizações constantes no Anexo A (A.1; A.2; A.3; A.4; A.5) e visitas de campo, observa-se que nos hospitais públicos a área de logística está subordinada à diretoria de administração. Nos hospitais privados, os organogramas são mais recentes e contemplam cargos referentes às novas funções da área de logistica.

Dos hospitais privados, um dos participantes verbalizou que adota organograma matricial no desenvolvimento das atividades de logística "a área de farmácia reporta-se à direção do hospital e relaciona-se matricialmente com a área de suprimentos". Em outro hospital privado a área de farmácia está subordinada à Logística e suprimentos. Durante a pesquisa, outro se apresentou em fase de reestruturação da área de logística, em fase de estudos do novo organograma e implementação dos novos conceitos.

Em relação aos hospitais públicos observou-se, em um deles, que a área de farmácia ocupa nível estratégico no organograma, enquanto no outro está subordinada à área de Logística.

A estrutura organizacional matricial vem despertando interesse dos gestores à medida que cada vez mais enfrentam os desafios do gerenciamento por processos e a versão moderna desse tipo de estrutura vem com a nomenclatura de organização horizontal (BOWERSOX, CLOSS, 2001; MAXIMIANO, 2001). 
Na perspectiva do novo conceito de cadeia logística, muda a forma de gerenciamento das atividades, que passam a ser executadas de forma coordenada, ao invés de práticas gerenciais tradicionais baseadas na departamentalização, em que as organizações e seus componentes são tratados de forma fragmentada (BALLOU, 2001).

Os hospitais privados apresentam maior velocidade na implementação desse conceito e deduz-se que estão sendo pressionados pelo mercado a adotar novas formas de gestão uma vez que estão inserido no contexto atual de competitividade, apresentam o alto custo gerado pela complexidade da atividade e sofrem pressão por parte das seguradoras de saúde que os remuneram.

As estruturas e quadro de pessoal das organizações públicas, baseados em decretos ou leis, acabam demonstrando tendência mais centralizadora e encontram menos agilidade à implementação de novas formas de gestão de logística, mesmo quando da terceirização de parte das atividades logísticas. Outra questão que cabe apresentar, nesse ponto, é o sistema de orçamento, voltado para as atividades funcionais.

\subsubsection{Nível hierárquico da logística}

A maioria dos entrevistados afirma que as atividades de logística estão subordinadas à diretoria $(93,3 \%)$, significando que se compreende tratar-se de uma atividade que ocupa espaço na preocupação estratégica da organização. Embora $13,3 \%$ dos participantes não identificam as atividades logísticas no organograma (tabela 4), reconhecem, por outro lado, sua subordinação ao comando estratégico (tabela 5). 
Durante as visitas, observou-se estar ocorrendo nas organizações que alteraram recentemente suas estruturas organizacionais na implementação da estratégia da logística ou estão em fase de mudança, uma reformulação na área da farmácia - com transferência da subordinação da área assistencial, vinculada diretamente à diretoria geral ou à clínica médica, para a área de logística.

Tabela 5 - As atividades de logística estão subordinadas à diretoria

\begin{tabular}{l|c|c|c|c|c|c}
\hline \multirow{2}{*}{} & \multicolumn{6}{|c}{ HOSPITAIS } \\
\cline { 2 - 7 } & \multicolumn{2}{|c|}{ PÚBLICO } & \multicolumn{2}{c}{ PRIVADO } & \multicolumn{2}{c}{ TOTAL } \\
\cline { 2 - 7 } & $\mathrm{N}$ & $\%$ & $\mathrm{~N}$ & $\%$ & $\mathrm{~N}$ & $\%$ \\
\hline Sempre & 5 & 33,3 & 9 & 60,0 & 14 & 93,3 \\
Às vezes & - & - & - & - & - & - \\
Quase nunca & - & - & - & - & - & - \\
Nunca & 1 & 6,7 & - & - & 1 & 6,7 \\
Não sei & - & - & - & - & - & - \\
\hline TOTAL & 6 & 40,0 & 9 & 60,0 & 15 & 100,0 \\
\hline
\end{tabular}

Fonte: Dados da pesquisa.

Nas organizações, uma pública e uma privada, que apresentaram o processo gradativo de incorporação da logística ao longo da última década, a área de farmácia hospitalar responde diretamente ao diretor da instituição e interage em mesmo nível hierárquico com a área de suprimentos, demonstrando habilidades interdisciplinares dessas áreas. (CHRISTOPHER, 1997; BOWERSOX e CLOSS, 2001; BALLOU, 2007).

As organizações estudadas estão em processo de adaptação, modificando suas operações, processos e estruturas, em diferentes graus. No contexto do mundo globalizado, das políticas de saúde e da inserção do hospital nos serviços de saúde, a adaptação organizacional é uma habilidade que os gestores devem ter para entender, interpretar e implementar estratégias, conforme as necessidades de mudanças percebidas no seu ambiente. 


\subsection{ESTRATÉGIA DA LOGÍSTICA}

Considerando-se que a escolha de uma boa estratégia de logística exige os mesmos processos criativos inerentes ao desenvolvimento de uma boa estratégia corporativa e de que abordagens inovadoras podem proporcionar vantagens competitivas e foco no cliente, o Quadro 3 apresenta os objetivos da logística e sua relação com a estratégia das organizações, manifestados pelos executivos entrevistados.

Dos quinze participantes, nove apresentaram os objetivos da logística e apenas quatro explicaram a estratégia da organização que representam. É significativo que dos nove apenas três incluem explicitamente entre os objetivos da logística as necessidades dos pacientes, o que cabe discussão, uma vez que para alguns autores (MOURA, 2003; CHRISTOPHER, 1997) o cliente deve ser o foco determinante da estratégia da logística.

Nota-se certo grau de concentração no entendimento do objetivo da logística em suprir a demanda do hospital como principal foco. Ao apontarem a preocupação de manter o hospital com insumos disponíveis e suficientes para atender aos pacientes, pode-se afirmar que o objetivo da logística/SC no ambiente hospitalar tem como objetivo primeiro, a responsividade com alta disponibilidade de insumos médico-hospitalares.

A responsividade da logística/CS está na habilidade de responder amplos escopos em quantidades exigidas; atender lead-times (tempo entre a primeira atividade e a última de um processo de várias atividades) curtos; manejar uma grande variedade de itens; produzir produtos ou serviços inovadores e atender a um nível de serviço alto. (CHOPRA, MEINDL, 2003). 
Quadro 3 - Objetivos da Logística e estratégia da Organização

\begin{tabular}{|c|c|}
\hline \multicolumn{2}{|c|}{ HOSPITAL PÚBLICO } \\
\hline Objetivos da Logística & Estratégia da Organização \\
\hline "não pode faltar e não pode falhar" & \\
\hline $\begin{array}{l}\text { "prover o medicamento em tempo com horizontalização dos } \\
\text { estoques de acordo com a verba orçamentária integrada ao } \\
\text { planejamento financeiro". }\end{array}$ & \\
\hline
\end{tabular}

HOSPITAL PRIVADO

"a área de logística tem como principal objetivo a gestão dos estoques, garantir o abastecimento para que o cliente final seja atendido da melhor forma possivel" (E3)

"suprir as áreas fins com insumos de uso cotidiano e especial e sinaliza itens para cobrança". Precisa estar alinhado com os objetivos e com os projetos para correto desenho (fluxo) $e$ dimensionamento : humano (quantitativo e qualitativo), material (tipo e quantidade de mat/méd) e estrutural (localização e área fisica). (E4)

"otimização dos processos, focando na agilidade do atendimento, na disponibilidade do "material" de acordo com as necessidades dos pacientes". (E5)

"atender toda a demanda de suprimentos médicos hospitalares aos pacientes. Atender as necessidades da área assistencial e administrativa".

(E6)

"a estratégia está definida em diretrizes".

"uma das diretrizes é a sustentabilidade, com segurança para o paciente e a prática da Medicina Baseada em Evidência". 
"manter o Hospital com insumos ao custo que mantenha a

sustentabilidade do hospital". (E8)

"manter giro de estoque, nivel de serviço, obsolescência e lenta movimentação em níveis adequados conforme metas estabelecidas pelo Hospital". (E9)

"a logistica está integrada em toda a cadeia, o objetivo maior é rotatividade maior de todos produtos e quanto menor o estoque, você consegue investir em outras áreas e reduz o risco de

obsolescência e de vencimento. A redução dos estoques precisa estar acompanhando o nivel de serviço". (E10)

"prover os recursos materiais (mat/med) para o funcionamento da instituição, contribuindo com a excelência de qualidade" (E15) relaciona com estratégia do Hospital fazendo a seleção adequada dos itens em função da margem de lucro que altera dependendo do item".

"relaciona com a Estratégia da organização à medida que foca em qualidade, prazos, quando procura trazer inovações e quando está focada nas melhores práticas de gestão de suprimentos. Quando utiliza metodologias de custeio, de criticidade $(X Y Z)$ e de orçamento (cumprir diretrizes financeiras)".

Fonte: Dados da pesquisa. 
Ao mencionarem a sustentabilidade da organização e o uso de ferramentas de logística que permitam velocidade e redução de custos, os entrevistados remetem-se à logística/CS eficiente, que tem como objetivo principal (CHOPRA, MEINDL, 2003; CHRISTOPHER, 1997) suprir a demanda com o menor custo.

A situação, na realidade, é muito dinâmica e complexa; os gestores hospitalares ao decidirem por alta disponibilidade de estoques, em termos gerais, conferem às organizações que representam uma prática de logística/CS mais responsiva, porém, por outro lado, acabam reduzindo a eficiência. É perceptível que nas organizações privadas em estudo, o desafio de estabelecer e alcançar o equilíbrio entre responsividade e eficiência em logística/CS, para atender às necessidades de suas estratégias competitivas, faz-se presente.

No momento em que os planos diretores das organizações privadas não foram disponibilizados para este estudo, utilizou-se a visão e a missão de cada uma das unidades analisadas, deduzindo, a partir daí, possíveis estratégias utilizadas pelas organizações.

Dos documentos cedidos, nenhum deles se refere explicitamente aos objetivos da logística e sua relação com a estratégia da organização, levando, portanto, a creditar aos entrevistados que o objetivo da logística resume-se em suprir toda a demanda do hospital de acordo com as necessidades dos pacientes e das diretrizes da organização, garantindo segurança, qualidade, inovação, prazo e custo. 


\section{Quadro 4 - Visão e missão das organizações estudadas}

\begin{tabular}{|c|c|c|c|c|c|}
\hline $\begin{array}{c}\mathrm{V} \\
\mathrm{I} \\
\mathrm{S} \\
\tilde{\mathrm{A}} \\
\mathrm{O}\end{array}$ & $\begin{array}{l}\text { Ser líder e } \\
\text { inovadora na } \\
\text { assistência } \\
\text { médico- } \\
\text { hospitalar, } \\
\text { referência na } \\
\text { gestão do } \\
\text { conhecimento e } \\
\text { reconhecida } \\
\text { pelo } \\
\text { comprometimento } \\
\text { com a } \\
\text { responsabilidade } \\
\text { social. }\end{array}$ & $\begin{array}{l}\text { Ser reconhecida } \\
\text { internacionalmente } \\
\text { pela excelência, } \\
\text { liderança e } \\
\text { pioneirismo em } \\
\text { assistência à saúde } \\
\text { e na geração de } \\
\text { conhecimento, } \\
\text { com } \\
\text { responsabilidade } \\
\text { social, ambiental e } \\
\text { auto- } \\
\text { sustentabilidade, } \\
\text { atraindo e retendo } \\
\text { talentos médicos e } \\
\text { colaboradores. }\end{array}$ & $\begin{array}{l}\text { Ser } \\
\text { reconhecido } \\
\text { pela } \\
\text { sociedade } \\
\text { como o } \\
\text { hospital que } \\
\text { supera as } \\
\text { expectativas } \\
\text { dos clientes. }\end{array}$ & $\begin{array}{l}\text { Ser um Hospital } \\
\text { Universitário líder } \\
\text { no País e Centro } \\
\text { de Excelência } \\
\text { internacionalmente } \\
\text { reconhecido, } \\
\text { maximizando } \\
\text { ações com } \\
\text { efetividade. }\end{array}$ & ND \\
\hline $\begin{array}{c}\mathrm{M} \\
\mathrm{I} \\
\mathrm{S} \\
\mathrm{S} \\
\tilde{\mathrm{A}} \\
\mathrm{O}\end{array}$ & $\begin{array}{l}\text { Oferecer } \\
\text { excelência de } \\
\text { qualidade no } \\
\text { âmbito } \\
\text { da saúde, da } \\
\text { geração do } \\
\text { conhecimento e } \\
\text { da } \\
\text { responsabilidade } \\
\text { social, como } \\
\text { forma de } \\
\text { evidenciar a } \\
\text { contribuição da } \\
\text { comunidade } \\
\text { judaica à } \\
\text { sociedade } \\
\text { brasileira. }\end{array}$ & $\begin{array}{l}\text { Ser um centro de } \\
\text { excelência } \\
\text { pioneiro e } \\
\text { de vanguarda na } \\
\text { assistência à } \\
\text { saúde, o } \\
\text { qual busca a } \\
\text { melhoria da } \\
\text { qualidade de } \\
\text { vida com calor } \\
\text { humano. }\end{array}$ & $\begin{array}{l}\text { Excelência } \\
\text { na } \\
\text { assistência à } \\
\text { saúde, com } \\
\text { atendimento } \\
\text { humanizado } \\
\text { e } \\
\text { compromisso } \\
\text { social. }\end{array}$ & $\begin{array}{l}\text { Formar e capacitar } \\
\text { profissionais de } \\
\text { saúde, produzir } \\
\text { conhecimento } \\
\text { científico e prestar } \\
\text { assistência } \\
\text { médico-hospitalar, } \\
\text { com sinergia entre } \\
\text { essas ações, } \\
\text { visando a saúde e } \\
\text { a qualidade de } \\
\text { vida. }\end{array}$ & ND \\
\hline
\end{tabular}

Fonte: Documentos das organizações: Balanço Social (2007); Relatório de Responsabilidade Corporativa (2007); Relatório de Gestão.

Nota: ND (não disponível).

\subsubsection{Logística e Vantagem Competitiva}

A literatura tem apontado que a competitividade depende de diversos fatores, mas que a excelência em logística tem se destacado como fonte de vantagens competitivas para permitir que as organizações melhorem seu desempenho 
(BALLOU, 2006; BOWERSOX e CLOSS, 2001; CHRISTOPHER, 1997; CHING, 2001).

A Tabela 6 traz a opinião dos participantes em relação à compreensão da logística/CS enquanto ferramenta estratégica que propicia vantagens competitivas nas organizações hospitalares, públicas e privadas.

Tabela 6-Compreensão da logística como estratégica de vantagem
competitiva
\begin{tabular}{l|c|c|c|c|c|c}
\hline \multirow{2}{*}{} & \multicolumn{6}{c}{ HOSPITAIS } \\
\cline { 2 - 7 } & \multicolumn{2}{|c|}{ PÚBLICO } & \multicolumn{2}{|c}{ PRIVADO } & \multicolumn{2}{c}{ TOTAL } \\
\cline { 2 - 7 } & $\mathrm{N}$ & $\%$ & $\mathrm{~N}$ & $\%$ & $\mathrm{~N}$ & $\%$ \\
\hline Às vezes & 2 & 13,3 & 8 & 53,3 & 10 & 66,6 \\
Quase nunca & - & - & 1 & 6,7 & 1 & 6,7 \\
Nunca & 1 & 6,7 & - & - & 1 & 6,7 \\
Não sei & - & - & - & - & - & - \\
Não resposta & 3 & 20,0 & - & - & 3 & 20,0 \\
\hline
\end{tabular}

Fonte: Dados da Pesquisa.

É importante a compreensão do conceito de logística enquanto ferramenta estratégica. A somatória dos setores público e privado corresponde a $66,6 \%$ das respostas.

Vale diferenciar que dentre nove dos executivos das unidades privadas, oito afirmam que "sempre" e um "às vezes" acontece, a logística estratégica no ambiente hospitalar em que atuam alavanca o diferencial competitivo. Em relação aos executivos das unidades públicas, apenas para dois em seis essa relação "sempre" acontece, e três deles não responderam. 
O setor hospitalar privado mostrou-se mais propicio a alavancar vantagens competitivas pela característica de encontrar-se num contexto atual de ambiente turbulento onde o foco é a própria sustentabilidade. Cabe lembrar que materiais e medicamentos no setor privado não representam somente gastos, mas uma fonte de receita oriunda da lucratividade da comercialização desses itens aos representantes da saúde supletiva, ao Governo, ou diretamente ao paciente.

Os sujeitos sociais compreendem que os hospitais em que trabalham confirmam o que os autores revisados informam em relação à vantagem competitiva, mas, ao mesmo tempo, nem todos os objetivos componentes e princípios do sistema logístico são encontrados nas falas dos entrevistados quando se referem à estratégia da organização.

Em relação aos objetivos da logística, percebe-se certo distanciamento entre a oralidade dos entrevistados e o previsto no quadro teórico pertinente ao assunto, ao não citarem a importância da integração e a logística reversa, e em apenas três das falas o paciente é lembrado.

\subsubsection{Evolução da função Logística/SC}

O conceito de CS (Cadeia de Suprimento) tem despertado interesse entre representantes dos mundos acadêmico e empresarial, apresentando uma evolução importante do que tradicionalmente se conhecia por logística ou administração de materiais.

A análise da Tabela 7, num primeiro momento, mostra a limitação das atividades de logística/CS ao ter como foco principal funções da logística 
tradicional, de estoque, armazenagem e processamento de pedidos, representando $86,6 \%$ das respostas; para $13,4 \%$ isso "às vezes" acontece.

Tabela 7 - Foco principal em estoque, armazenagem e processamento de pedido.

\begin{tabular}{l|c|c|c|c|c|c}
\hline \multirow{2}{*}{} & \multicolumn{6}{|c}{ HOSPITAIS } \\
\cline { 2 - 7 } & \multicolumn{2}{|c|}{ PÚBLICO } & \multicolumn{2}{c}{ PRIVADO } & \multicolumn{2}{c}{ TOTAL } \\
\cline { 2 - 7 } & $\mathrm{N}$ & $\%$ & $\mathrm{~N}$ & $\%$ & $\mathrm{~N}$ & $\%$ \\
\hline Sempre & 5 & 33,3 & 8 & 53,3 & 13 & 86,6 \\
Às vezes & 1 & 6,7 & 1 & 6,7 & 2 & 13,4 \\
Quase nunca & - & - & - & - & - & - \\
Nunca & - & & - & - & - & - \\
Não sei & - & & - & & - & - \\
\hline TOTAL & 6 & 40,0 & 9 & 60,0 & 15 & 100,0 \\
\hline
\end{tabular}

Fonte: Dados da pesquisa

No entanto, E15 evidencia que "não é só isso, logística é a inteligência do negócio. Como faço para a cadeia funcionar, para o negócio financeiramente funcionar e atender de forma adequada o assistencial? Preciso balancear finanças e assistência". E8 e E10 também se manifestam em relação à estratégia da logística na sustentabilidade do hospital e estabelecimento de parcerias, favorecendo a percepção do novo paradigma da logística.

Por outro lado, E12 informa que "armazenamos mat/méd [materiais e medicamentos] em vários pontos do hospital, em armários com caixas", citando que seriam "em mini-almoxarifados”, o que evidencia a prática da logística tradicional. 
Em relação à logística enquanto estratégia (Tabela 8), 46,7\% dos entrevistados afirmam que é uma atividade estratégica na organização que trabalham, confirmando a utilização dos conceitos atuais no ambiente hospitalar. Para 40\%, "às vezes" acontece e no entender de 13,3\%, isso "nunca" acontece. Para E8, "hoje há um entendimento no hospital do papel da logística é há também colaboração das demais áreas”. E11 coloca que é utilizada como estratégia e que há integração, porém acrescenta "embora seja informal".

Tabela 8 - Logística utilizada de forma estratégica e integrada em todos os setores do Hospital.

\begin{tabular}{l|c|c|c|c|c|c}
\hline \multirow{2}{*}{} & \multicolumn{6}{|c}{ HOSPITAIS } \\
\cline { 2 - 7 } & \multicolumn{2}{|c|}{ PÚBLICO } & \multicolumn{2}{c}{ PRIVADO } & \multicolumn{2}{c}{ TOTAL } \\
\cline { 2 - 7 } & $\mathrm{N}$ & $\%$ & $\mathrm{~N}$ & $\%$ & $\mathrm{~N}$ & $\%$ \\
\hline Sempre & 2 & 13,3 & 5 & 53,3 & 13 & 46,6 \\
Às vezes & 2 & 13,3 & 4 & 6,7 & 6 & 40,0 \\
Quase nunca & 2 & 13,3 & - & - & 2 & 13,3 \\
Nunca & - & & - & - & - & - \\
Não sei & - & & - & & - & - \\
\hline TOTAL & 6 & 40,0 & 9 & 60,0 & 15 & 100,0 \\
\hline
\end{tabular}

Fonte: Dados da pesquisa.

A evolução da logística passou por várias fases, conforme exposto na revisão da literatura. Atualmente abarca o conceito de Supply Chain e implica na extensão da sua abrangência para além das fronteiras da organização (BALLOU, 2001; CHRISTOPHER, 1997; CHING, 2001; NOVAES, 2007). Nesse sentido, a Tabela 9 expõe a visibilidade do hospital quanto à sua participação na cadeia de suprimentos no momento do planejamento. 
Tabela 9 - Visão do Hospital quanto à participação na Cadeia de Suprimentos

\begin{tabular}{l|c|c|c|c|c|c}
\hline \multirow{2}{*}{} & \multicolumn{5}{|c}{ HOSPITAIS } \\
\cline { 2 - 7 } & \multicolumn{2}{|c|}{ PÚBLICO } & \multicolumn{2}{c}{ PRIVADO } & \multicolumn{2}{c}{ TOTAL } \\
\cline { 2 - 7 } & $\mathrm{N}$ & $\%$ & $\mathrm{~N}$ & $\%$ & $\mathrm{~N}$ & $\%$ \\
\hline Sempre & 3 & 13,3 & 6 & 53,3 & 9 & 60,0 \\
Às vezes & - & - & 3 & 6,7 & 3 & 20,0 \\
Quase nunca & 2 & 13,3 & - & - & 2 & 13,3 \\
Nunca & - & - & - & - & - & - \\
Não sei & - & - & - & - & - & - \\
Não resposta & 1 & - & - & - & 1 & 6,7 \\
\hline TOTAL & 6 & 40,0 & 9 & 60,0 & 15 & 100,0 \\
\hline
\end{tabular}

Fonte: Dados da Pesquisa.

Em $60 \%$ das respostas "sempre" a organização enxerga a cadeia de suprimentos; para 33,3\%, a visão do hospital é míope em relação à sua participação em uma cadeia de suprimentos. Segundo E15, o hospital percebe sua participação não por opção: "saiu da zona de conforto por dificuldades na gestão do hospital e de suprimentos".

\subsubsection{Estratégia de Suprimentos}

Um dos sérios problemas de suprimentos na área hospitalar é a falta de medicamentos e materiais, que quando ocorre pode trazer consequências ao tratamento ou até mesmo à sobrevivência da pessoa enferma, comprometendo o sucesso/insucesso da atividade-fim da organização prestadora de serviços de saúde. 
Para $60 \%$ dos participantes realmente "às vezes" faltam medicamentos e materiais; $26,7 \%$ entendem que "quase nunca" ocorre e para $6,7 \%$ isso "nunca" acontece.

Tabela 10 - Falta de medicamentos e materiais hospitalares

\begin{tabular}{l|c|c|c|c|c|c}
\hline \multirow{2}{*}{} & \multicolumn{5}{|c|}{ HOSPITAIS } \\
\cline { 2 - 7 } & \multicolumn{2}{|c|}{ PÚBLICO } & \multicolumn{2}{c}{ PRIVADO } & \multicolumn{2}{c}{ TOTAL } \\
\cline { 2 - 7 } & $\mathrm{N}$ & $\%$ & $\mathrm{~N}$ & $\%$ & $\mathrm{~N}$ & $\%$ \\
\hline Sempre & 1 & 6,6 & - & - & 1 & 6,7 \\
Às vezes & 4 & 26,7 & 5 & 33,3 & 9 & 60,0 \\
Quase nunca & 1 & 6,7 & 3 & 20,0 & 4 & 26,7 \\
Nunca & - & - & 1 & - & 1 & 6,7 \\
Não sei & - & - & - & - & - & - \\
\hline TOTAL & 6 & 40,0 & 9 & 60,0 & 15 & 100,0 \\
\hline
\end{tabular}

Fonte: Dados da Pesquisa.

No campo observações, foram declarados os principais motivos das faltas e prevaleceu, para a maioria dos respondentes do setor privado, que ocorrem por problemas externos relacionados ao abastecimento no mercado ou, eventualmente, greve de órgãos que interferem na importação de materiais. E5 reconhece, além de problemas externos, que também ocorrem "saldo incorreto e consumo inesperado".

No setor privado, os respondentes afirmam com veemência que os problemas de abastecimento, tanto externos quanto internos, são contornados entre os profissionais que fazem parte da cadeia produtiva, e que há substituição de material ou de técnica cirúrgica, sem prejuízo do atendimento ao paciente.

No setor público, os motivos apresentados pelos respondentes foram relacionados principalmente a atrasos na entrega pelos fornecedores ou percalços no processo de compras. 
Tabela 11 - Suspensão de cirurgias por falta medicamentos e materiais

\begin{tabular}{l|c|c|c|c|c|c}
\hline \multirow{2}{*}{} & \multicolumn{9}{|c|}{ HOSPITAIS } \\
\cline { 2 - 7 } & \multicolumn{2}{|c|}{ PÚBLICO } & \multicolumn{2}{c}{ PRIVADO } & \multicolumn{2}{c}{ TOTAL } \\
\cline { 2 - 7 } & $\mathrm{N}$ & $\%$ & $\mathrm{~N}$ & $\%$ & $\mathrm{~N}$ & $\%$ \\
\hline Sempre & - & - & - & - & - & - \\
Às vezes & 4 & 26,7 & 1 & 6,7 & 5 & 33,0 \\
Quase nunca & 1 & 6,7 & 2 & 13,3 & 3 & 20,0 \\
Nunca & 1 & 6,7 & 5 & 33,3 & 6 & 40,0 \\
Não sei & - & - & - & - & - & - \\
\hline TOTAL & 6 & 40,0 & 9 & 60,0 & 15 & 100,0 \\
\hline
\end{tabular}

Fonte: Dados da Pesquisa.

Para 40\% dos executivos entrevistados não ocorre suspensão de cirurgias, ou outro procedimento, por motivo relacionado a suprimentos; $20 \%$ entendem que "quase nunca" acontece e 33,3\% afirmam que "às vezes" acontece. E3 informa que em relação à suspensão de cirurgia por falta de material "isso não acontece, é feito uma triagem do que será necessário para a cirurgia, também podemos oferecer materiais similares". E4 afirma que na "falta de algum produto no mercado, negocia-se um outro substituto". E6 repete a evocação de E4 e acrescenta que "altera a técnica cirúrgica".

Nas palavras de E8 "já ocorreu atraso na cirurgia por este motivo, mas ocorre o procedimento no mesmo dia, na falta de algum item específico, a equipe cirúrgica já precisou utilizar outra técnica porque faltou o tipo específico de material ou marca. Isso acontece principalmente quando se trata de itens importados, que apesar do produto ser atualmente encontrado no mercado local (anteriormente importado pelo hospital), porém, o produto continua sendo importado pela distribuidora”. 
Observou-se maior flexibilidade nos hospitais privados, pois quando há problema na cadeia de suprimentos há rápida comunicação e integração entre os membros da cadeia produtiva sem prejuízo à agenda do paciente.

Durante a pesquisa de campo, em um dos hospitais públicos observou-se que por falta de material foram suspensas as cirurgias programadas para serem realizadas naquela manhã. Presenciou-se uma relação de forte conflito entre os representantes da cadeia produtiva, com prejuízo aos pacientes e custos desnecessários.

\subsubsection{Relacionamento e Integração com os Fornecedores}

As organizações modernas estão se conscientizando cada vez mais da necessidade de estabelecer e manter alianças com fornecedores, o que vai exigir um relacionamento profissional entre compradores e vendedores muito mais próximo do que na prática tradicional.

A literatura apregoa (CHING, 1999; BOWERSOX, CLOSS, 2001; BALLOU, 2007) que na gestão estratégica da logística/SC uma das características é o estabelecimento de parceria com os fornecedores, contemplando a redução no número de fornecedores e maior colaboração entre os elos de fornecimento. A análise das entrevistas aponta que as organizações privadas atendem parcialmente essa proposta e as organizações públicas não se enquadram nessa característica.

Na percepção dos executivos, conforme demonstra a Tabela 12, apenas $13,3 \%$ confirmam que nos últimos anos houve redução no número de fornecedores; a somatória de "quase nunca" e "nunca" corresponde a 26,6\% das respostas, enquanto que $53,3 \%$ não sabem se houve ou não redução dos fornecedores, o que implica, de acordo com os autores pesquisados, na dedução de que não está consolidado o 
relacionamento de parcerias colaborativas em que se buscam resultados pela sinergia entre elos da cadeia produtiva no ambiente hospitalar.

Tabela 12 - Houve significativa redução dos fornecedores.

\begin{tabular}{l|c|c|c|c|c|c}
\hline \multirow{2}{*}{} & \multicolumn{5}{|c|}{ HOSPITAIS } \\
\cline { 2 - 7 } & \multicolumn{2}{|c|}{ PÚBLICO } & \multicolumn{2}{c}{ PRIVADO } & \multicolumn{2}{c}{ TOTAL } \\
\cline { 2 - 7 } & $\mathrm{N}$ & $\%$ & $\mathrm{~N}$ & $\%$ & $\mathrm{~N}$ & $\%$ \\
\hline Sempre & - & - & 2 & 13,3 & 2 & 13,3 \\
Às vezes & - & - & 1 & 6,7 & 1 & 6,7 \\
Quase nunca & 1 & 6,7 & 1 & 6,7 & 2 & 13,3 \\
Nunca & 2 & - & - & - & 2 & 13,3 \\
Não sei & 3 & 20,0 & 5 & 33,3 & 8 & 53,3 \\
\hline TOTAL & 6 & 40,0 & 9 & 60,0 & 15 & 100,0 \\
\hline
\end{tabular}

Fonte: Dados da Pesquisa.

A motivação de considerar o relacionamento e integração com os fornecedores é apontada na literatura (CHING, 1999; BALLOU, 2007; CHRISTOPHER, 1997) pelos benefícios de proporcionar: parceiros mais fortes; foco comum na qualidade; confiabilidade de entregas mais estáveis e repetitivas; redução dos níveis de estoque; menos burocracia; dependência mútua e congruência de objetivos; e custos da cadeia logística reduzidos.

É interessante considerar que para apenas $13,3 \%$ houve redução dos fornecedores, e, embora seja um número pequeno, confirma a literatura. Já 26,6\% das respostas obtidas manifestam que na prática há contradição com o disposto na literatura e o fato de 53,3\% não terem conhecimento sobre a redução de fornecedores é um dado que contradiz a literatura que preconiza relacionamentos de parceria. Por outro lado, mesmo não ocorrendo a referida redução conforme o aporte teórico há sensibilização e iniciativas de aproximação para parcerias e de certificação dos fornecedores. 
Para E6 "houve redução com a implantação do e-procument [ferramenta eletrônica de cotação de preços, de compra e venda corporativos realizados pela internet]", ratificado por E10: "acredito que esteja reduzindo". Para E12 "não ocorreu redução" e E15 explica que "houve redução de produtos, mas acaba tendo mais fornecedores cadastrados no sistema atualmente".

Evidenciou-se durante as visitas, principalmente por parte dos hospitais públicos, forte preocupação quanto à aproximação e sensibilização dos fornecedores às necessidades do hospital, com iniciativas de reuniões periódicas dos fornecedores atuais e potenciais com as equipes de profissionais da instituição, de acordo com os produtos e materiais de sua área de atuação.

Nas organizações públicas, uma das dificuldades apontadas foi a de que apesar das iniciativas de integração com os fornecedores, o primeiro critério de aquisição é preço, determinado pela legislação vigente. Percebeu-se, em um dos hospitais públicos pesquisados, forte empenho no desenvolvimento de instrumental administrativo que conta com a descrição detalhada de cada item e do parecer técnico como estratégia de garantia de qualidade dos insumos a serem adquiridos.

Durante as visitas, um dos acompanhantes informou que até o ano 2000 as compras e o pedido de mat/méd ficavam a cargo do almoxarifado; isso evoluiu e hoje é possível estreitar o relacionamento com os fornecedores.

Embora seja perceptível a preocupação e esforços dos executivos na aproximação e sensibilização dos fornecedores, caminhando em direção ao preconizado na literatura, é exigido ainda um efetivo processo de desenvolvimento dos fornecedores. É necessário pensar em um nível de coordenação que extrapole os limites das organizações para cumprir a integração de funções internas dentro dos hospitais em toda a cadeia. 
4.4.3.2 E-procurement - ferramenta eletrônica de cotação de preços, de compra e venda corporativas realizadas pela internet.

A tecnologia está trazendo novo significado à estratégia de suprimentos. Cada vez mais enfoques sofisticados, tais como mercados B2B (comércio eletrônico entre empresas) on-line, consórcios de compra, leilões e trocas vêm permitindo que as organizações descubram e explorem oportunidades de mercado de suprimento.

Analisando a Tabela 13 verifica-se que 46,7\% dos executivos responderam que as compras eletrônicas representam mais de $80 \%$ das aquisições nas organizações hospitalares estudadas, representando forte aderência às tecnologias relacionadas ao comércio eletrônico B2B (comércio eletrônico entre as empresas). Isso significa que estão optando por transações comerciais padronizadas, uma vez que compradores e vendedores estão ligados pela rede eletrônica. Esse processamento de transações é altamente informatizado, os relacionamentos com os fornecedores são estabelecidos eletronicamente e os níveis de serviço tendem a ser melhorados (MOURA et al., 2003; CHING, 1999).

A somatória de $66,7 \%$ correspondente às respostas "sempre" $\mathrm{e}$ "às vezes" demonstra evolução da logística nas organizações de saúde em experimentar novas tecnologias, entre elas, o e-procurement (ferramenta eletrônica de cotação de preços, de compra e venda corporativas realizadas pela internet) que vem sendo apontado como uma maneira de reduzir custos desnecessários nas operações de aquisição, combinando a melhor forma de comprar com as tecnologias da internet (GOMES e RIBEIRO, 2004).

Dos entrevistados, 20\% responderam que "às vezes" acontece. Para 6,7\% que representam o setor público "quase nunca" acontece; $26,6 \%$ dos participantes não têm conhecimento da evolução das aquisições do hospital por meios eletrônicos e representam o setor privado, o que leva a deduzir que as informações referentes a 
compras são escassamente compartilhadas entre os executivos que atuam direta ou indiretamente na área de logística.

Tabela 13 - Compras eletrônicas representam mais de $80 \%$ das aquisições mensais.

\begin{tabular}{l|c|c|c|c|c|c}
\hline \multirow{2}{*}{} & \multicolumn{5}{|c|}{ HOSPITAIS } \\
\cline { 2 - 7 } & \multicolumn{2}{|c|}{ PÚBLICO } & \multicolumn{2}{c}{ PRIVADO } & \multicolumn{2}{c}{ TOTAL } \\
\cline { 2 - 7 } & $\mathrm{N}$ & $\%$ & $\mathrm{~N}$ & $\%$ & $\mathrm{~N}$ & $\%$ \\
\hline Sempre & 4 & 26,7 & 3 & 20,0 & 7 & 46,7 \\
Às vezes & 1 & 6,7 & 2 & 13,3 & 3 & 20,0 \\
Quase nunca & 1 & 6,7 & - & - & 1 & 6,7 \\
Nunca & - & - & - & - & - & - \\
Não sei & - & - & 4 & - & 4 & 26,6 \\
\hline TOTAL & 6 & 40,0 & 9 & 60,0 & 15 & 100,0 \\
\hline
\end{tabular}

Fonte: Dados da Pesquisa.

E6 informa que $100 \%$ das aquisições são por meio do B2B e complementa sobre os principais meios utilizados: "IMPAT, Bionexo, Mercado Eletrônico e Portais Eletrônico dos Fornecedores", citando os portais: www.bionexo.com.br; www.webb.com.br; www.mercadoeletronico.com.br. Observa, também, que "alguns fornecedores não colocam preços em sites que não sejam próprios, citando, por exemplo, a empresa J\&J”.

Um dos hospitais pesquisados menciona que vem "utilizando há pouco tempo ferramentas de compras pela internet, não tendo atingido, ainda, o índice mencionado" de mais de $80 \%$ e que "esperamos no decorrer do próximo ano, atingir este indice para medicamentos". (E14)

Prevaleceu nos hospitais públicos, a utilização das modalidades " $B E C$ (Bolsa Eletrônica de Compras); "Pregão eletrônico e presencial, e leilão". 


\subsubsection{Avaliação dos Fornecedores}

A avaliação de fontes potenciais de suprimentos é um processo contínuo das áreas de compras das diversas organizações do mundo empresarial. Com o advento do comércio eletrônico, de conceitos de relacionamento colaborativo, ou de parceria com a base fornecedora, faz-se necessária a avaliação e, até mesmo, o desenvolvimento de fornecedores.

Tabela 14 - Os fornecedores são avaliados sistematicamente.

\begin{tabular}{l|c|c|c|c|c|c}
\hline \multirow{2}{*}{} & \multicolumn{6}{|c|}{ HOSPITAIS } \\
\cline { 2 - 7 } & \multicolumn{2}{|c|}{ PÚBLICO } & \multicolumn{2}{c}{ PRIVADO } & \multicolumn{2}{c}{ TOTAL } \\
\cline { 2 - 7 } & $\mathrm{N}$ & $\%$ & $\mathrm{~N}$ & $\%$ & $\mathrm{~N}$ & $\%$ \\
\hline Sempre & 4 & 26,7 & 6 & 40,0 & 10 & 66,6 \\
Às vezes & 1 & 6,7 & 2 & 13,3 & 3 & 20,0 \\
Quase nunca & 1 & 6,7 & 1 & 6,7 & 2 & 13,3 \\
Nunca & - & - & - & - & - & - \\
Não sei & - & - & - & - & - & - \\
\hline TOTAL & 6 & 40,0 & 9 & 60,0 & 15 & 100,0 \\
\hline
\end{tabular}

Fonte: Dados da Pesquisa.

Questionados se os fornecedores dos hospitais em estudo são avaliados sistematicamente, $66,7 \%$ dos executivos entrevistados manifestam que isso "sempre" acontece, o que demonstra preocupação por parte das organizações no desenvolvimento de fornecedores. Para $20 \%$ isso ocorre "às vezes" e $13,3 \%$ não souberam responder, o que sugere, como resultado de pesquisa, que se não sabem o que acontece e ocupam posição de mando no organograma, relacionam-se com a área de logística e desconhecem se os fornecedores são avaliados e em que grau. 
E5, E6 e E12 remetem à avaliação do Grupo de Avaliação de Fornecedores (GAFO); um dos entrevistados afirma que também "realizamos visitas técnicas com a equipe de farmacêuticos do hospital". E15 informa que "a avaliação conta com a participação de equipe multidisciplinar". Tal posicionamento favorece ao apontado na literatura quanto à avaliação e integração com os fornecedores, ao verificarem as capacidades dos fornecedores quanto ao estado das instalações fabris; capacidade tecnológica; nível de qualidade; e prazos de fornecimento, entre outros (CHING, 1999; BALLOU, 2007).

As organizações em estudo, reservadas as características e a legislação específica para instituições privadas e públicas, demonstraram evolução da tradicional trajetória para fazer chegar suprimentos médico-hospitalares da fábrica até ao paciente. Aos que já trabalharam nessa área com certeza já amargaram com entraves como morosidade e erros durante os processos de pedidos e de compras, favorecidos por processos manuais, sem contar os atrasos e elevados custos.

A realidade das organizações estudadas demonstrou avanços na incorporação da logística estratégica de suprimentos; enfrenta desafios no planejamento, controle e execução ao tratar uma demanda muitas vezes incerta e têm apresentado tentativas de estreitar o relacionamento com os fornecedores.

Embora segundo o resultado das entrevistas, não esteja havendo redução no número de fornecedores, os hospitais utilizam-se do e-commerce (comércio eletrônico), que permite a transmitir eletronicamente documentos e enviar e receber pagamentos por meio eletrônico. Isso favorece a confiança nas relações bilaterais e a velocidade na transação, apesar de não demonstrar compartilhamento das informações referentes aos processos de compras com os executivos que atuam na cadeia logística interna do hospital (CHRISTOPHER, 1997; MOURA, 2003; GOMES e RIBEIRO, 2004). 


\subsubsection{Interface dos profissionais de saúde na demanda de suprimentos}

Foi questionado a um representante de cada hospital estudado em relação a essa interface que se apresenta resumidamente no Quadro 4. Ao analisar o quadro, observa-se que no setor privado os médicos participam da seleção de produtos e da decisão sobre a compra e que a incorporação dos conceitos de logística/SC no ambiente hospitalar demonstra tendência em rever a participação do profissional na cadeia produtiva hospitalar, para parceiro.

Há de se considerar, também, a influência dos fornecedores de medicamentos e produtos médico-hospitalares nos profissionais tomadores de decisão, incluindo aqueles que interferem por meio do receituário e de seu conhecimento e opinião, como iniciantes da cadeia de demanda por produtos aos seus pacientes. Em relação ao setor público, os processos licitatórios são acompanhados por profissionais técnicos das diversas áreas.

Os entrevistados manifestaram a forte participação dos profissionais médicos na escolha dos materiais e medicamentos; há de se considerar que, diferentemente da indústria, os procedimentos cirúrgicos podem ser considerados como modelos artesanais de produção e os médicos buscam obter o melhor resultado com os insumos disponíveis. De acordo com características de cada paciente; fazem uso de seus conhecimentos técnicos e também de suas experiências anteriores e intuição. Esse modelo artesanal é marcado pela autonomia do médico.

BALLARD (2005) manifesta que é importante propor a atenção dos médicos para questões financeiras baseadas em informações confiáveis que possibilitem ao profissional conhecer os valores e impactos financeiros de suas opções. Assim, podem colaborar na avaliação de quais produtos serão padronizados e utilizados, conhecerem a sua representação na cadeia de suprimentos e sua inserção no sistema de saúde. 
Quadro 5 - Percepções sobre a interface dos profissionais em relação a suprimentos segundo a natureza da organização

\begin{tabular}{|c|c|}
\hline PÚBLICO & PRIVADO \\
\hline $\begin{array}{l}\text { "os profissionais de cada área acompanham } \\
\text { ativamente os processos licitatórios". }\end{array}$ & $\begin{array}{l}\text { “o médico influencia muito no produto } \\
\text { adquirido e muitas vezes numa postura mais de } \\
\text { cliente do que de parceiro”. (...) o médico não } \\
\text { necessariamente é funcionário do hospital ele } \\
\text { também é cliente quando é ele que origina o } \\
\text { tratamento na instituição". } \\
\text { "o hospital já foi mero tirador de pedidos de } \\
\text { compras, principalmente em oPME, o médico é } \\
\text { um motivador de compras e tem-se a } \\
\text { necessidade de readequação desse profissional } \\
\text { para parceiro". } \\
\text { “buscamos utilizar os medicamentos e materiais } \\
\text { padronizados e quando não temos o } \\
\text { medicamento receitado entramos em contato } \\
\text { com o médico para o uso do similar”. (...) “o } \\
\text { que acontece muitas vezes é que o paciente exige } \\
\text { determinado medicamento". }\end{array}$ \\
\hline
\end{tabular}

Fonte: Dados da Pesquisa.

A fala de um dos hospitais privados "buscamos utilizar os medicamentos $e$ materiais padronizados e quando não temos o medicamento receitado entramos em contato com o médico para o uso do similar", expressa cooperação entre as áreas funcionais do hospital para a implementação da padronização dos itens e otimização dos recursos destinados a insumos. Isso se dá pela aproximação dentro da equipe multidisciplinar que atua direta e indiretamente no atendimento ao paciente e proximidade com o preconizado na literatura (BOWERSOX, CLOSS, 2001; CHING, 2001; BALLOU, 2007) a respeito da integração de um processo logístico que requer que os executivos transponham a estrutura organizacional e adotem a coordenação interfuncional. A evocação citada também demonstra o comportamento do cliente atual mais 
informado e esclarecido "o que acontece muitas vezes é que o paciente exige determinado medicamento".

\subsection{POSICIONAMENTO LOGÍSTICO E POLÍTICA DE ATENDIMENTO AO PACIENTE}

Quanto ao posicionamento logístico no atendimento internado e ambulatorial, os serviços de saúde ao longo do tempo vivenciaram a política de antecipação de demanda refletida em grandes estoques em almoxarifados centrais, além de muitos pontos de armazenagem posicionados nas diversas clínicas, setores e salas de atendimento. Nos hospitais estudados percebeu-se a adoção dos caminhos de antecipação de demanda e de resposta rápida.

A lógica da Resposta Rápida pauta-se em que a demanda seja captada em tempo tão próximo quanto possível da realidade e do cliente final, envolvendo a substituição de estoques por informação (CHRISTOPHER, 1997, p. 174).

\subsubsection{Canal de Distribuição e Distribuição Física}

O Quadro 5 apresenta algumas características de distribuição física interna de materiais e medicamentos, adotadas nos hospitais estudados. O processo de distribuição interna de materiais refere-se à movimentação entre os estoques e os pontos de produção, ou prestação de serviço. Algumas técnicas determinam as melhores formas de distribuição, como roteamento da movimentação e racionalização de recursos, entregas mais frequentes e menores volumes, entre outros. (BOWERSOX, 2001; CHING, 2001; WANKE, 2003). 
Quadro 6 - Distribuição Interna

\begin{tabular}{|c|c|c|c|c|c|}
\hline & $\mathrm{HA}$ & $\mathrm{HB}$ & $\mathrm{HC}$ & $\mathrm{HD}$ & $\mathrm{HE}$ \\
\hline $\begin{array}{l}\text { Forma de } \\
\text { Distribuição } \\
\text { interna }\end{array}$ & $\begin{array}{l}\text { Planejada e } \\
\text { programada em } 4 \\
\text { entregas por dia }\end{array}$ & $\begin{array}{l}\text { Aleatória } \\
\text { Em forma de } \\
\text { reposição do } \\
\text { estoque mínimo } \\
\text { de cada clínica }\end{array}$ & $\begin{array}{l}\text { Programada e } \\
\text { acordada com } \\
\text { cada centro de } \\
\text { custo }\end{array}$ & $\begin{array}{l}\text { Programada } \\
\text { conforme } \\
\text { cronograma } \\
\text { Os setores fazem } \\
\text { pedidos duas } \\
\text { vezes por semana. }\end{array}$ & $\begin{array}{l}\text { Programada } \\
\text { de hora em hora } \\
\text { durante } \\
\text { 24horas/dia }\end{array}$ \\
\hline Tipo de dose & $\begin{array}{l}\text { Unitária - } \\
\text { sistema de } \\
\text { dispensação } \\
\text { prescrita para o } \\
\text { paciente na dose e } \\
\text { prazo corretos, } \\
\text { com a vantagem de } \\
\text { minimizar erros. }\end{array}$ & $\begin{array}{l}\text { Unitária - sistema } \\
\text { de dispensação } \\
\text { prescrita para o } \\
\text { paciente - } \\
\text { lançamento e } \\
\text { consumo por } \\
\text { paciente. }\end{array}$ & $\begin{array}{l}\text { Unitária e por } \\
\text { Paciente }\end{array}$ & $\begin{array}{l}\text { Mista - unitária e } \\
\text { coletiva }\end{array}$ & $\begin{array}{l}\text { Individualizada e } \\
\text { indireta }\end{array}$ \\
\hline Tipo de entrega & Consolidada & & & Consolidada & Consolidada \\
\hline $\begin{array}{l}\text { Freqüência de } \\
\text { entrega }\end{array}$ & $\begin{array}{l}\text { Em horários } \\
\text { programados por } \\
\text { meio de carrinhos } \\
\text { simples e } \\
\text { abastecimento das } \\
\text { pyxis. }\end{array}$ & $\begin{array}{l}\text { No periodo da } \\
\text { tarde na maioria } \\
\text { das vezes, devido } \\
\text { ao menor fluxo de } \\
\text { pacientes - carros } \\
\text { modernos de } \\
\text { entrega. }\end{array}$ & $\begin{array}{l}\text { Cronograma } \\
\text { diário de } \\
\text { dispensação, o } \\
\text { pedido é emitido } \\
\text { e impresso por } \\
\text { ordem de } \\
\text { endereçamento- } \\
\text { carrinho moderno } \\
\text { e entrega por } \\
\text { centro de custo }\end{array}$ & $\begin{array}{l}\text { Entrega realizada } \\
\text { diariamente de } \\
\text { acordo com } \\
\text { escala em carros } \\
\text { grandes e simples } \\
\text { e cobertos }\end{array}$ & De hora em hora \\
\hline $\begin{array}{l}\text { Rota de } \\
\text { carregamento e } \\
\text { entrega. }\end{array}$ & $\begin{array}{l}\text { Acoplada e } \\
\text { padronizada. }\end{array}$ & $\begin{array}{l}\text { Acoplada e semi- } \\
\text { padronizada }\end{array}$ & $\begin{array}{l}\text { Acoplada e } \\
\text { padronizada }\end{array}$ & $\begin{array}{l}\text { Não acoplada e } \\
\text { não padronizada - } \\
\text { de acordo com a } \\
\text { experiência dos } \\
\text { funcionários - } \\
\text { que alegam } \\
\text { priorizar a UTI }\end{array}$ & Não acoplada \\
\hline Armazenagem & $\begin{array}{l}\text { Descentralizada } \\
\text { Estrategicamente }\end{array}$ & Descentralizada & $\begin{array}{l}\text { Descentralizada } \\
\text { Estrategicamente }\end{array}$ & Descentralizada & Centralizada \\
\hline $\begin{array}{l}\text { Tempo médio dos } \\
\text { mat/méd em } \\
\text { processo }\end{array}$ & 3 dias & $\begin{array}{l}\text { Abastece uma ou } \\
\text { duas vezes por } \\
\text { semana }\end{array}$ & 3 dias no máximo & Não controla & $\begin{array}{l}\text { Abastecimento } \\
\text { contínuo }\end{array}$ \\
\hline $\begin{array}{l}\text { Mat } / \text { méd em } \\
\text { processo nas } \\
\text { clinicas }\end{array}$ & $\begin{array}{l}\text { Administrados } \\
\text { pela Farmácia }\end{array}$ & $\begin{array}{l}\text { Estoque minimo - } \\
\text { administrado pela } \\
\text { Enfermagem }\end{array}$ & $\begin{array}{l}\text { Estoque minimo } \\
\text { em administração } \\
\text { compartilhada } \\
\text { com a } \\
\text { Enfermagem }\end{array}$ & $\begin{array}{l}\text { Cada unidade tem } \\
\text { seu estoque. O } \\
\text { almoxarifado } \\
\text { lança como saida } \\
\text { os materiais } \\
\text { enviado às } \\
\text { clínicas }\end{array}$ & $\begin{array}{l}\text { Administrado } \\
\text { pela Enfermagem } \\
\text { com controle da } \\
\text { Farmácia }\end{array}$ \\
\hline $\begin{array}{l}\text { Reposição às } \\
\text { clinicas }\end{array}$ & $\begin{array}{l}\text { Automática de } \\
\text { acordo com } \\
\text { sistema }\end{array}$ & $\begin{array}{l}\text { Automática de } \\
\text { acordo com } \\
\text { relatório impresso }\end{array}$ & $\begin{array}{l}\text { Automática de } \\
\text { acordo com } \\
\text { mínimo e máximo }\end{array}$ & $\begin{array}{l}\text { Mediante pedido } \\
\text { de acordo com } \\
\text { escala }\end{array}$ & $\begin{array}{l}\text { Por pedido via } \\
\text { sistema }\end{array}$ \\
\hline
\end{tabular}

Fonte: Dados da Pesquisa. 
O sistema de distribuição interna também influencia o processo, pois quanto mais unidades de estoque existir, maior será a dificuldade no seu gerenciamento (BARBIERI, 2006).

\subsection{INTEGRAÇÃO}

Contemporaneamente, a logística é estudada de forma integrada. O serviço logístico ideal e apregoado na literatura (BALLOU, 2007; BOWERSOX, CLOSS, 2001; CHING, 1999; CHRISTOPHER, 1997) é aquele realizado de forma integrada, gerenciado e controlado pela própria organização ou terceirizado. As informações obtidas nas entrevistas realizadas confirmam parcialmente essa integração no hospital.

Tabela 15 - Integração plena no planejamento e na execução das atividades logísticas no hospital

\begin{tabular}{l|c|c|c|c|c|c}
\hline \multirow{2}{*}{} & \multicolumn{2}{|c|}{ HOSPITAIS } \\
\cline { 2 - 7 } & \multicolumn{2}{|c|}{ PÚBLICO } & \multicolumn{2}{c}{ PRIVADO } & \multicolumn{2}{c}{ TOTAL } \\
\cline { 2 - 7 } & $\mathrm{N}$ & $\%$ & $\mathrm{~N}$ & $\%$ & $\mathrm{~N}$ & $\%$ \\
\hline Sempre & 3 & 20,0 & 6 & 40,0 & 9 & 60,0 \\
Às vezes & 1 & 6,7 & 2 & 13,3 & 3 & 20,0 \\
Quase nunca & 2 & 13,3 & 1 & 6.7 & 3 & 20,0 \\
Nunca & - & - & - & - & - & - \\
Não sei & - & - & - & - & - & - \\
\hline TOTAL & 6 & 40,0 & 9 & 60,0 & 15 & 100,0 \\
\hline
\end{tabular}

Fonte: Dados da Pesquisa. 
Dos hospitais estudados, quatro deles optaram pelo gerenciamento e próprio da logística e um deles optou pela estratégia de terceirização da logística interna.

A tabela 15 demonstra que $60 \%$ dos executivos consideram que há integração plena no planejamento e execução das atividades de logística na organização. Para 20\% isso ocorre "às vezes" e "quase nunca" acontece representa a resposta de $20 \%$ dos participantes, composto por $13,3 \%$ do setor púbico e $6,7 \%$ do setor privado. Nessa questão, os informantes citaram que "ainda ocorrem falhas (atraso) na entrega de insumos nas unidades em relação ao prazo estipulado, melhorou, mas ainda ocorre".

E8 entende que existe integração entre planejamento e execução "com ressalvas, frente ao desafio da logística que é colocar o produto certo, na hora certa, na quantidade certa, na qualidade certa. Conflitos saudáveis existem”. E10 aborda o fato de que na organização "existe documento institucional "Logística $e$ distribuição", com rotinas de cada área, formalizada". Na percepção de E15 "existe ainda um gap, muitas vezes decorrente do sistema e das necessidades de se atingir certas metas orçamentárias e as atitudes são tomadas sem planejar com a área”.

A tabela 16 evidencia que para $1 / 3$ dos respondentes os materiais e medicamentos não estão integrados e não estão sob o controle da área de suprimentos; $13,3 \%$ deles afirmam que "às vezes" acontece, a resposta afirmativa "sempre acontece" é de $53,3 \%$, compostos por $40,0 \%$ do setor privado e $13,3 \%$ do público.

As respostas "nunca" e "quase nunca" acontece representam 33,4\% . A representação no setor público de $26,7 \%$ do universo de $40 \%$ é um dado significativo e deduz-se como um dos reflexos da estrutura organizacional do setor público e das alocações de recursos em funções, divergindo do preconizado como foco da gestão integrada (BOWERSOX, CLOSS e COOPER, 2007; BALLOU, 2007) em menor 
custo total do processo, o que não significa menor custo para cada função incluída no processo.

Tabela 16 - Materiais e Medicamentos de cada clínica estão integrados ao planejamento e controle da gestão de suprimentos

\begin{tabular}{l|c|c|c|c|c|c}
\hline \multirow{2}{*}{} & \multicolumn{5}{|c|}{ HOSPITAIS } \\
\cline { 2 - 7 } & \multicolumn{2}{|c|}{ PÚBLICO } & \multicolumn{2}{c}{ PRIVADO } & \multicolumn{2}{c}{ TOTAL } \\
\cline { 2 - 7 } & $\mathrm{N}$ & $\%$ & $\mathrm{~N}$ & $\%$ & $\mathrm{~N}$ & $\%$ \\
\hline Sempre & 2 & 13,3 & 6 & 40,0 & 8 & 53,3 \\
Às vezes & - & - & 2 & 13,3 & 2 & 13,3 \\
Quase nunca & 1 & 6,7 & - & - & 1 & 6,7 \\
Nunca & 3 & 20,0 & 1 & 6,7 & 4 & 26,7 \\
Não sei & - & - & - & - & - & - \\
\hline TOTAL & 6 & 40,0 & 9 & 60,0 & 15 & 100,0 \\
\hline
\end{tabular}

Fonte: Dados da Pesquisa.

E5 afirma que o controle é compartilhado com a equipe de enfermagem/administrativa de cada clínica, "a orientação técnica e os inventários são realizados pela equipe de suprimentos e o controle/baixa, código de barras e contagens diárias são realizados pela equipe local subordinada à enfermagem”.

Para E10, no planejamento desconta-se o estoque das pyxis (gabinetes automatizados utilizados na distribuição de medicamentos em substituição de Farmácias Satélites e "Farmacinhas" do posto de Enfermagem). "As pyxis substituíram um farmacêutico que existia anteriormente em cada andar". E12 afirma que na organização em que trabalha a área de suprimentos não atua nos estoques em movimento e utiliza a terminologia de almoxarifado, "o almoxarifado desconhece as quantidades" de materiais e medicamentos após a dispensação para as clínicas. E15 coloca que "em relação aos SADT's não estão totalmente integrados, pois neste momento estamos em processo de integração da gestão dos mesmos à gestão do Hospital”. 
A análise dessas intervenções explicita que os hospitais estudados estão em diferentes estágios na implementação da estratégia logística, enquanto um apresenta altos investimentos em tecnologia e automação, com sistema integrado do fluxo de materiais e informação e controle da área de suprimentos em todo o processo, em outro hospital, após a dispensação para os setores e clínicas não há controle ou conhecimento por parte da área de suprimentos de materiais e medicamentos em processo. Percebe-se um desnivelamento de investimentos em tecnologias de informação no processo de implementação da logística nesses serviços de saúde (BALLOU, 2007; BOWERSOX, CLOSS, 2001; NOVAES, 2007).

Quanto à integração dos fluxos de materiais e financeiro, 60\% dos executivos afirmam que esses fluxos estão integrados; para $20 \%$ às vezes. Nota-se que a soma das respostas quase nunca e nunca acontece equivale a $20 \%$ e representa somente o setor público.

\begin{tabular}{|c|c|c|c|c|c|c|}
\hline & \multicolumn{6}{|c|}{ HOSPITAIS } \\
\hline & \multicolumn{2}{|c|}{ PÚBLICO } & \multicolumn{2}{|c|}{ PRIVADO } & \multicolumn{2}{|c|}{ TOTAL } \\
\hline & $\mathrm{N}$ & $\%$ & $\mathrm{~N}$ & $\%$ & $\mathrm{~N}$ & $\%$ \\
\hline Sempre & 2 & 13,3 & 7 & 46,7 & 9 & 60,0 \\
\hline Às vezes & 1 & 6,7 & 2 & 13,3 & 3 & 20,0 \\
\hline Quase nunca & 2 & 13,3 & - & - & 2 & 13,3 \\
\hline Nunca & 1 & 6,7 & - & - & 1 & 6,7 \\
\hline Não sei & - & - & - & - & - & - \\
\hline TOTAL & 6 & 40,0 & 9 & 60,0 & 15 & 100,0 \\
\hline
\end{tabular}

Fonte: Dados da Pesquisa.

No setor público, metade dos participantes afirma que essa integração "quase nunca" ou "nunca" acontece; no setor privado, o universo de $60 \%$ "sempre" acontece representa $46,7 \%$ das repostas. Deduz-se que o setor privado vem 
priorizando investimentos em tecnologia da informação que favoreçam a integração dos fluxos.

No campo complementar, E4 traz que "é integrado, mas gera estorno e devolução, pois não cai na conta pela "checagem” e sim pela dispensação". Em outras palavras, é realizado o lançamento por suprimentos e depois estornado na área de enfermagem o que não foi utilizado. E6 afirma que "o fluxo de caixa é integrado" e E15 complementa que "são sistemas diferentes".

Nas organizações públicas o discurso e conflitos em investir em tecnologia em detrimento da assistência é passivo de discussão, a necessidade financeira acaba levando para tomada de decisões limitadas ao não considerar que os investimentos em tecnologia permitem o fortalecimento da organização e o sua própria manutenção no mercado, seja público ou privado. Outra questão a ser considerada são os custos ocultos da logística que, dentre eles, os valores pagos para a manutenção dos estoques, a obsolescência e deteriorização dos estoques, o custo da falta de insumos, que acarreta em outros custos além do comprometimento da imagem da organização, conflitos entre os membros da cadeia produtiva, insatisfação do paciente estendida aos familiares.

Um dos fatores que afeta diretamente a gestão de suprimentos é o fluxo de informações. Quanto mais precisas e disponíveis, maiores as possibilidades de otimização dos estoques (BOWERSOX, CLOSS, COOPER, 2007; BALLOU, 2007; MOURA et al., 2003).

Os entrevistados apontam que inovações tecnológicas na área de logística em TI (Tecnologia da Informação) têm permitido agilidade nos processos e proporcionado redução de estoques e de custos, representando $60 \%$ das respostas. Para 13,3\% isso "às vezes" acontece e "quase nunca" para 13,3\% (Tabela 18).

Uma questão que chamou atenção foi que metade dos participantes do setor público alegou "quase nunca", "nunca" e "não sei", emergindo prováveis 
dificuldades ou atrasos da área pública em acompanhar tais investimentos nessa área, distanciando-se da implementação da estratégia logística e apresentando facetas do modelo tradicional da logística no ambiente hospitalar.

\begin{tabular}{|c|c|c|c|c|c|c|}
\hline & \multicolumn{6}{|c|}{ HOSPITAIS } \\
\hline & \multicolumn{2}{|c|}{ PÚBLICO } & \multicolumn{2}{|c|}{ PRIVADO } & \multicolumn{2}{|c|}{ TOTAL } \\
\hline & $\mathrm{N}$ & $\%$ & $\mathrm{~N}$ & $\%$ & $\mathrm{~N}$ & $\%$ \\
\hline Sempre & 3 & 20,0 & 6 & 40,0 & 9 & 60,0 \\
\hline Às vezes & - & - & 2 & 13,3 & 2 & 13,3 \\
\hline Quase nunca & 1 & 6,7 & 1 & 6,7 & 2 & 13,3 \\
\hline Nunca & 1 & 6,7 & - & - & 1 & 6,7 \\
\hline Não sei & 1 & 6,7 & - & - & 1 & 6,7 \\
\hline TOTAL & 6 & 40,0 & 9 & 60,0 & 15 & 100,0 \\
\hline
\end{tabular}

Fonte: Dados da Pesquisa.

Alguns dos executivos justificam, ou acrescentam em relação às suas opções, que "nesse sentido a área de suprimentos é muito dependente da iniciativa dos profissionais, deveria ser mais proativa na busca de soluções no mercado"(E15). Nas palavras de E13 “o hospital está iniciando, o processo de informação nos ambulatórios teve resultado importante, com redução de estoques $e$ redução de custos e agilização dos processos. E6 manifesta que estão ocorrendo investimentos atuais na "implantação de PDA's nas Farmácias e Sala Limpa de preparo de medicamentos".

A logística integrada pressupõe a construção de uma integração intra e inter- organizacional que deve resultar em aprendizado e eficiência coletivos. Quanto à integração interna, a literatura aponta como principais barreiras a estrutura organizacional, os sistemas de mensuração, estoques, tecnologia de informação e 
capacidade de transferência de conhecimento (BOWERSOX, CLOSS, 2001; NOVAES, 2007; CHING, 2001).

\subsection{FATOR HUMANO}

Os paradigmas contemporâneos de gestão organizacional apontam para a primazia das pessoas na busca da excelência para a produção de bens e serviços e para viabilizar a transformação institucional.

Os participantes foram questionados para responder, "sim" ou "não", se a organização contratou profissionais da área de logística nos últimos três anos; 73,3\% responderam positivamente e observou-se que as organizações, principalmente as do setor privado, têm buscado profissionais no mercado da indústria. Segundo E8, "recentemente foi contratado novo gerente em um dos cargos de logística que atuava no mercado da indústria automobilística".

Durante as visitas, observou-se que as organizações estudadas vêm contratando profissionais do mercado industrial para atuar na área de implementação de projeto na área de logística, incluindo um dos responsáveis pela área de suprimentos em um dos hospitais pesquisados, que era recém contratado e estava se interando do ambiente hospitalar.

Para 26,7\% dos entrevistados, o hospital não tem contratado profissionais da área de logística, por motivo de terceirização dos serviços dessa área. Já para E12, "o quadro de recursos humanos da organização é de 1978 e não contempla cargos com a nomenclatura e atividades de logística nos conceitos atuais".

Considerando as mudanças no atual mundo organizacional dispostas até o momento neste estudo e a evolução tecnológica que elimina muitas posições e cria outras, essas modificações se refletem no mercado de trabalho e os cargos e as 
funções precisam se adaptar a nova realidade (MOURA, et al., 2003; BERTAGLIA, 2005), nas organizações hospitalares estudadas, o setor privado demonstrou flexibilidade em adequar cargos e posições. O setor público demonstrou esbarrar em morosidade da legislação da estrutura organizacional em acompanhar a velocidade das mudanças, apesar do conhecimento e empenho dos executivos.

A análise da Tabela 19 destaca que 73,3\% dos entrevistados mostram a preocupação das organizações estudadas em promover o aprendizado e troca de experiência entre os colaboradores, o que fortalece os dados apresentados no Quadro1 quanto à preocupação com o quadro de profissionais qualificados. E8 complementa que "a politica de recursos humanos do hospital exige que todos os profissionais tenham educação continuada", o que favorece para expandir o escopo de conhecimento, diminuição dos riscos de obsolescência pessoal e de que a mudança organizacional é inevitável para que a organização permaneça no mercado, seja público ou privado, além de serem mais valorizados no mercado de trabalho. (BOWERSOX, CLOSS, 2001).

Tabela 19 - A organização promove o aprendizado e troca de experiência entre seus colaboradores.

\begin{tabular}{l|c|c|c|c|c|c}
\hline \multirow{2}{*}{} & \multicolumn{5}{|c|}{ HOSPITAIS } \\
\cline { 2 - 7 } & \multicolumn{2}{|c|}{ PÚBLICO } & \multicolumn{2}{c|}{ PRIVADO } & \multicolumn{2}{c}{ TOTAL } \\
\cline { 2 - 7 } & $\mathrm{N}$ & $\%$ & $\mathrm{~N}$ & $\%$ & $\mathrm{~N}$ & $\%$ \\
\hline Sempre & 5 & 33,3 & 6 & 40,0 & 11 & 73,3 \\
Às vezes & 1 & 6,7 & 3 & 20,0 & 4 & 26,7 \\
Quase nunca & - & - & - & - & - & - \\
Nunca & - & - & - & - & - & - \\
Não sei & - & - & - & & - & - \\
\hline TOTAL & 6 & 40,0 & 9 & 60,0 & 15 & 100,0 \\
\hline
\end{tabular}

Fonte: Dados da Pesquisa. 
Prevaleceu, em 93,3\% das respostas, que o ambiente proporcionado pelas organizações estudadas favorece o autodesenvolvimento dos colaboradores. E3 afirma que "constantemente temos oportunidade de crescimento na Instituição". Nas palavras de E8 "quatro funcionários estavam fazendo um curso de planejamento de logística, e o hospital pagou em torno de $50 \%$ do curso. Na pós-graduação e na graduação, o hospital participa com um certo percentual do financiamento. Há preocupação por parte da instituição para as pessoas evoluirem e se desenvolverem". E6 cita que "são realizadas seis oficinas/ano".

Tabela 20 - Os profissionais encontram ambiente favorável para o autodesenvolvimento.

\begin{tabular}{l|c|c|c|c|c|c}
\hline \multirow{2}{*}{} & \multicolumn{6}{|c|}{ HOSPITAIS } \\
\cline { 2 - 7 } & \multicolumn{2}{|c|}{ PÚBLICO } & \multicolumn{2}{c}{ PRIVADO } & \multicolumn{2}{c}{ TOTAL } \\
\cline { 2 - 7 } & $\mathrm{N}$ & $\%$ & $\mathrm{~N}$ & $\%$ & $\mathrm{~N}$ & $\%$ \\
\hline Sempre & 5 & 33,3 & 9 & 60,0 & 14 & 93,3 \\
Às vezes & 1 & 6,7 & - & - & 1 & 6,7 \\
Quase nunca & - & - & - & - & - & - \\
Nunca & - & - & - & - & - & - \\
Não sei & - & - & - & - & - & - \\
\hline TOTAL & 6 & 40,0 & 9 & 60,0 & 15 & 100,0 \\
\hline
\end{tabular}

Fonte: Dados da Pesquisa.

As organizações públicas e privadas que participaram desta pesquisa, cada uma de acordo com suas características, demonstraram propiciar ambiente favorável ao desenvolvimento dos seus colaboradores. Mas, apesar desse importante favorecimento, ao tratar do financiamento em capacitação/qualificação dos profissionais que atuam na área de logística somente $26,7 \%$ afirmam que as organizações "sempre" financiam; para 33,4\% "às vezes" há financiamento e para 26,6\% "nunca" ou "quase nunca" (Tabela 21). 
Cabe observar que mais da metade das respostas do setor público manifestam que "quase nunca" ou "nunca" ocorre financiamento para capacitação/qualificação em logística. Embora o ambiente seja favorável ao autodesenvolvimento, na área de logística os treinamentos e capacitações são tidos como escassos.

Tabela 21 - Financiamento para capacitação/qualificação em logística.

\begin{tabular}{l|c|c|c|c|c|c}
\hline \multirow{2}{*}{} & \multicolumn{5}{c}{ HOSPITAIS } \\
\cline { 2 - 7 } & \multicolumn{2}{|c|}{ PÚBLICO } & \multicolumn{2}{c}{ PRIVADO } & \multicolumn{2}{c}{ TOTAL } \\
\cline { 2 - 7 } & $\mathrm{N}$ & $\%$ & $\mathrm{~N}$ & $\%$ & $\mathrm{~N}$ & $\%$ \\
\hline Sempre & 1 & 6,7 & 3 & 20,0 & 4 & 26,6 \\
Às vezes & 1 & 6,7 & 4 & 26,7 & 5 & 33,4 \\
Quase nunca & 1 & 6,6 & 1 & 6,7 & 1 & 13,3 \\
Nunca & 3 & 20,0 & - & - & 3 & 20,0 \\
Não sei & - & - & 1 & - & 1 & 6,7 \\
\hline TOTAL & 6 & 40,0 & 9 & 60,0 & 15 & 100,0 \\
\hline
\end{tabular}

Fonte: Dados da Pesquisa.

Durante as visitas de campo, observou-se que na área operacional da logística, os funcionários mais novos "aprendem o serviço" com os funcionários mais velhos que trabalham no setor há vários anos. Percebeu-se um distanciamento entre tal prática para a estratégia logística, pesando como prática da logística tradicional (BOWERSOX, CLOSS, 2001; MOURA, et al., 2003).

Enquanto observação do estudo empírico, apesar de não ser o foco deste estudo, observou-se certo grau de insatisfação e descontentamento por parte dos funcionários da área operacional da logística com certos procedimentos adotados em um hospital público. No entanto, em outras unidades há uma notória satisfação pelas conquistas, relacionando os trabalhos na área de logística aos resultados positivos do 
processo de acreditação o que permite deduzir que o compartilhamento dos resultados é favorecido.

Para E5, quando o financiamento ocorre é voltado para "gestores, coordenadores e lideres". E10 afirma que na organização onde trabalha há financiamento "para cursos de graduação e pós-graduação de até 50\%. Para cursos técnicos e outros cursos de informação, liderança - tem convênio com instituição para ensino à distância". Em outra organização estudada, E14 discorre que a "organização não financia cursos de graduação. Ela financia a participação em seminários, congressos e semelhantes, ou atividades "in company", além de um trabalho importante de consultoria na área de logística/suprimentos, em fase final de conclusão, que também contou com atividades de qualificação dos profissionais do Hospital".

Os dados apresentados na Tabela 21 evidenciam a preocupação do setor privado em qualificação profíssional e expõe que o setor público não prioriza a capacitação/qualificação dos servidores da área de logística, salientando que para manter os funcionários eminentes é demonstrar disposição para investir na educação do profissional (BOWERSOX, CLOSS, 2001).

Tabela 22 - Investimento em capacitação/qualificação nas diversas áreas, técnicas e administrativas.

\begin{tabular}{l|c|c|c|c|c|c}
\hline \multirow{2}{*}{} & \multicolumn{2}{|c|}{ HOSPITAIS } \\
\cline { 2 - 7 } & \multicolumn{2}{|c|}{ PÚBLICO } & \multicolumn{2}{c}{ PRIVADO } & \multicolumn{2}{c}{ TOTAL } \\
\cline { 2 - 7 } & $\mathrm{N}$ & $\%$ & $\mathrm{~N}$ & $\%$ & $\mathrm{~N}$ & $\%$ \\
\hline Sempre & 3 & 20,0 & 7 & 46,7 & 10 & 66,7 \\
Às vezes & - & - & 1 & 6,7 & 1 & 6,7 \\
Quase nunca & 2 & 13,3 & - & - & 2 & 13,3 \\
Nunca & - & - & - & - & - & - \\
Não sei & 1 & 6,7 & 1 & 6,6 & 2 & 13,3 \\
\hline TOTAL & 6 & 40,0 & 9 & 60,0 & 15 & 100,0 \\
\hline
\end{tabular}

Fonte: Dados da Pesquisa. 
Para $66,7 \%$ das respostas, as organizações estudadas "sempre" investem em qualificação/capacitação dos seus colaboradores; $26,6 \%$ responderam "quase nunca" e "não sei" responder e 6,7\% referem-se que "às vezes" acontece.

Ao comparar os resultados das Tabelas 21 e 22, enquanto foi apresentado 26,6\% "sempre" acontece financiamento para capacitação/qualificação em logística, ao tratar de investimento em capacitação/qualificação em outras áreas significa $66,7 \%$, o que evidencia que apesar do processo de implementação ser realidade nas organizações estudadas, a área de logística quanto à capacitação/qualificação ainda não é uma prioridade.

\subsection{LOGÍSTICA ENXUTA NO AMBIENTE HOSPITALAR}

Neste item apresentam-se os resultados das questões que envolvem a logística enxuta e a logística. Busca-se demonstrar que a logística enxuta não está implementada na cadeia produtiva hospitalar, e a mentalidade dos gestores é facilitadora no processo de implementação da logística hospitalar.

Das respostas obtidas, 26,6\% afirmam que os estoques são sempre baixos em todos os setores, porém, para 40\% isso ocorre "às vezes" e para 33,3\% "quase nunca" e "nunca" acontece. E3 afirma que é muito difícil a prática hospitalar com baixos estoques "devido à complexidade e particularidade do Hospital". E5 informa que nas "Unidades de Internação o estoque é baixo e que nas Farmácias Satélites o estoque é para três dias, com reposição diária”. 
Tabela 23 - Níveis de estoque baixos em todos os setores.

\begin{tabular}{l|c|c|c|c|c|c}
\hline \multirow{2}{*}{} & \multicolumn{2}{|c|}{ HOSPITAIS } \\
\cline { 2 - 7 } & \multicolumn{2}{|c|}{ PÚBLICO } & \multicolumn{2}{c}{ PRIVADO } & \multicolumn{2}{c}{ TOTAL } \\
\cline { 2 - 7 } & $\mathrm{N}$ & $\%$ & $\mathrm{~N}$ & $\%$ & $\mathrm{~N}$ & $\%$ \\
\hline Sempre & 1 & 6,6 & 3 & 20,0 & 4 & 26,6 \\
Às vezes & 1 & 6,7 & 5 & 33,3 & 6 & 40,0 \\
Quase nunca & 3 & 20,0 & 1 & 6,7 & 4 & 26,7 \\
Nunca & 1 & 6,7 & - & - & 1 & 6,7 \\
Não sei & - & - & - & - & - & - \\
\hline TOTAL & 6 & 40,0 & 9 & 60,0 & 15 & 100,0 \\
\hline
\end{tabular}

Fonte: Dados da Pesquisa.

No setor privado, do universo de 60,0\%, as respostas "sempre" e "às vezes" acontece significam 53,3\% aproximando-se da literatura. Há um distanciamento em relação ao setor público ao apresentar que mais de metade das respostas desse setor correspondem a "quase nunca" e "nunca" acontece. (WOMACK e JONES, 1998).

Para E10 "As unidades de atendimento (clinicas) não têm e não controlam estoques, é a Farmácia que faz, porém, no Diagnóstico (imagem e laboratório), eles têm controle próprio do estoque, justificado pelo controle rigoroso de temperatura de determinados itens. Para os demais itens do laboratório, o controle é realizado pela área de suprimentos". E13 informa que "ainda têm 240 leitos supridos com dose coletiva e planeja-se alterar para doses individualizadas”.

Um dos pontos defendidos na literatura sobre logística enxuta para eliminação de qualquer desperdício dos estoques em processo é o fluxo contínuo de materiais, o que não ocorre na totalidade dos hospitais estudados. Em um dos casos estudados não há controle dos insumos após a dispensação dos materiais e medicamentos para as áreas ou setores, distanciando-se da literatura e não apresentando controle logístico do estoque em processo (WOMACK e JONES, 1998; 
BALLOU, 2007; CHRISTOPHER, 1997), o que favorece para elevados valores financeiros empatados em estoque com deformação no capital de giro, oculta a "visibilidade" da demanda real do paciente final, além de riscos à obsolescência, entre outros prejuízos.

A abordagem tradicional do lote econômico e do ponto de ressuprimento, ocasionam estoques de segurança em níveis superiores ao necessário para garantir funcionamento do sistema e gera descapitalização da organização hospitalar. A filosofia JIT requer entrega ao cliente de pequenas quantidades e mais freqüentes no tempo exato de suas necessidades, o que representa um desafio ao gerenciamento logístico.

Em relação aos estoques, durante as visitas nas unidades de internação observou-se que mesmo quando individualizados há preocupação, por parte dos profissionais da área de enfermagem, em manter alguns itens em estoque, motivados por insegurança no tempo de reposição.

Tabela 24 - Filosofia just-in-time e compressão de prazos.

\begin{tabular}{l|c|c|c|c|c|c}
\hline \multirow{2}{*}{} & \multicolumn{7}{|c|}{ HOSPITAIS } \\
\cline { 2 - 7 } & \multicolumn{2}{|c|}{ PÚBLICO } & \multicolumn{2}{c}{ PRIVADO } & \multicolumn{2}{c}{ TOTAL } \\
\cline { 2 - 7 } & $\mathrm{N}$ & $\%$ & $\mathrm{~N}$ & $\%$ & $\mathrm{~N}$ & $\%$ \\
\hline Sempre & 2 & 13,3 & 1 & 6,7 & 3 & 20,0 \\
Às vezes & - & - & 4 & 26,7 & 4 & 26,7 \\
Quase nunca & 2 & 13,3 & 1 & 6,7 & 3 & 20,0 \\
Nunca & 2 & 13,3 & 2 & 13,3 & 4 & 26,7 \\
Não sei & - & - & 1 & 6,7 & 1 & 6,7 \\
\hline TOTAL & 6 & 40,0 & 9 & 60,0 & 15 & 100,0 \\
\hline
\end{tabular}

Fonte: Dados da Pesquisa.

A análise da Tabela 24 demonstra que $20 \%$ dos participantes identificam a filosofia JIT e compressão de prazos nas organizações que trabalham; 
$26,7 \%$ entendem que "às vezes" acontece. A somatória das respostas "quase nunca", "nunca" e "não sei" corresponde a 53,4\%.

Apesar de 20\% dos entrevistados afirmarem que "sempre" acontece e $26,7 \%$ que "às vezes", no campo observação foi acrescentado, pela maioria deles, que JIT no ambiente hospitalar é impraticável.

E3 e E12 afirmam que "JIT não se aplica em hospitais"; para E10 talvez aconteça com mat/méd não padronizados. E13 coloca que não se aplica, já que "a programação de estoque é para três meses, com recebimento mensal". E8 traz que "JIT na área hospitalar é muito dificil - encontrar fornecedores no Brasil com este perfil para o atendimento do hospital não é realidade aqui".

Diferentemente do ambiente industrial esta pesquisa demonstrou que há distanciamento entre o aporte teórico (CHING, 1999; WOMAK, JONES, 1998; BALLOU, 2007) e prática da logística enxuta aplicada à manufatura e aos serviços de saúde; neste caso os hospitais estudados.

Tabela 25 - Logística aplicada com enfoque sistêmico e não há desperdício de medicamentos e materiais.

\begin{tabular}{l|c|c|c|c|c|c}
\hline \multirow{2}{*}{} & \multicolumn{9}{|c}{ HOSPITAIS } \\
\cline { 2 - 7 } & \multicolumn{2}{|c|}{ PÚBLICO } & \multicolumn{2}{c}{ PRIVADO } & \multicolumn{2}{c}{ TOTAL } \\
\cline { 2 - 7 } & $\mathrm{N}$ & $\%$ & $\mathrm{~N}$ & $\%$ & $\mathrm{~N}$ & $\%$ \\
\hline Sempre & 1 & 6,7 & 1 & 6,7 & 2 & 13,4 \\
Às vezes & 2 & 13,3 & 7 & 46,7 & 9 & 60,0 \\
Quase nunca & 2 & 13,3 & 1 & 6,7 & 3 & 20,0 \\
Nunca & 1 & 6,6 & - & - & 1 & 6,6 \\
Não sei & - & - & - & - & - & - \\
\hline TOTAL & 6 & 40,0 & 9 & 60,0 & 15 & 100,0 \\
\hline
\end{tabular}

Fonte: Dados da Pesquisa. 
Questionados se a logística é aplicada com enfoque sistêmico, e se não há desperdício de medicamentos e materiais (Tabela 25), 13,4\% afirmam que "sempre" acontece; por outro lado, $60 \%$ afirmam que "às vezes" acontece; $26,6 \%$ respondem que "quase nunca" e "nunca" acontece. Percebe-se, com veemência, que o enfoque é sistêmico e não ocorre desperdício somente para 13,3\% dos entrevistados; os demais $(73,4 \%)$ afirmam acontecer, em diferentes graus.

De acordo com E3, devido à complexidade de alguns produtos, principalmente os do tipo Z, "podem não ser usados, mas precisa manter em estoque". E6 manifesta que na alta complexidade "alguns itens da curva Z obrigatórios sem giro e alguns produtos importados".

E5 afirma que "temos estoque de medicamentos manipulados cuja validade é de três meses, acarretando perdas". E8 lembra-se dos antídotos, e "neste caso, tomara que ocorra mesmo - que vença e seja descartado sem que o seu uso seja necessário"; já E9 relaciona aos "materiais de uso esporádico, alteração da equipe ou mudança rápida de técnica cirúrgica". E12 afirma que "não há controle dos materiais nas clínicas".

Tabela 26 - Logística enxuta e valor ao paciente.

\begin{tabular}{l|c|c|c|c|c|c}
\hline \multirow{2}{*}{} & \multicolumn{5}{|c|}{ HOSPITAIS } \\
\cline { 2 - 7 } & \multicolumn{2}{|c|}{ PÚBLICO } & \multicolumn{2}{c|}{ PRIVADO } & \multicolumn{2}{c}{ TOTAL } \\
\cline { 2 - 7 } & $\mathrm{N}$ & $\%$ & $\mathrm{~N}$ & $\%$ & $\mathrm{~N}$ & $\%$ \\
\hline Sempre & 2 & 13,3 & 4 & 26,7 & 6 & 40,0 \\
Às vezes & 3 & 20,0 & 1 & 6,7 & 4 & 26,7 \\
Quase nunca & - & - & 2 & 13,3 & 2 & 13,3 \\
Nunca & 1 & 6,7 & 1 & 6,7 & 2 & 13,3 \\
Não sei & - & - & 1 & 6,7 & 1 & 6,7 \\
\hline TOTAL & 6 & 40,0 & 9 & 60,0 & 15 & 100,0 \\
\hline
\end{tabular}

Fonte: Dados da Pesquisa. 
A análise da Tabela 26 expõe que $66,7 \%$ dos participantes da pesquisa reconhecem, em diferentes graus, que a logística enxuta agrega valor ao paciente; para $26,7 \%$ "às vezes" acontece, aproximando-se do enfoque estratégico em que o cliente é o destino dos esforços logísticos (CHRISTOPHER, 1997; MOURA et al., 2003; WOMACK e JONES, 2006).

A soma das respostas referentes à "quase nunca", "nunca" acontece e "não sei" corresponde a 33,3\%, representando um terço das respostas, deduz-se, entre outros aspectos, à falta de integração do sistema logístico na amplitude total nas organizações estudadas.

E6 informa que o hospital passa por mudanças e que "está implantando área de preparo de medicamento nas farmácias" e E13 entende que "agrega valor onde a logistica está integrada, como, por exemplo, na área ambulatorial”. Para E8, "garante-se que continua tendo o cliente pelo trabalho em logística e não o contrário”. Na percepção de E15 "o cliente final não sente”.

Tabela 27 - Mentalidade enxuta dos gestores facilita adoção de técnicas de favorecimento a otimização do tempo e dos recursos.

\begin{tabular}{l|c|c|c|c|c|c}
\hline \multirow{2}{*}{} & \multicolumn{5}{|c|}{ HOSPITAIS } \\
\cline { 2 - 7 } & \multicolumn{2}{|c|}{ PÚBLICO } & \multicolumn{2}{c}{ PRIVADO } & \multicolumn{2}{c}{ TOTAL } \\
\cline { 2 - 7 } & $\mathrm{N}$ & $\%$ & $\mathrm{~N}$ & $\%$ & $\mathrm{~N}$ & $\%$ \\
\hline Sempre & 2 & 13,3 & 5 & 33,3 & 7 & 46,6 \\
Às vezes & 2 & 13,3 & 4 & 6,7 & 6 & 40,0 \\
Quase nunca & - & - & - & - & - & - \\
Nunca & 1 & 6,7 & - & - & 1 & 6,7 \\
Não sei & 1 & 6,7 & - & - & 1 & 6,7 \\
\hline TOTAL & 6 & 40,0 & 9 & 60,0 & 15 & 100,0 \\
\hline
\end{tabular}

Fonte: Dados da Pesquisa. 
A Tabela 27 evidencia a percepção dos entrevistados em relação à incorporação da mentalidade enxuta pelos gestores hospitalares como ferramenta facilitadora na adoção de técnicas que favoreçam a otimização de tempo e recursos. De $86,7 \%$ das respostas $46,7 \%$ consideram que isso "sempre acontece" e para $40,0 \%$ "às vezes" acontece. Para 6,7\% "nunca" acontece e 6,7\% não responderam à questão.

No campo observação, o respondente E8 manifestou-se quanto à importância da adoção da mentalidade enxuta e enfatizou que "quanto aos recursos, sempre acontece, porém, quanto à otimização de tempo, desconheço que esteja ocorrendo ações neste sentido no hospital". Nas palavras de E15, "otimiza recursos e gasta-se mais tempo. Aqui no hospital, tempo e recursos são antagônicos”. E12 afirma que "a nova direção tem proposta de mudança".

Apesar da maioria dos executivos reconhecerem a importância da mentalidade enxuta dos gestores para a otimização de tempo e de recursos, nos discursos foi enfatizada a preocupação em relação a recursos enquanto que a variável tempo foi citada como não implementada e até mesmo como antagônica em relação a recursos, divergindo da propositura da logística enxuta quanto ao encurtamento dos prazos e redução de tempo (CHRISTOPHER, 1997; WOMACK e JONES, 2006).

A análise da Tabela 28 evidencia que $40,0 \%$ dos executivos entendem que há coordenação entre suprimentos e as diversas áreas por meio de comitês ou grupos de trabalho, que se reúnem para solução de problemas e propositura de melhorias e assim garantem integração dos fluxos de materiais, informacionais e financeiro; $33,3 \%$ deles percebem que isso "às vezes" acontece, e correspondem a $26,7 \%$ as respostas "quase nunca" e "não sei". 
Tabela 28 - Participação dos comitês e grupos de trabalho na integração dos fluxos logísticos

\begin{tabular}{l|c|c|c|c|c|c}
\hline \multirow{2}{*}{} & \multicolumn{5}{|c}{ HOSPITAIS } \\
\cline { 2 - 7 } & \multicolumn{2}{|c|}{ PÚBLICO } & \multicolumn{2}{c}{ PRIVADO } & \multicolumn{2}{c}{ TOTAL } \\
\cline { 2 - 7 } & $\mathrm{N}$ & $\%$ & $\mathrm{~N}$ & $\%$ & $\mathrm{~N}$ & $\%$ \\
\hline Sempre & 1 & 6,7 & 5 & 33,3 & 6 & 40,0 \\
Às vezes & 2 & 13,3 & 3 & 20,0 & 5 & 33,3 \\
Quase nunca & 1 & 6,7 & - & - & - & 6,7 \\
Nunca & - & - & - & - & - & - \\
Não sei & 2 & 13,3 & 1 & 6,7 & 3 & 20,0 \\
\hline TOTAL & 6 & 40,0 & 9 & 60,0 & 15 & 100,0 \\
\hline
\end{tabular}

Fonte: Dados da Pesquisa.

E6 remete à Comissão de Farmácia e Materiais; E12 coloca que começa um movimento nesse sentido, quanto a "OPME foi instituído grupo de padronização destes materiais que são mais caros". Para E15, o grupo de padronização atua para “aproximação e reduzir o gap da área de suprimentos”. E11 traz a presença do "centro de infra-estrutura e logística que é ligado ao núcleo de infra-estrutura e logística da organização".

A literatura referente à logistica enxuta também aponta para melhorias do sistema por meio da padronização de processos e de insumos (WOMACK, 1996). Favorecendo a implantação dos protocolos, a Organização Mundial da Saúde tem desenvolvido vários esforços no intuito de estimular a criação de políticas de saúde baseadas em evidência científica e dirigidas especificamente ao uso racional de materiais e medicamentos (OMS, 2000).

A padronização visa definir a melhor forma de realização de uma atividade, buscando participação e consenso de todos os participantes no processo, de 
forma a atingir o resultado esperado (previsibilidade), com melhor qualidade e menor custo.

$\mathrm{Na}$ área da saúde, ao assumir determinado protocolo é possível melhorar o sistema de compras, de maneira a atender os critérios de disponibilização do que se quer, quando se necessita, porém, cabe discussão quanto ao cuidado para que não se torne camisa de força para os profissionais envolvidos, obrigando-os a utilizarem o mínimo possível de procedimentos e os materiais e medicamentos mais baratos e não necessariamente os mais indicados. Existem protocolos de operadoras, de hospitais, de profissionais e até de fornecedores, como os da indústria farmacêutica (VECINA e MALIK, 2007), o que destoa do foco principal que é atender a pessoa do paciente.

\subsection{LOGÍSTICA REVERSA}

Dos participantes, 33,3\% informam que a organização que trabalham realiza sistematicamente ações de reuso, reutilização e reciclagem de resíduos, mas, para $20 \%$ isso "às vezes" acontece. Observou-se predominância de 46,7\% ao somar as respostas que correspondem a "quase nunca" acontece, "não sei".

Quanto às informações complementares, E3 e E6 consideram que há devolução de materiais não utilizados. E7, E10, E12 e E15 informam que "o hospital tem um programa" e para dois destes "o setor de voluntários atua também no programa e os recursos são convertidos em outras ações de atendimento". Para outro participante "grupo de reuso de artigos médico-hospitalares", e E15 finaliza que "todos os setores participam do programa". 
Tabela 29 - Sistematização do uso, reuso e reciclagem .

\begin{tabular}{l|c|c|c|c|c|c}
\hline \multirow{2}{*}{} & \multicolumn{7}{|c|}{ HOSPITAIS } \\
\cline { 2 - 7 } & \multicolumn{2}{|c|}{ PÚBLICO } & \multicolumn{2}{c}{ PRIVADO } & \multicolumn{2}{c}{ TOTAL } \\
\cline { 2 - 7 } & $\mathrm{N}$ & $\%$ & $\mathrm{~N}$ & $\%$ & $\mathrm{~N}$ & $\%$ \\
\hline Sempre & 2 & 13,3 & 3 & 20,0 & 5 & 33,3 \\
Ȧs vezes & 2 & 13,3 & 1 & 6,7 & 3 & 20,0 \\
Quase nunca & 2 & 13,3 & 1 & 6,7 & 3 & 20,0 \\
Nunca & - & - & - & - & - & - \\
Não sei & - & - & 4 & 26,6 & 4 & 26,7 \\
\hline TOTAL & 6 & 40,0 & 9 & 60,0 & 15 & 100,0 \\
\hline
\end{tabular}

Fonte: Dados da Pesquisa.

Durante as visitas, notou-se que todas as organizações estudadas contam com Plano de Gerenciamento de Resíduos de Serviços de Saúde, e que monitoram o desempenho de ações voltadas ao reuso, reutilização ou reciclagem. Essas atividades sistematizadas são partes dos componentes da logística reversa, representando a existência de canais reversos de distribuição do pós-consumo (LEITE, 2003; HAMZAGIC, KAMIMURA e PHILIPI, 2005).

Observou-se, também, que nos hospitais em que o posicionamento estratégico de suprimento contempla a dispensação dos materiais e medicamentos individualizados, há favorecimento ao fluxo multidirecional dos materiais não utilizados nas clínicas. 


\subsection{DESEMPENHO LOGÍSTICO}

O desempenho logístico, como variável de controle, representa a eficiência logística da organização. Atualmente a avaliação do desempenho das atividades e processos ao longo da cadeia logística assumiu uma dimensão estratégica.

As características do sistema tradicional estão fortemente arraigadas à cultura de muitas organizações, incluindo as hospitalares, e são em grande parte herança da abordagem clássica da administração, que tinha como foco aumentar a produtividade com a melhoria dos métodos de trabalho. O ambiente mercadológico atual público e privado aponta em direção à necessidade de os sistemas de medida de desempenho estarem alinhados aos objetivos estratégicos das organizações.

Questionados em relação à formalização do processo de planejamento de suprimentos, ao alinhamento dos objetivos e das diretrizes da organização, se as diversas áreas participam, se os resultados são monitorados, e o desempenho logístico é avaliado, 46,7\% dos executivos informam que isso "sempre" acontece; $40 \%$ que acontece "às vezes". Ao apresentar o reconhecimento de $86,7 \%$ das respostas positivas em diferentes graus, significa aderência ao preconizado na literatura (BOWERSOX, CLOSS, 2001; LAMBERT ET AL., 2001; RODRIGUEZ, 2005). Para 13,3\% dos participantes isso "quase nunca" acontece e representam a voz do setor público o que reflete a diferente velocidade desse setor no processo de mudança e implementação da área de logística.

A maioria das respostas não foi justificada ou acrescida, porém E3 informa que isso "ocorre conforme politica da organização". Já para E15 a organização "fornece alguns indicadores, porém, não há confiança". 
Tabela 30 - Processo de planejamento de suprimentos é formalizado, os objetivos e as diretrizes são alinhadas com as diretrizes da organização, as diversas áreas do hospital participam e os resultados são monitorados.

\begin{tabular}{l|c|c|c|c|c|c}
\hline \multirow{2}{*}{} & \multicolumn{9}{|c|}{ HOSPITAIS } \\
\cline { 2 - 7 } & \multicolumn{2}{|c|}{ PÚBLICO } & \multicolumn{2}{c}{ PRIVADO } & \multicolumn{2}{c}{ TOTAL } \\
\cline { 2 - 7 } & $\mathrm{N}$ & $\%$ & $\mathrm{~N}$ & $\%$ & $\mathrm{~N}$ & $\%$ \\
\hline Sempre & 2 & 13,4 & 5 & 33,3 & 13 & 46,7 \\
Às vezes & 2 & 13,3 & 4 & 26,7 & 6 & 40,0 \\
Quase nunca & 2 & 13,3 & - & - & 2 & 13,3 \\
Nunca & - & & - & - & - & - \\
Não sei & - & & - & & - & - \\
\hline TOTAL & 6 & 40,0 & 9 & 60,0 & 15 & 100,0 \\
\hline
\end{tabular}

Fonte: Dados da Pesquisa.

Quanto à avaliação sistematizada do desempenho logístico e ações de melhoria nos fluxos logísticos (Tabela 31), 40\% dos executivos afirmam que "sempre" acontece; para 20\% "às vezes" acontece; a somatória: "quase nunca", "nunca" e "não sei" totalizam $40 \%$ das respostas.

Tabela 31 - Desempenho logístico é avaliado sistematicamente e melhora fluxos.

\begin{tabular}{l|c|c|c|c|c|c}
\hline \multirow{2}{*}{} & \multicolumn{9}{|c|}{ HOSPITAIS } \\
\cline { 2 - 7 } & \multicolumn{2}{|c|}{ PÚBLICO } & \multicolumn{2}{c}{ PRIVADO } & \multicolumn{2}{c}{ TOTAL } \\
\cline { 2 - 7 } & $\mathrm{N}$ & $\%$ & $\mathrm{~N}$ & $\%$ & $\mathrm{~N}$ & $\%$ \\
\hline Sempre & 1 & 6,7 & 5 & 33,3 & 6 & 40,0 \\
Às vezes & 1 & 6,7 & 2 & 13,3 & 3 & 20,0 \\
Quase nunca & 1 & 6,7 & 2 & 13,3 & 3 & 20,0 \\
Nunca & 2 & 13,3 & - & - & 2 & 13,3 \\
Não sei & 1 & 6,7 & - & - & 1 & 6,7 \\
\hline TOTAL & 6 & 40,0 & 9 & 60,0 & 15 & 100,0 \\
\hline
\end{tabular}

Fonte: Dados da Pesquisa. 
E3 afirma que "é avaliado de acordo com relatórios gerenciais mensais". E10 e E11 informam que é "através do sistema". E15 cita que "avalia para a demanda da área em relação a atendimento de pedido" e que "falta avaliar à luz do cliente interno".

Ao apresentar "quase nunca", "nunca" e "não sei" para 40\% das respostas em relação ao desempenho logístico se é avaliado sistematicamente e melhora os fluxos e ao cruzar com os resultados da Tabela 30, deduz-se que há reconhecimento de que as organizações tenham formalizado os processos de planejamento de suprimentos, há alinhamento entre as diretrizes logísticas e da organização, há participação multidisciplinar e monitoramento dos resultados, porém, a avaliação sistemática do desempenho logístico está em fase de implementação e os hospitais encontravam-se em diferentes estágios no período de realização desta pesquisa e para algumas unidades, o monitoramento sistemático do desempenho logístico e melhoria dos fluxos é um desafio a ser alcançado.

Questionados sobre como o desempenho logístico é avaliado, foram obtidas as respostas:

"Através do relatório gerencial, que contempla as principais informações" (E3).

"Até pouco tempo era empirica - sensação de atrasos constantes. Com a introdução da capa de lote e bipagem, chegou-se a controles de tempo nas etapas do processo. Outro indicador oficioso é o tamanho dos estoques locais, que refletem insegurança no sistema de abastecimento" (E4).

"Por meio de compra de medicamentos não padronizados; indicadores de avaliação farmacêutica; indicadores de atrasos de dispensação" (E5). 
"Relatório de gestão e compras de urgência" (E6).

"É avaliado de acordo com a satisfação do cliente, a meta é atender $90 \%$ dos pedidos. O monitoramento é feito por meio de relatórios do sistema com atendimento de cada solicitação (giro de estoque, margem, insumos, volume comprado, nivel de atendimento). Uso do sistema para tomada de decisões e outras informações. Por exemplo, recebo a informação de que $x$ insumo será alterado. $O$ hospital realiza de 1 a 2 transplantes de figado, a partir de 2001, passou a ser referência para o SUS, e a partir dai, foi necessário fazer o planejamento da programação de materiais e de compras, saímos de um transplante de figado ao semestre para 5 a 6 por mês"(E8).

"Para a diretoria o relatório é mensal, mas os fechamentos são mensais e diários no sistema, para decisões diárias de planejamento" (E9).

"Por meio do sistema" (E11).

"Desconheço, faço parte do grupo de indicadores e isso não foi discutido".(E12)

"Esses indicadores estão sendo construidos, além disso, iniciamos a implantação, em 01/09, de um novo sistema integrado de gestão hospitalar, que contribuirá, em muito, para a implantação dos indicadores de desempenho logístico e de suprimentos." (E14).

"Na área de enfermagem, utilizamos o percentual de pedidos, apreciamos mensalmente: consumo dos itens; 
padronização dos itens (grupo de padronização); quanto tem parado em estoque; giro de estoque. A Enfermagem não tem acesso aos demais dados ou indicadores" (E15).

Indicadores citados durante as entrevistas:

capa de lote e bipagem, o tamanho dos estoques locais, compra de medicamentos não padronizados; indicadores de avaliação farmacêutica; indicadores de atrasos de dispensação; compras de urgência; satisfação do cliente, a meta é atender 90\% dos pedidos; (giro de estoque, margem, insumos, volume comprado, nível de atendimento; desconheço, faço parte do grupo de indicadores e isso não foi discutido; enfermagem: percentual de pedidos, apreciamos mensalmente: consumo dos itens; padronização dos itens (grupo de padronização); quanto tem parado em estoque; giro de estoque.

Quanto ao método definido para a mensuração dos indicadores, os executivos entrevistados afirmam: "através dos indicadores mensais, conseguimos tomar ação, entre eles, itens sem consumo, urgências, percentual de quebra" (E3). "o indicador tempo é novo, tem sido consultado aparentemente por demanda, ou seja, queixa de atraso (E4). "é trimestral e mensal" (E5). "as ações são tomadas de acordo com variação do relatório de gestão" (E6). "por meio do sistema" (E11).

Durante as visitas foram informados alguns indicadores utilizados nas organizações estudadas, foram identificados e classificados nesta pesquisa em: nível de serviço, tempo, custo, produtividade (BOWERSOX, CLOSS, 2001). 
Quadro 6 - Categorização dos indicadores de desempenho logístico

\begin{tabular}{|c|c|c|c|c|c|c|}
\hline & \multirow[t]{2}{*}{ Indicador de Desempenho Logístico } & \multicolumn{5}{|c|}{ Amostra } \\
\hline & & $\mathrm{HA}$ & $\mathrm{HB}$ & $\mathrm{HC}$ & HD & $\mathrm{HE}$ \\
\hline $\begin{array}{l}\text { Nível } \\
\text { Serviço }\end{array}$ & $\begin{array}{l}\% \text { de Entregas realizadas dentro do } \\
\text { prazo e atendendo as quantidades e } \\
\text { especificações de pedido. } \\
\% \text { de Itens solicitados e itens } \\
\text { atendidos. }\end{array}$ & $\mathrm{x}$ & & & & \\
\hline Tempo & $\begin{array}{l}\text { Giro de Estoque. } \\
\text { Tempo de permanência do material } \\
\text { (Classe A, B e C) no depósito. } \\
\text { Tempo de permanência do estoque } \\
\text { em processo. } \\
\text { Tempo médio de busca por insumos. } \\
\text { Tempo de resposta às demandas do } \\
\text { cliente. } \\
\text { Lenta movimentação. }\end{array}$ & $\mathrm{x}$ & $\begin{array}{l}\mathrm{x} \\
\mathrm{x} \\
\mathrm{x}\end{array}$ & & & \\
\hline Custo & & & & & & \\
\hline Produtividade & & & & & & \\
\hline
\end{tabular}

Fonte: Dados da Pesquisa.

Ao não apresentar medidas de desempenho logístico demonstra presença da logística tradicional e certo distanciamento do aporte teórico de visão estratégica da logística, que demanda fixação de objetivos a serem atendidos atingidos pelos serviços logísticos e, além disso, a adoção de medidas corretivas (BOWERSOX, CLOSS, 2001; CHRISTOPHER, 1997; LAMBERT, STOCK e VATINE, 1999). 


\section{CONCLUSÃO}

Os resultados desta pesquisa permitem afirmar que recentemente, em diferentes formas e graus, os novos conceitos de logística/Gestão da Cadeia de Suprimentos vem sendo incorporados nas organizações hospitalares estudadas. A maioria optou por modelo de gestão próprio e uma delas, por terceirização da logística de distribuição interna.

Com base nos discursos dos participantes, o objetivo da logística no ambiente hospitalar resume-se em suprir toda a demanda de acordo com as necessidades dos pacientes e das diretrizes da organização, garantindo segurança, qualidade, inovação, prazo e custo.

Nas organizações privadas, o ambiente turbulento advindo da economia globalizada, da estabilização da moeda brasileira e de pressões para mudança do modelo pautado na autonomia do prestador para decidir os procedimentos julgados necessários para o tratamento do paciente e a remuneração ocorre conforme os serviços efetuados que estimula o aumento de despesas assistenciais, agrega valor ao prestador e não exige rigoroso controle de custos por parte da organização prestadora do serviço de saúde; tem motivado para a implementação dos novos conceitos estudados nesta pesquisa, impulsionados pela própria sustentabilidade e por alavancar vantagem competitiva.

Um ponto importante que pesa na decisão de aquisição de tecnologia, incluindo o acompanhamento do desenvolvimento logístico, é a capacidade de investimento dos hospitais estudados, porém, não bastam apenas investimentos, os gestores precisam estar alinhados às políticas de saúde, às diretrizes da organização e aderirem à mentalidade enxuta defendida aqui enquanto uma filosofia de otimizar tempo e recurso para melhor atender a pessoa do paciente. 
Diante da interpretação dos resultados, conclui-se que:

- as organizações estudadas vêm incorporando recentemente os conceitos de logística, e, a cadeia de suprimentos ainda não foi redefinida em todas as unidades de análise para essa perspectiva mais ampla do novo paradigma da logística.

- reconhece-se o potencial de contribuição da logística como fonte de vantagem competitiva, que deve ser tratada como caráter estratégico. Na prática, em algumas das organizações estudadas ainda é tratada como operacional, por não apresentar indicadores de desempenho logístico, e, consequentemente, não possibilitar a avaliação do alinhamento dessa área à estratégia da organização.

- é necessário ampliar a visão dos hospitais públicos quanto à sua participação na cadeia de suprimentos.

- a logística enxuta não está implementada na cadeia produtiva hospitalar e na percepção dos executivos entrevistados, o Just-in-time não se aplica integralmente no ambiente hospitalar, e, a mentalidade dos gestores é facilitadora no processo de implementação da logística hospitalar e não foram identificadas, nas organizações estudadas, iniciativas de serviço enxuto.

- o sistema logístico de cada um dos estabelecimentos estudados reserva diferentes características e estão em diferentes estágios, sintetizando a caracterização geral em:

\section{- Fornecedores}

O relacionamento e integração com os fornecedores não está consolidado na sua totalidade em parcerias colaborativas em que se buscam os mesmos resultados pela sinergia entre os elos da cadeia produtiva, uma recomendação é o relacionamento de parceria com os profissionais médicos aproximando-os enquanto elo da cadeia; é inexpressiva a redução do número de fornecedores. 
Embora seja perceptível a preocupação e esforços dos executivos na aproximação e sensibilização dos fornecedores, caminhando em relação ao preconizado na literatura, é exigido ainda um efetivo processo de desenvolvimento dos fornecedores na área da saúde. É necessário pensar em um nível de coordenação que extrapole os limites das organizações para cumprir a integração de funções internas dentro dos hospitais em toda a cadeia.

As organizações públicas e privadas avaliam, em diferentes graus, os seus fornecedores.

\section{- Suprimento}

Os hospitais públicos e privados enfrentam problemas de abastecimento, o setor privado manifestou capacidade de planejamento e aproximação e sinergia entre os profissionais que compõem a cadeia produtiva na busca de soluções, os principais problemas apontados foram em relação ao mercado de produtos importados.

O setor público apesar de demonstrar busca por melhoria nas ferramentas de gestão, apresenta dificuldades no planejamento do material por processo e ainda padece por falta de insumos no momento da operacionalização do procedimento, com prejuízo dos integrantes da instituição e do paciente.

A adesão à tecnologia, como a prática do e-procurement vêm permitindo que as organizações hospitalares descubram e explorem oportunidades de mercado de suprimento; nas organizações públicas, a utilização das compras eletrônicas demonstraram agilidade nos processos de compras.

- Distribuição e Suporte à Produção 
O posicionamento logístico no atendimento ao paciente internado é conformado pela adoção de dois caminhos: o de antecipação da demanda e o de resposta rápida.

\section{- Fluxos}

O fluxo de materiais difere entre os hospitais estudados, explicitando que há um desnivelamento de investimentos em tecnologia e automação na área de logística e sistema integrado do fluxo de materiais e informação e controle de toda a área de suprimentos em todo o processo.

- os fluxos de materiais, financeiro e de informação, embora em processo de evolução, precisam ser melhorados e integrados, os estoques na cadeia de suprimento dos hospitais não são baixos; a integração plena do sistema logístico é um desafio a ser alcançado no processo evolutivo do novo paradigma da logística. Outro desafio é o equilíbrio entre eficiência e responsividade da cadeia de suprimentos da saúde.

- os indicadores logísticos estão sendo desenvolvidos, de forma diversificada nas organizações estudadas. As organizações públicas apresentam indicadores voltados para controle e avaliação dos fornecedores; duas do setor privado demonstram indicadores voltados à avaliação de valores e de qualidade no nível de serviço, e uma delas, não monitora.

- Em relação ao Fator Humano:

- as organizações privadas demonstraram flexibilidade em adequar aos novos cargos e posições; nas organizações públicas, a legislação da estrutura organizacional tem sido uma limitação para acompanhar a velocidade das mudanças.

- Há preocupação em promover o aprendizado e troca de experiências entre os colaboradores, o ambiente organizacional é percebido como favorável ao 
autodesenvolvimento porém os investimentos em capacitação/qualificação na área de logística no setor público não é priorizado.

Uma preocupação em relação à forma da incorporação do novo paradigma da logística no ambiente hospitalar está na contratação de profissionais e empresas que estejam vinculados aos princípios tanto operacionais quanto filosóficos da gestão da saúde e políticas de saúde, tomando cuidado para que o "culto" à manufatura não se sobreponha ou secundarize a pessoa do paciente.

Os gestores devem estar alinhados à gestão de saúde e no árduo trabalho de enfrentar a correnteza de tantos interesses não esmorecer em arquear diretamente o alvo, que é o tratamento e atenção à pessoa humana. 


\section{REFERÊNCIAS}

ALMEIDA, C. O Mercado Privado de Serviços de Saúde no Brasil:Panorama Atual e Tendências na Assistência Suplementar. Textos para Discussão n. 599. Brasília, IPEA, 1998.

ALMEIDA, E.S.; CASTRO, C.G.J.; Planejamento e Programação em Saúde, 1999 (mimeografado - anotações de aulas).

ANGARAN, D. M. Clinical pharmacy saves money and lives - So what's new? Pharmacotherapy, Boston, V. 19, n. 12, p. 1352-1353, jul. 1999.

ANS. Caderno de Informação da Saúde Suplementar da ANS: beneficiários, operadoras e planos. Edição de dezembro de 2007. Rio de Janeiro: ANS, 2007.

BAHIA, L. Planos e Seguros Saúde: padrões e mudanças das relações entre o público e o privado no Brasil. [Tese de Doutorado]. Rio de Janeiro: ENSP/FIOCRUZ; 1999.

BALLOU, R. H. Logística empresarial: transporte, administração de materiais e distribuição física. São Paulo : Atlas, 1993.

BALlOU, R. H. Gerenciamento da cadeia de abastecimento: planejamento, organização e logística empresarial. 4. ed. Porto Alegre: Bookman, 2001.

BALlOU, R. H. Gerenciamento da cadeia de abastecimento: planejamento, organização e logística empresarial. 8. ed. Porto Alegre: Bookman, 2007.

BANCO MUNDIAL. Relatório sobre o Desenvolvimento Mundial 1993. Rio de Janeiro, Fundação Getúlio Vargas.

BARBIERI, J. C. Logística Hospitalar. São Paulo: Editora Saraiva, 2006. 
BARDIN, L. Análise de conteúdo. Trad. Luís Antero Reto e Augusto Pinheiro. Lisboa: Edições 70, 1977.

BERELSON, B. Content Analysis in Comunication Research. New York. University Press, 1971.

BERTAGLiA, P. R.B. Logística e Gerenciamento da Cadeia de Suprimentos. São Paulo: Editora Saraiva, 2005.

BITTAR, O.J.N.V. Formas de Atendimento em Saúde. Qualimetria nº61, Setembro, 1996.

BITTAR, O.J.N.V. Hospital: qualidade \& produtividade. São Paulo: Savier, 1997.

BITTAR, O.J.N.V. Hospitais: administração da qualidade e acreditação de organizações complexas. Porto Alegre: Da Casa, Cap. 1, 2004.

BITTAR, O.J.N.V. Inúmeros números do planejamento de saúde. Planejamento de Saúde: Conhecimento \& Ações. Secretaria de Estado da Saúde de São Paulo, 2006.

BORGES NETO, B. A. Programa de Reestruturação e Contratualização dos Hospitais de Ensino. In: BITTAR, O.J.N.; MAGALHÃES, A. Hospitais de Ensino no Estado de São Paulo. São Paulo: Secretaria de Estado da Saúde de São Paulo, 2007.

BOWERSOX, D. J.; DAUGHERTY, P.J., DROGE, C.L., ROGERS, D.S., WARDLOW, D.L. "Leading Edge logistics: competitive position for the 1990's". Oak Brook,III.: Council of Logistics Management, 1989.

BOWERSOX, D. J.; CLOSS, D. J. Logística empresarial: o processo de integração da cadeia de suprimento. São Paulo: Atlas, 2001.

BOWERSOX, D. J.; CLOSS, D. J.; COOPER, M. B. Gestão logística de cadeias de suprimentos. Porto Alegre: Bookman, 2007. 
BRAGA, J.M.C. e PAUlA, S.G. Saúde e Previdência. São Paulo, Editora CEBESHUCITEC, 1981.

BRANDT, R. A. Visão sobre o sistema de saúde no Brasil. Apresentação realizada em abril de 1998 na Mesa Redonda "A Saúde no Brasil”, São Paulo, 1998.

BRASIL. Ministério da Saúde. Portaria MS/SAS nº 376, 2000.

BRASIL. Ministério da Saúde. Manual Brasileiro de Acreditação Hospitalar. 3. d. Brasília: Ministério da Saúde, 2001.

BUSS,P. Assistência Hospitalar no Brasil (1984-1991): uma Análise preliminar baseada no Sistema de Informação Hospitalar do SUS. Informe Epidemiológico do SUS 2(2):5-42, mar/abr, 1993.

Carvalho, G.C.M. O Financiamento Público Federal do Sistema Único de Saúde 1988-2001, 2002. Tese de Doutorado, Faculdade de Saúde Pública Universidade de São Paulo.

CASTELAR, R. M. O Hospital no Brasil. In: CASTELLAR, R. M., MORDELET, P., GRABOIS, V. Gestão Hospitalar: um desafio para o hospital brasileiro. França: Édition ENS, 1995.

CAVAllini, M.E.; BISSON, M. P. Farmácia Hospitalar: Um Enfoque em Sistemas de Saúde. São Paulo: Manole, 2002.

CHING, H. Y. Gestão de estoque na cadeia logística integrada. $2^{\mathrm{a}}$. Edição. São Paulo: Atlas, 2001.

CHOPRA, S. MEINDL, P. Gerenciamento da cadeia de suprimentos: estratégia, planejamento e operação. São Paulo: Pearson Education do Brasil. Prentice Hall, 2004.

CHRISTOPHER, M. Logística e Gerenciamento da Cadeia de Suprimentos. São Paulo: Pioneira, 1997. 
COHN A.; ELIAS, P.E.M. Saúde no Brasil: políticas e organização de serviços. São Paulo: Cortez/Cedec, 1996.

CONFEDERAÇÃO DAS MISERICÓRDIAS DO BRASIL. Santas Casas da Misericórdia e Hospitais Filantrópicos. In: Cadernos da IX Conferência Nacional de Saúde, Brasília, Ministério da Saúde, 1992.

CORDEIRO, H. As Empresas Médicas. Rio de Janeiro. Ed. Graal, 1984.

CORDEIRO, H. A Indústria da Saúde no Brasil. Rio de Janeiro. Ed. Graal, 1980.

CORRÊA, H. L.; CORRÊA, C. A. Administração da produção e operações: manufatura e serviços uma abordagem estratégica. São Paulo: Atlas, 2004.

COSTA e RIBEIRO,J.M. (Org.) Política de Saúde e Inovação Institucional: uma agenda para os anos 90. Rio de Janeiro: Editora da FIOCRUZ, 1996.

COSTA NETO, M.M; AZEVEDO, A.C. Proposta de classificação de hospitais e leitos. Rev Paulista Hospitais 1986;34(1/2/3):33-39.

COTTA,R.M.M., COTta Filho,J.S., MUNiZ,J.N. e MENDES, F. F. A Crise do SUS e a fuga para o Mercado. Ciência e Saúde Coletiva 3(1):94-105, 1998.

COVELLO, R. J. Gestão da qualidade nas instituições de saúde: como e porque implementar, SaudeBusiness, 2003.

COYLE, J.; BARDI, E. J. \& LANGLEY JR, C. J. The Management of Business Logistics. Minneapolis/St.Paul: West Publishing Company, 1996.

CRESWEL, J.V. Research Design: Qualitative and Quantitative Approches. Beverly Hills, CA. Sage Publications, 1994.

FERreirA, A. B. H. Novo Dicionário da Língua Portuguesa, $2^{\mathrm{a}}$ ed. Rio de Janeiro: ed. Nova Fronteira. 1986. 
FERREIRA, J. H. G. Alianças Estratégicas em Hospitais Privados: estudo de caso com oito hospitais. [Tese Doutorado]. São Paulo: Faculdade de Saúde Pública da USP, 2000.

FIGUEIREDO, P., ARKADER, R. Da Distribuição Física ao Supply Chain Management: o Pensamento, o Ensino e as Necessidades de Capacitação em Logística COPPEAD, UFRJ, 2000.

FIGUEIREDO, K. F.; FLEURY, P. F.; WANKE, P. Logística e gerenciamento da cadeia de suprimentos: planejamento do fluxo de produtos e dos recursos. São Paulo: Atlas, 2003.

FITZSIMMONS, J. A. e FITZSIMMONS, M. J. Administração de Serviços Operações, Estratégia e Tecnologia de Informação. Porto Alegre: Bookman, 2000.

FLEISCHMANN, M., H. R. Krikke, R. Dekker e S. D. P. Flapper, $\boldsymbol{A}$ Characterisation of Logistics Networks for product Recovery", OMEGA, The International Journal of Management Science, 28-6, 2000, 653-666.

FLEURY, P. F., WANKE, P., FIGUEIREDO, K. F. (organizadores). Logística Empresarial: Ed. Atlas São Paulo, 2000.

FLEURY, P. F., ARKADER, R. Da distribuição física ao Supply Chain. In: Logística Empresarial. Ed. Atlas São Paulo, 2000.

FLEURY, P.F. ; LAVALLE, C.R.S. Logística Empresarial - A Perspectiva Brasileira. São Paulo: Atlas, 2000.

FLEURY, Sonia El desafio de la gestión de las redes de políticas. IIG-BIBLOS. BIBLIOTECA DE IDEAS. SIN: 1560-5264. No. 12-13. 17/12/2002.

FOCAULT, M. Microfísica do Poder. 10ª edição. Rio de Janeiro: Ed. Graal, 1992.

GAZETA MERCANTIL (1996) Panorama setorial - Seguros. São Paulo. 
GIOVANELLA,L. e FLEURY,S. Universalidade da Atenção à Saúde: Acesso como Categoria de Análise. In: EIBENSCHUTZ,C. (1995) Política de Saúde: o Público e o Privado. Rio de Janeiro: Editora da FIOCRUZ, 1995.

GOMES, C.F.S.; RIBEIRO, P.C.C. Gestão da Cadeia de Suprimentos integrada à Tecnologia de Informação. São Paulo: Pioneira Thomson Learning, 2004.

GONÇALVES, E.L. - O hospital e a visão administrativa contemporânea. São Paulo, Pioneira, 1983.

GONÇALVES, E.L.; ACHÉ, C.A. O Hospital - empresa: do planejamento à conquista do mercado. RAE São Paulo: FGV, 1999, v. 39, nº 1.

GONÇALVES, A. A. Gestão da capacidade de atendimento em hospitais de câncer. 2004. 146 f. Tese (Doutorado em Engenharia de Produção) - Universidade Federal do Rio de Janeiro, Rio de Janeiro, 2004.

HAMZAGIC, M.; KAMIMURA, Q.P.; PHILIPI, A. Reverse logistics as a competetive, favourable toll for a sustainable environment. International Congress, UNINDU, 2005.

HFMO - HEALTHCARE FINANCIAL MANAGEMENT ORGANIZATION. HFMA's 2005 Supply Chain Benchmarking Survey. Disponivel em: www.fma.org/resouce/mckeenson_benchmark2005.pdf. Acesso em: setembro de 2008 .

HOLMBERG, S. A systems perspective on supply chain measurements. International Journal of Physical Distribution \& Logistics Management, v.30, n.10, p.847-868, 2000.

KAHN, A E. Indroduction: The Rationale of Regulation and the Propor Role of Economics. In: The Economics of Regulation. Principles and Institutions. Vol. I. Cambridge, London: MIT Press; 1988. 
KAMIMURA, Q.P. Microrregionalização: Uma proposta metodológica, organizacional e estratégica para os serviços de saúde de alta e média complexidades no litoral norte paulista. [Dissertação]. Taubaté: Universidade de Taubaté; 2004.

KAMIMURA, Q.P.; OLIVEIRA, E.A.Q.; MOLINA, V.L.I. Análise da estratégia de regionalização do setor de saúde: uma contribuição para o desenvolvimento local. In: CARNIELLO, M.F.; OLIVEIRA, E.A.Q.; SOUSA, C.M. Estudos de Gestão e Desenvolvimento Regional. São Paulo: Oficina de Livros, 2008.

KATO, J. M. Avaliação de Desempenho de Sistemas Logísticos Através do Seis Sigma e Balanced Scorecard. Revista FAE. Vol. 6, n. 2, p. 113-124, 2003.

KUMAR, A. OZDAMAR L. Procurement performance measurement system in the health care industry. International Journal of Health Care Quality Assurance, v. 18, n. 2, p. 152- 166. 2001.

LABRA, M.E. Sistemas de Saúde: Continuidades e Mudanças. Rio de Janeiro, Editora da FIOCRUZ/HUCITEC, 1995.

LABRA, M. E. Política e Saúde no Chile e no Brasil. Contribuições para uma comparação. Ciência e Saúde Coletiva. Volume 6, número 002. ASSOCIAÇÃO BRASILEIRA EM SAÚDE COLETIVA. Rio de Janeiro, 2001.

LAKATOS, E. M.; MARCONI, M. A. Técnicas de pesquisa. São Paulo: Atlas, 2002.

LAMBERT, D.M.; COOPER, M. C.; PAGH, J.D. Supply chain management: Implementation issues and research opportunities. The International Journal of Logistics Management, Ponte Vedra Beach, v. 9, n. 2; 1998.

LAMBERT, D.M.; STOCK, J.R.; VANTINE, J.G. Administração estratégica da logística. São Paulo: Vantine Consultoria, 1999. 
LAMBERT et al. The supply chain management processes. The International Journal of Logistics Management, Ponte Vedra Beach, v. 12, n. 2, p. 13-24, 2001.

LEITE, P. R. Logística Reversa: meio ambiente e competitividade. São Paulo: Prentice Hall, 2003.

LISBOA, T.C.L. Breve Histórico dos Hospitais. Gestão de Saúde em Debate. Notícias Hospitalares, ano 4, n 37, jun/jul, 2002.

LORENZI, N. M.; RILEY, R. T. Health Informatics and organizational change. In: BALL, M. J. et al. (ed.) Health care information management systems: a pratical guide. New York: Spring Verlarg, 1995, p. 175-192.

LUSSARI, W. R. Gestão Hospitalar: Mudando pela educação continuada. São Paulo: Arte\&Ciência, 2003.

LUZ, M.T. As Instituições Médicas no Brasil. Rio de Janeiro, Editora Graal, 1979.

MALIK, A. M. Pesquisa em, sobre e para os serviços de saúde: comentários em relação à pesquisa sobre serviços de saúde no Brasil. Cad. Saúde Pública, 2004, vol.20 suppl. 2, p.161-163.

MARRIOTT JR., J. W. in ALBRECHT, K. Revolução nos Serviços: como empresas podem revolucionar a maneira de tratar seus clientes. São Paulo: Pioneira Thompson Learning, 2002.

MAXIMIANO, A.C.A. Teoria Geral da Administração: da revolução urbana à revolução digital. $4^{\mathrm{a}}$. Edição. São Paulo: Atlas, 2004.

MAZZOTTI, A. J.; GEWANDSZNAJDER, F. O método nas ciências naturais e sociais: pesquisa quantitativa e qualitativa. 2. ed. São Paulo: Pioneira, 1999.

MEDICE, A. O Setor Privado Prestador de Serviços de Saúde no Brasil: Dimensão, Estrutura e Funcionamento. Relatórios Técnicos $n^{\circ} 2 / 90$. Rio de Janeiro: ENCE/IBGE; 1990. 
MENDES, E.V., 1993. As políticas de saúde no Brasil nos anos 80: a conformação da reforma sanitária e a construção da hegemonia do projeto neoliberal. In: Distrito Sanitário: o processo social de mudança das práticas sanitárias do SUS (MENDES, E.V. org), São Paulo/Rio de Janeiro: Hucitec/ Abrasco.

MENDES, E.V. Uma Agenda para a Saúde. São Paulo: Editora HUCITEC, 1996.

MENDES, E.V. - Os sistemas de serviços de saúde: o que os gestores deveriam saber sobre essas organizações complexas. Fortaleza, Escola de Saúde Pública do Ceará, 2002.

MENDES, E.V. - Os sistemas de serviços de saúde: o que os gestores deveriam saber sobre essas organizações complexas. Fortaleza, Escola de Saúde Pública do Ceará, 2002.

MERCADANTE, O.A. Evolução das Políticas e do Sistema de Saúde no Brasil. MINAYO, M.C.S. O Desafio do Conhecimento: pesquisa qualitativa em saúde. 7 . Edição. São Paulo: Hucitec; Rio de Janeiro: Abrasco, 2000.

MINISTÉRIO DA SAUDE. Reforma do Sistema da Atenção Hospitalar Brasileira. Brasília, 2004.

MIRSHAWKA, V. Hospital fui bem atendido: a hora e a vez do Brasil. São Paulo: Makron Books, 1994.

MOLINA, V. L. I. Negociações pelo “Alto": um estudo sobre a formulação das Políticas de Saúde em São José dos Campos, de 1980 a 1996. 1998. Tese de Doutorado. Faculdade de Ciências e Letras, Universidade Estadual Paulista, Araraquara.

MONTEIRO FILHO, A. J. Estudo do Aspecto Físico da Unidade de Internação Geral. Tese de Doutorado. Faculdade de Saúde Pública, Universidade de São Paulo, São Paulo, 1972. 
MOURA, R. [et al.]. Atualidades na logística. São Paulo: IMAM, 2003.

NOVAES, H.M.; MOTTA, P.R. Manual protótipo de educação em administração hospitalar. Rio de Janeiro. Fundação Kellogg, 1996.

NOVAES, A. G. Logística e gerenciamento da cadeia de distribuição. Rio de Janeiro: Elsevier, 2007.

OCDE. Private Health Insurance in OECD Countries. The OECD Health Project, 2004.

OCKÉ, R.C.O (1995) O Setor Privado em Saúde no Brasil: os Limites da Autonomia. [Tese de Mestrado]. Instituto de Medicina Social/UERJ.

OLIVEIRA, S.C. Avaliação da qualidade dos serviços de saúde em um estudo de caso. Dissertação - Universidade Estadual do Rio de Janeiro, Rio de Janeiro, 1996.

OHNO, T. O Sistema Toyota de Produção: além da produção em larga escala. Porto Alegre: Artes Médicas, 1997.

OPAS, 1990

OPAS. ORGANIZAÇÃO PAN-AMERICANA DA SAÚDE. Proposta da OMS para Revisão da lista modelo de medicamentos essenciais da OMS: discussão do processo de participação dos estados membros. Portaria CD 43/5, Washington, 27 de agosto de 2001 .

OPAS. ORGANIZAÇÃO PAN-AMERICANA DA SAÚDE. A transformação da gestão de hospitais na América Latina e Caribe. Brasília: OPAS/MS, 2004.

PAHO. The Public Private Mix in National Health Systems and the Role of Ministries of Health. Reprint Series n. 3. Documentation and Information center, Health Policies Development Program. Washington, DC, 1992.

PIRES, S.R.I. Gestão da Cadeia de Suprimentos: conceitos, estratégias, prática e casos. 1 ${ }^{\text {a }}$. Edição. São Paulo: Atlas, 2004. 
POIRIER, C.; REITER, S. Otimizando sua rede de negócios. Tradução: Mauro Pinheiro. São Paulo: Futura, 1997. Tradução de: Supply chain optimization.

REY, M. F. Indicadores de Desempenho Logístico. Revista Logman. Vol. 30, n.10, p. 18-23, 1999.

ROEMER, M. Perspectiva Mundial de los Sistemas de Salud. México, Siglo Veinteuno Editores, 1980.

RODRIGUEZ, C. M. T. Avaliação de desempenho de sistemas logísticos. Florianópolis: Departamento de Engenharia da Produção - UFSC, 2005.

SCLIAR, M. Do Mágico ao Social: A Trajetória da Saúde Pública. I\&PM, 1987.

SHORTELL, S.; KALUZNY. Healthcare management: organization, design and behavior. New York: Thomson Learning, 2000.

SELLTIZ, C. et al. Métodos de pesquisa nas relações sociais. São Paulo: Edusp, 1975.

SIMCHI-LEVI, David; KAMINSKI, Philip; SIMCHI-LEVI, Edith. Cadeia de suprimentos: projeto e gestão. Porto Alegre: Bookman, 2003.

SLACK, Nigel et al. Administração da produção. São Paulo: Atlas, 1996.

TERRIS, M. Tendencias y perspectivas de los tres sistemas mundiales de atención médica. Foro Mundial de la Salud, 1 (1,2): 93-103, 1980.

TONELlO, S.; MARTINHO, E. Crise nos hospitais ou crise de liderança? Notícias Hospitalares, $n^{\circ} 41,2003$.

TRIVIÑOS, A. N. S. Introdução à pesquisa em Ciências Sociais. A pesquisa qualitativa em educação. São Paulo, Atlas, 1990.

TUBINO, D. F. Sistemas de Produção: a produtividade no chão de fábrica. Porto Alegre: Bookman, 1999. 
UGÁ, M. A. Propostas de Reforma do Setor Saúde nos Marcos do Ajuste Macroeconômico. [Tese de Doutorado]. Rio de Janeiro: Instituto de Medicina Social, UERJ; 1997.

UGÁ, M. A.; SANTOS, I. S.; PORTO, S. M. O mix público-privado no Sistema de Saúde Brasileiro: financiamento, oferta e utilização de serviços de saúde. Ciência e Saúde Coletiva, vol. 13 n5, Rio de Janeiro, Set/Out., 2008. Disponível em: www.scielosp.org. Acesso em novembro de 2008.

VECINA NETO, G.; REINHARDT FILHO, W. Gestão de Recursos Materiais e Medicamentos. São Paulo, Coleção Saúde e Cidadania. Instituto para o Desenvolvimento da Saúde: Núcleo de Assistência Médico-Hospitalar:Fundação Itaú Social, 2002.

VECINA NETO, G.; MALIK, A.M. Tendências na assistência hospitalar. Revista Caderno de Saúde Col. 2007; 12(4):825-839.

VIANNA, S. M., PIOLA, S., MEDICI, A C. e CAMARGO, S. (1987) O Impacto da Crise Econômica nos Serviços de Saúde: o caso do Brasil, vol. II., Brasília, OPS, 1987.

YIN, R. Estudo de caso: planejamento e métodos. 2.ed. Porto Alegre: Bookman, 2001.

WANKE, P. Gestão de Estoques na Cadeia de Suprimentos. São Paulo: Atlas, 2003.

WOMAK, J. F.; JONES, D. Lean Thinking banish waste and create wealth in your corporatin, New York, N.Y.: Simon \& Schuster, (1996).

WOMAK, J. P.; JONES, D. T. Mentalidade Enxuta. Rio de Janeiro: Campus, 1998. . WOOD J. R, T.; ZUFFO, P. K. Supply chain management. Revista de Administração de Empresas, São Paulo, v. 38, n. 3, p. 55-63, jul./set. 1998.

ZUCCHI, P. Seguro saúde no Brasil: tendências de consumo. Tese Doutorado. Faculdade de Saúde Pública, Universidade de São Paulo, São Paulo, 2000. 
BIBLIOGRAFIA CONSULTADA:

BITTAR, O.J.N.V. Problemas Culturais na Crise da Saúde. In: Gazeta Mercantil, São Paulo, 13 de abril de 2004.

BNDES. Hospitais filantrópicos no Brasil. Rio de Janeiro, BNDES, 2002.

CAStro, M. Prática de Pesquisa. São Paulo: McGraw Hill do Brasil, 1997.

COPACINO, W. C. Supply Chain Management - The Basics and Beyond APICS Séries on Resource Management USA: The Lucie Press, 1997.

JOHNSTON, R.; CLARK, G. Administração de Operações de Serviço. São Paulo: Atlas, 2002.

MENDES, E.V. Uma Agenda para a Saúde. São Paulo: Editora HUCITEC, 1996.

MINISTÉRIO DA SAUDE. Reforma do Sistema da Atenção Hospitalar Brasileira. Brasília, 2004.

PAIXÃO, W. Páginas de história da enfermagem. 2.ed. Rio de Janeiro: Buccini, 1960.

STANK, T.; CRUM, M.; ARANGO, M. Benefits of interfirm coordination in food industry supply chains. Journal of Business Logistics, Birmingham, v. 20, $\mathrm{n}^{\circ} .2, \mathrm{p}$. 21-41, 1999.

THE GLOBAL LOGISTICS RESEARCH TEAM AT MICHIGAN STATE. UNIVERSITY. World Class Logistics: the challenge of managing continuous change. Ilionois: Oak Brook, Council of Logistics Management,1995. 


\section{ANEXOS}

- Anexo A - Organograma dos Hospitais

- Anexo B - Comitês de Ética em Pesquisa

- Anexo C - Consentimento Livre e Esclarecido 
ANEXO A - Organograma dos Hospitais 
Anexo A 1 - Organograma

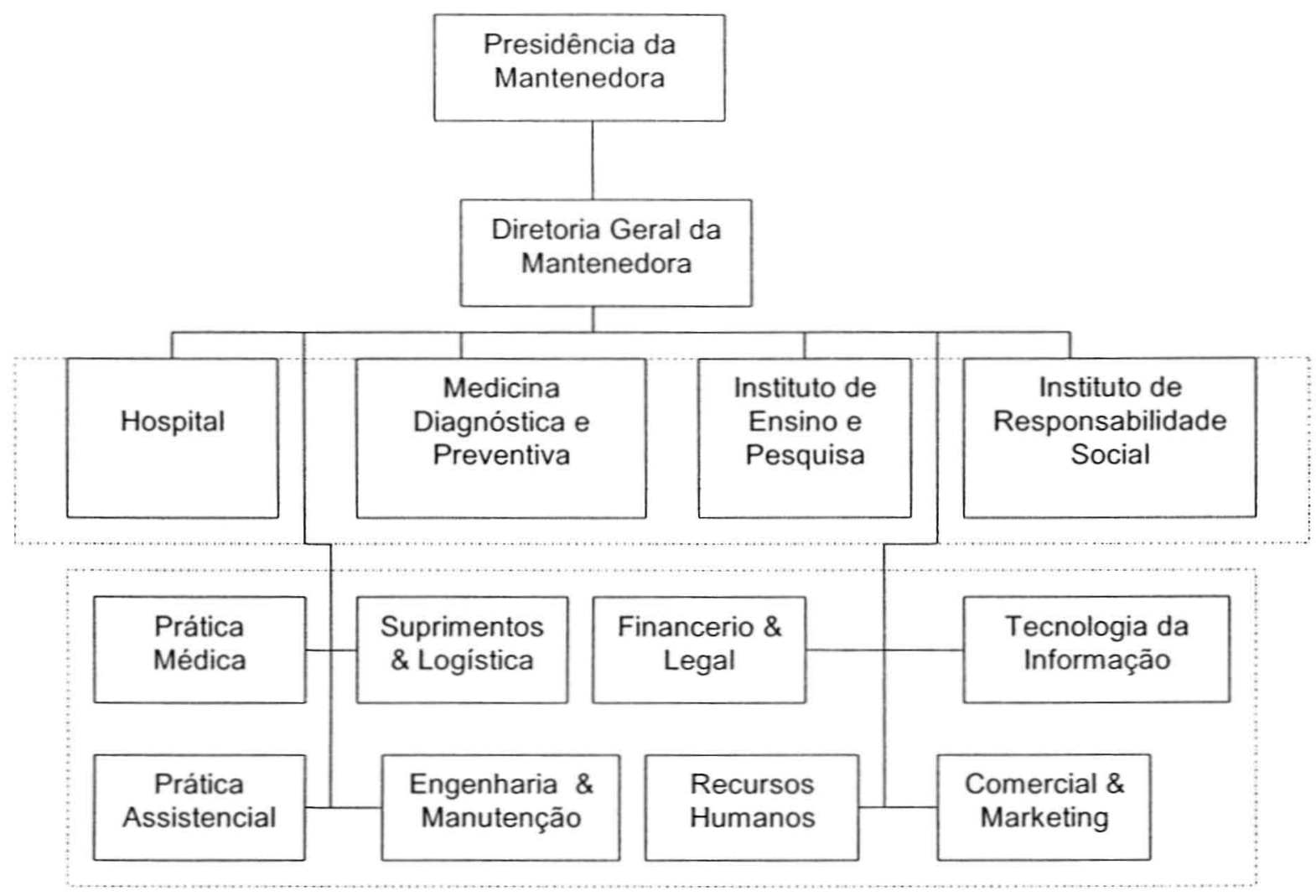




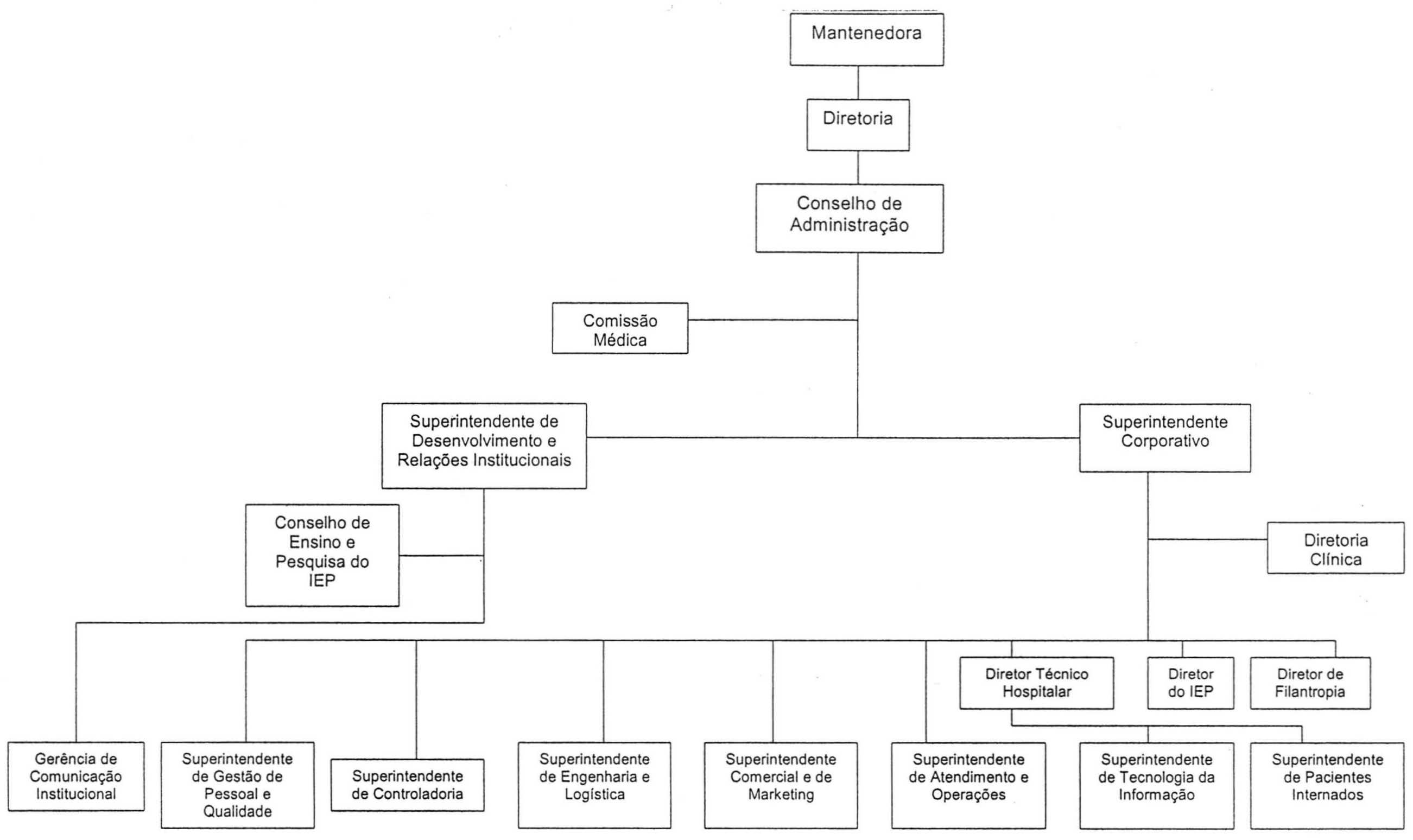




\section{Anexo A3 - ORGANOGRAMA GERAL}

Dir.Presidente / Vice Presidentes (2) / Dir. Patrimônio / Dir. Financeiro / Dir. Médicos (3) / Dir. Clinico / Demais Diretores (5).

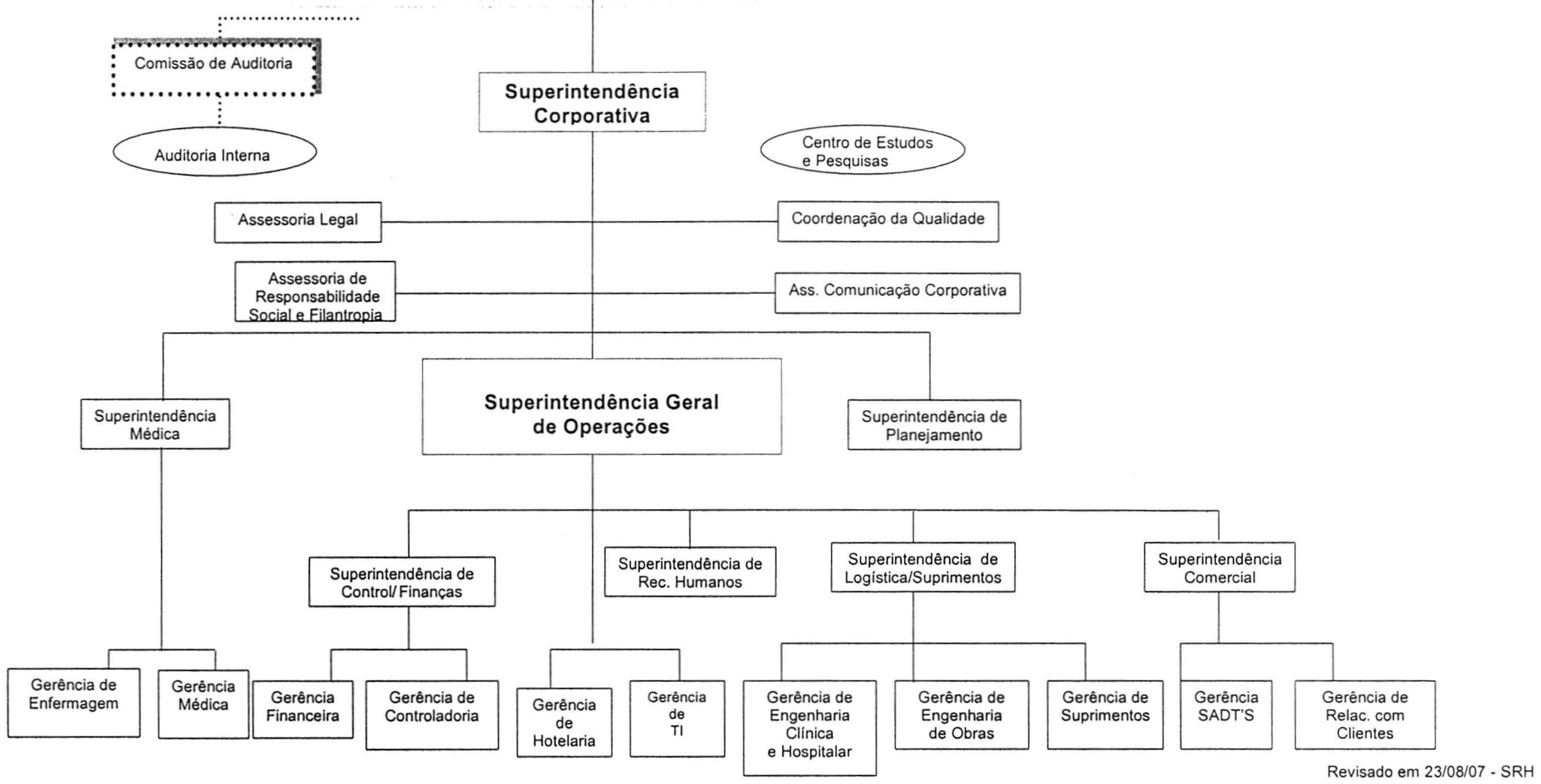


Anexo

A. 4

Organograma Institucional

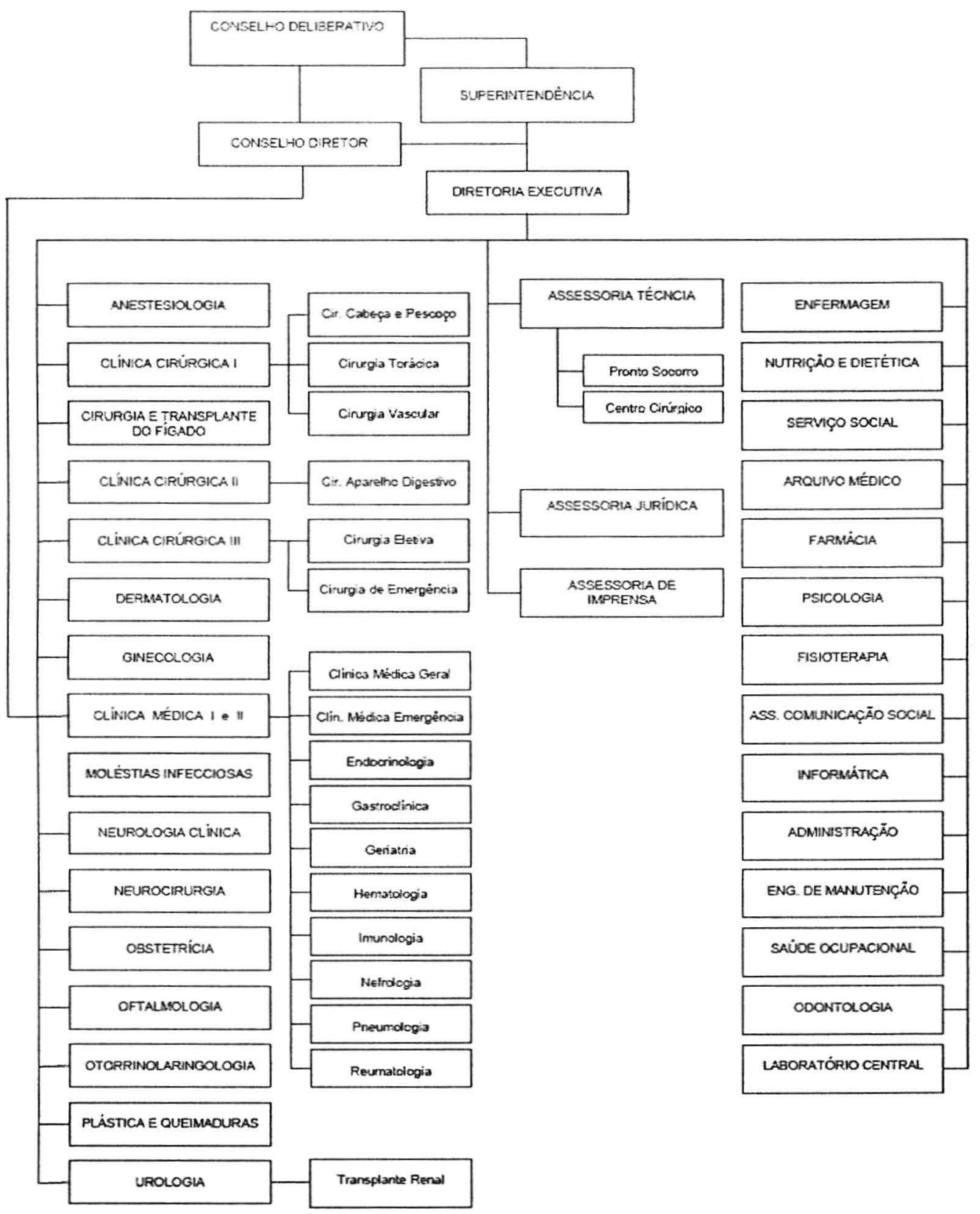


Anexo A.5 - Organograma Institucional

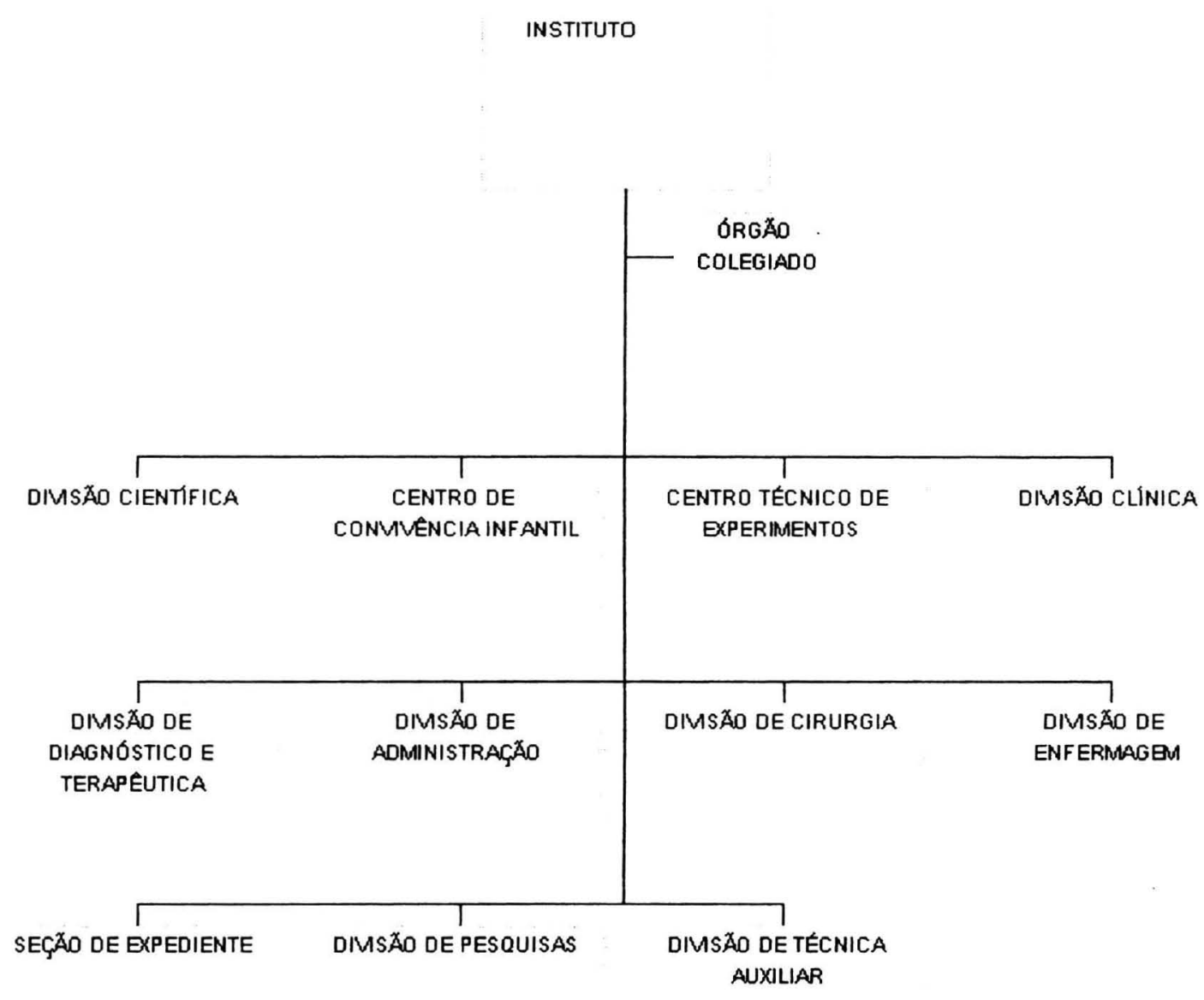


ANEXO B - Comitês de Ética em Pesquisa 
Protocolo

Projeto de Pesquisa

Pesquisador(a)
1793

LOGÍSTICA EM SERVIÇO DE SAÚDE

Quésia Postigo Kamimura

24 de OUTUBRO de 2008.

Prezado(a) Orientador(a),

O Comitê de Ética em Pesquisa da Faculdade de Saúde Pública da Universidade de São Paulo - COEP analisou, em sua 9. ${ }^{2} / 08$ Sessão ORDINÁRIA, realizada em 17/10/2008, de acordo com os requisitos da Resolução CNS/196/96 e suas complementares, o protocolo de pesquisa acima intitulada e o considerou APROVADO.

Cabe lembrar que conforme Resolução CNS/196/96 são deveres do (a) pesquisador (a):

1. Comunicar, de imediato, qualquer alteração no projeto e aguardar manifestação deste CEP (Comitê de Ética em Pesquisa), para dar continuidade à pesquisa;

2. Manter sob sua guarda e em local seguro, pelo prazo de 5 (cinco) anos, os dados da pesquisa, contendo fichas individuais e todos os demais documentos recomendados pelo CEP, no caso eventual auditoria;

3. Comunicar, formalmente a este Comitê, quando do encerramento deste projeto;

4. Elaborar e apresentar relatórios parciais e final;

5. Justificar, perante o CEP, interrupção do projeto ou a não publicação dos resultados.

Atenciosamente,

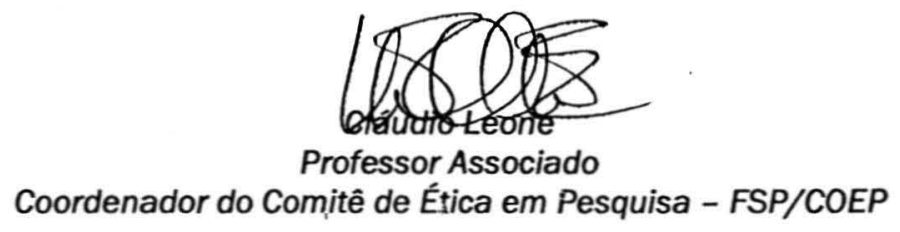

IIm. ${ }^{a} \mathrm{Sr} .^{\mathrm{a}}$

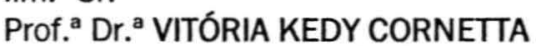

DEPARTAMENTO DE PRÁTICA DE SAÚDE PÚBLICA

FACULDADE DE SAÚDE PÚBLICA

UNIVERSIDADE DE SÃO PAULO

Av. Dr. Arnaldo, 715 - Assessoria Acadêmica - CEP: 01246-904 - São Paulo - SP

Telefones: (55-11) 3061-7779/7742 e-mail: coep@fsp.usp.br site www.fsp.usp.br 
São Paulo, 05 de março de 2008.

Ilma. Dra. Quésia Postigo Kamimura

Pesquisadora Principal

Registro CEPesq: HSL2008/08

Pesquisa: "Logística em Serviços de Saúde".

Prezada Pesquisadora,

O Comitê de Ética em Pesquisa do Hospital Sírio-Libanês relatou o estudo acima citado não tendo objeção nenhuma para sua realização. Porém, fica ainda pendente a resposta da Direção Técnica Hospitalar que é quem dará a aprovação final.

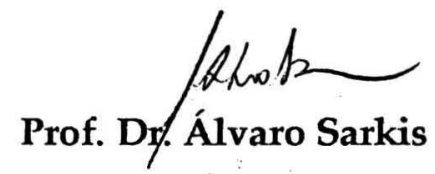

Presidente do Comitê de Ética em Pesquisa - CEPesq

Hospital Sírio-Libanês 
São Paulo, 05 de maio de 2008.

\section{Sra. Qúesia Postigo Kamimura}

Pesquisadora Principal

\section{Referente : Protocolo Pesquisa HSL2008/08 - Quésia Postigo Kaminura}

Pesquisa: "Logística em Serviços de Saúde".

Prezada senhora,

A Direção Técnica Hospitalar aprova a realização do estudo acima citado em nossa Instituição.

Lembramos que este projeto deverá apresentar relatório semestral para acompanhamento do CEPesq - Comitê de Ética em Pesquisa bem como para Direção Técnica Hospitalar.

Atenciosamente,

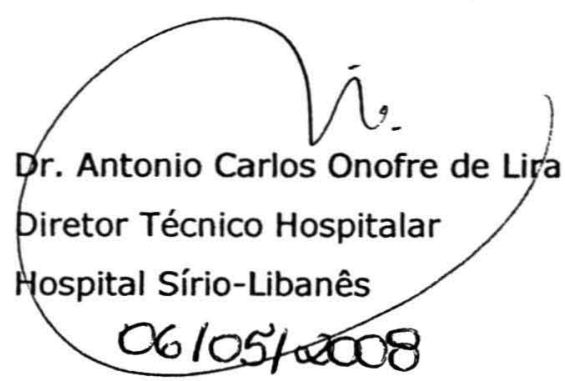




\section{APROVAÇÃO}

A Comissão de Ética para Análise de Projetos de Pesquisa - CAPPesq da Diretoria Clínica do Hospital das Clínicas e da Faculdade de Medicina da Universidade de São Paulo, em sessão de 02/04/2008, APROVOU o Protocolo de Pesquisa $n^{\circ}$ 0114/08, intitulado: "LOGÍstICA EM SERVIÇOS DE SAÚDE" apresentado pela Superintendência, inclusive o Termo de Consentimento Livre e Esclarecido.

Cabe ao pesquisador elaborar e apresentar à CAPPesq, os relatórios parciais e final sobre a pesquisa (Resolução do Conselho Nacional de Saúde $n^{\circ} 196$, de 10/10/1996, inciso IX.2, letra "c").

Pesquisador (a) Responsável: Dr. Haino Burmester Pesquisador (a) Executante: Quésia Postigo Kamimura Orientador: Prof.Dr. Olimpio José Nogueira Viana Bittar

CAPPesq, 04 de Abril de 2008

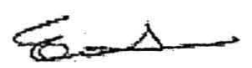

Prof. Dr. Eduardo Massad Presidente da Comissão de Ética para Análise de

Projetos de Pesquisa

Comissão de Ética para Análise de Projetos de Pesquisa do HCFMUSP e da FMUSP Diretoria Clínica do Hospital das Clínicas da Faculdade de Medicina da Universidade de São Paulo Rua Ovídio Pires de Campos, 255, $5^{\circ}$ andar - CEP 05403010 - Săo Paulo - SP Fone: 0113069 6442 Fax: 01130696492 e-mail: cappesq@hcnet.usp.br/ secretariacappesq2@hcnet.usp.br 


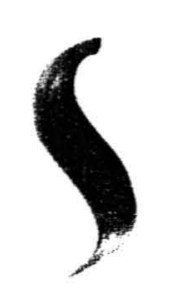

SAMARITANO

sion patiog

São Paulo, 26 de fevereiro de 2008.

$\grave{A}$

Sra. Quésia P. Kamimura

Ref.: PROJETO DE PESQUISA "Logística em Serviços de Saúde".

Prezada Senhora,

Em atenção a sua solicitação para o desenvolvimento do projeto em referência, junto a esta Instituição, o Comitê de Ética em Pesquisa, por intermédio de seu Coordenador aprova a realização da pesquisa nos termos e métodos previstos, desde que observadas a seguinte determinação:

- Manter o Comitê informado sobre o trabalho realizado, encaminhandoIhe relatório de acompanhamento e, ao final, o resultado da pesquisa inserido no contexto do projeto.

Atenciosamente,

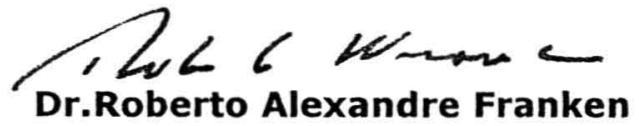

Coordenador do Comitê de Ética em Pesquisa

Sociedade Hospital Samaritano 
São Paulo, 02 de setembro de 2008

\section{Ref. CEP/Einstein No 08/953}

CAAE - 0179.0.028.207-08

Título: Logística em Serviços de Saúde

Investigador Principal: Quésia Postigo Kamimura

Ilma. Sra.

Quésia Postigo Kamimura

O Comitê de Ética em Pesquisa do Hospital Israelita Albert Einstein analisou e aprovou o projeto de pesquisa supracitado, bem como o Termo de Consentimento Livre e Esclarecido, do projeto de pesquisa supracitado.

Aproveitamos a oportunidade para orientar o pesquisador sobre os seguintes itens:

- O sujeito da pesquisa tem a liberdade de recusar-se a participar ou de retirar seu consentimento em qualquer fase da pesquisa, sem penalização alguma e sem prejuízo ao seu cuidado (Res. CNS 196/96 - Item IV.1.f) e deve receber uma cópia do Termo de Consentimento Livre Esclarecido, na íntegra, por ele assinado (Item IV.2d).

- O Pesquisador deve desenvolver a pesquisa conforme delineada no protocolo aprovado e descontinuar o estudo somente após análise das razões da descontinuidade pelo CEP que o aprovou (Res.CNS 196 Item III. 3z), aguardando seu parecer, exceto quando perceber risco ou dano não previsto

ao sujeito participante ou quando constatar a superioridade de regime oferecido a um dos grupos da pesquisa (Item V.3) que requeiram ação imediata. 


\section{ALBERT EINSTEIN \\ ENSINO E PESQUISA}

- O CEP deve ser informado de todos os efeitos adversos ou fatos relevantes que alterem o curso normal do estudo (Res. CNS Item V.4). É papel do pesquisador assegurar medidas imediatas adequadas frente a evento adverso grave ocorrido

(mesmo que tenha sido em outro centro) e enviar notificação ao CEP e à Agência Nacional de Vigilância Sanitária - ANVISA - junto com seu posicionamento.

- Eventuais modificações ou emendas ao protocolo devem ser apresentadas ao CEP de forma clara e sucinta, identificando a parte do protocolo a ser modificada e suas justificativas. Em caso de projetos do Grupo I ou II apresentados anteriormente à ANVISA, o pesquisador ou patrocinador deve enviá-las também à mesma, junto com o parecer aprovatório do CEP, para serem juntadas ao protocolo inicial (Res. 251/97. item III.2.e).

- Relatórios parciais e finais devem ser apresentados ao CEP, inicialmente em Março de 2009.

Atenciosamente,

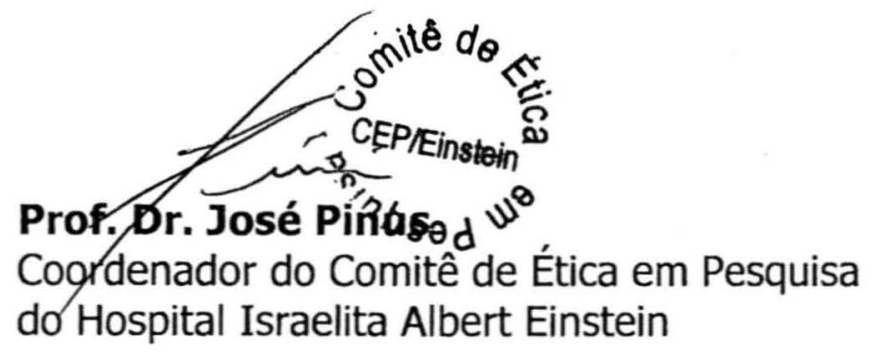



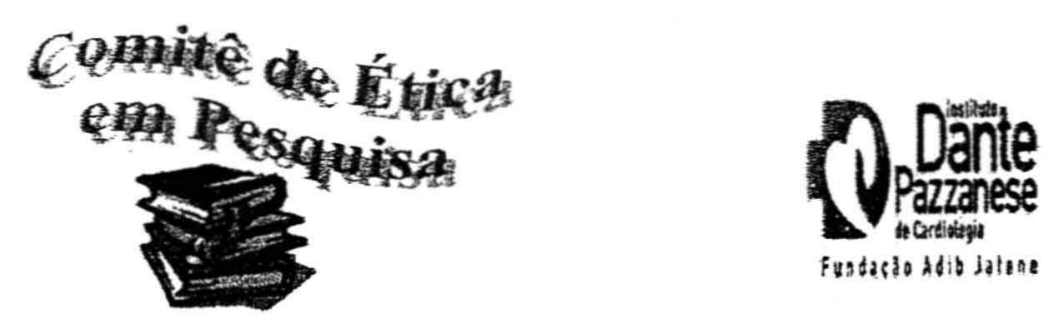

DATA DA ENTRADA: 01 de Janeiro de 2008.

DATA DA AVALIAÇÃO: 12 de Fevereiro de 2008.

N' DO PROTOCOLO NO CEP: 3613

(este $\mathrm{n}^{\circ}$ deverá citar nas correspondências referentes a este projeto)

Pesquisador: Dra.Quesia Postigo Kamimura

Area de Especializaçäo: Saúde Pública

$N^{\circ}$ de Suleltos no Centro: 1

Ne de Sujeltos no Brasil: 6

Ne de Sujeitos Total: 6

Unitermos: Logística, suppły chain; serviços de saúde

Vinculada: Faculdade de Saúde Pública da Universidade de Săo Paulo

Projeto de Pesquisa: "LOGISTICA EM SERVIÇOS DE SAÚDE".

Consideraçöes/Comentários: O objetivo deste estudo será analisar o sistema logístico das organizaçōes de saúde, especificamente hospitais, públicos e privados. Conhecer a arquitetura e os modelos funcionais logisticos dos hospitais, públicos e privados, e, respectiva inserçāo na cadeia de organizaçōes; conhecer os indicadores logísficos utilizados nas organizaçōes a serem pesquisadas.

Ao se proceder à andlise ao projeto em questão, considera-se que:

a) O projeto preenche os requisitos fundamentais das resoluções CNS 196/96, $251 / 97$ e 292199, sobre as Diretrizes e Normas Regulamentadoras de Pesquisa Envolvendo Seres Humanos, do Conselho Nacional de Saúde $t$ Conselho Nacional de Ética em Pesquisa $/$ Agência Nacional de Vigilância Sanitária e as Boas Práticas de Pesquisa Clínica do ICH-GCP.

b) O Comitê de Ética em Pesquisa avaliou o Protocolo de Estudo e o Termo de Consentimento Livre e Esclarecido. 


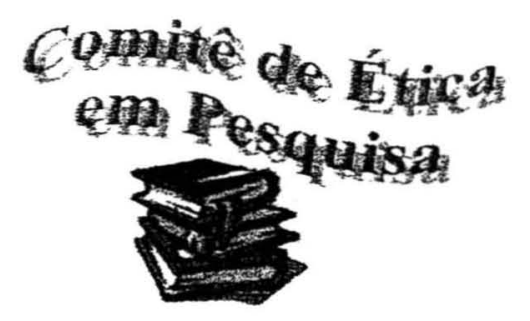

c) O Comitê de Ética em Pesquisa segue os preceitos das resoluções CNS196/96, 251/97 e 292/99, sobre as Diretrizes e Normas Regulamentadoras de Pesquisa Envolvendo Seres Humanos, do Conselho Nacional de Saúde I Conselho Nacional de Ética em Pesquisa / Agência Nacional de Vigilância Sanitária e as Boas Práticas de Pesquisa Clínica do ICH-GCP.

Diante do exposto, 0 Comite de Ética em Pesquisa, manifesta-se pela:

- Protocolo de Estudo "Logistica em Serviços de Saúde" - Aprovado

- Termo de Consentimento Livre e Esclarecido - Aprovado

- Declaração de Orçamento Detalhado - Aprovado

- Questionário ou roteiro de entrevista-Aprovado

- Termo de Responsabilidade do pesquisador - Entregue

- Cronograma atualizado - Entregue

- Folha de Rosto-Entregue

o Comite de Ética em Pesquisa, solicita que:

a) Informar imediatamente relatório sobre qualquer evento adverso ocorrido

b) Comunicar qualquer alteraçăo no projeto e no TCLE

Situaçaxo: Protocolo Avaliado e Aprovado em reuniåo ordinária no dia 12 de Fevereiro de 2008.

São Pauło, 12 de Fevereiro de 2008.

Fodrately

Pedr Silvo Farsty

Coordinarior CEP

CRM 55073

AV.DRDANTE PAZZANESE,S00-PRÉDIO --BRIRAPUERA-04012-180-S.P Telefax (11) $5083-6040$ copidpo(g)terra com.br 
ANEXO C - Termo de Consentimento Livre e Esclarecido 


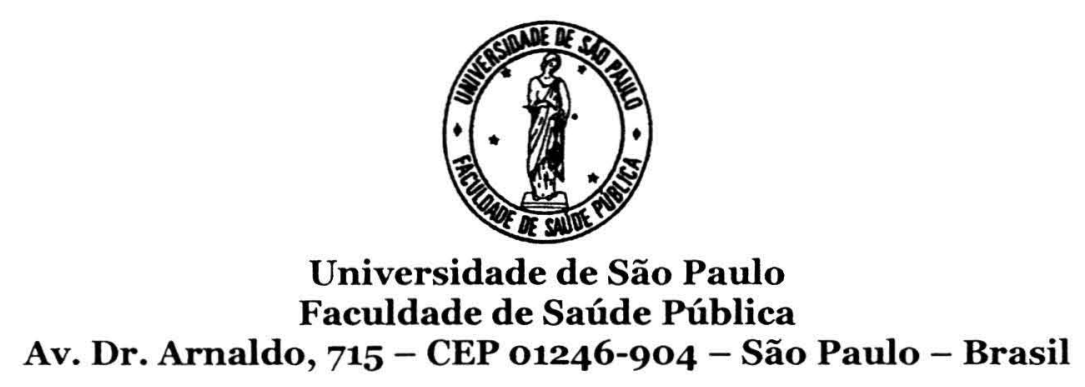

TERMO DE CONSENTIMENTO LIVRE E ESCLARECIDO

\section{I - DADOS SOBRE A PESQUISA}

1. Título do Protocolo de Pesquisa:.Logística em Serviços de Saúde

Pesquisador: Quésia Postigo Kamimura

Documento de Identidade $N^{0}: 16.157 .832$ Sexo: ( ) M $\quad(x) F$

Cargo/Função: Doutoranda

Departamento de Prática de Saúde Pública da Faculdade de Saúde Pública da Universidade de São Paulo.

2. Duração da Pesquisa: 4 (quatro) meses.

\section{II - REGISTRO DAS EXPLICAÇÕES DO PESQUISADOR AO SUJEITO DA PESQUISA OU} SEU REPRESENTANTE LEGAL SOBRE A PESQUISA, CONSIGNANDO:

A pesquisa proposta é de natureza acadêmica e tem como objetivo apresentar uma análise da evolução do sistema logístico no ambiente hospitalar e visa expandir os conhecimentos sobre um assunto recente e em desenvolvimento no mundo atual das organizações.

Para tanto será necessária a coleta de informações relacionadas ao sistema logístico das organizações hospitalares que serão pesquisadas por meio de documentos, entrevista semiestruturada junto a um representante da gestão hospitalar e visita de campo.

O participante é livre para expressar suas idéias e poderá fazer qualquer questionamento acerca do estudo e sobre sua participação nele, se tiver alguma dúvida procuraremos esclarecê-la em qualquer fase da pesquisa. A participação é voluntária e tem o direito de sair da pesquisa em qualquer etapa e em momento algum isto lhe trará prejuízos.

III - ESCLARECIMENTOS DADOS PELO PESQUISADOR SOBRE GARANTIAS DO SUJEITO DA PESQUISA

Os participantes da pesquisa terão direito de acesso, a qualquer tempo, às informações sobre procedimentos, riscos e benefícios relacionados à pesquisa, inclusive para dirimir eventuais dúvidas poderá entrar em contato com a pesquisadora por meio dos telefones 12-3832 5794 ou 12-97143988 e dos e-mails: qkamimura@uol.com.br ou qkamimura@usp.br e com o 
Comitê de Ética em Pesquisa da Faculdade de Saúde Pública da Universidade de São Paulo, telefone 1130617779 .

Fica claro que os participantes da pesquisa ou seu representante legal, podem, a qualquer momento, retirar seu consentimento e de deixar de participar do estudo e fica ciente que todo trabalho realizado torna-se informação confidencial, guardada por força de sigilo profissional.

\section{IV - CONSENTIMENTO PÓS-ESCLARECIDO}

Declaro que, após convenientemente esclarecido pelo pesquisador e ter entendido o que me foi explicado, consinto em participar do presente Protocolo de Pesquisa.

São Paulo, de de

Assinatura do sujeito de pesquisa ou responsável legal

Assinatura do pesquisador (carimbo ou nome legivel) 


\section{1. \\ Universidade de São Paulo \\ Faculdade de Saúde Pública \\ Av. Dr. Arnaldo, 715 - CEP o1246-904 - São Paulo - Brasil}

\section{TERMO DE CONSENTIMENTO LIVRE E ESCLARECIDO}

\section{I-DADOS SOBRE A PESQUISA}

3. Título do Protocolo de Pesquisa:.Logística em Serviços de Saúde

Pesquisador: Quésia Postigo Kamimura

Documento de Identidade $N^{0}: 16.157 .832$ Sexo: ( ) M $\quad(x) F$

Cargo/Função: Doutoranda

Departamento de Prática de Saúde Pública da Faculdade de Saúde Pública da Universidade de São Paulo.

4. Duração da Pesquisa: 4 (quatro) meses.

\section{II - REGISTRO DAS EXPLICAÇÕES DO PESQUISADOR AO SUJEITO DA PESQUISA OU} SEU REPRESENTANTE LEGAL SOBRE A PESQUISA, CONSIGNANDO:

A pesquisa proposta é de natureza acadêmica e tem como objetivo apresentar uma análise da evolução do sistema logístico no ambiente hospitalar e visa expandir os conhecimentos sobre um assunto recente e em desenvolvimento no mundo atual das organizações.

Para tanto será necessária a coleta de informações relacionadas ao sistema logístico das organizações hospitalares que serão pesquisadas por meio de documentos, entrevista semiestruturada junto a um representante da gestão hospitalar e visita de campo.

O participante é livre para expressar suas idéias e poderá fazer qualquer questionamento acerca do estudo e sobre sua participação nele, se tiver alguma dúvida procuraremos esclarecê-la em qualquer fase da pesquisa. A participação é voluntária e tem o direito de sair da pesquisa em qualquer etapa e em momento algum isto the trará prejuizos.

\section{III - ESCLARECIMENTOS DADOS PELO PESQUISADOR SOBRE GARANTIAS DO SUJEITO DA PESQUISA}

Os participantes da pesquisa terão direito de acesso, a qualquer tempo, às informações sobre procedimentos, riscos e benefícios relacionados à pesquisa, inclusive para dirimir eventuais dúvidas poderá entrar em contato com a pesquisadora por meio dos telefones 12-3832 5794 ou 12-97143988 e dos e-mails: qkamimura@uol.com.br ou qkamimura@usp.br e com o 
Comitê de Ética em Pesquisa do Instituto Dante Pazzanese de Cardiologia, telefone 115085 6040

Fica claro que os participantes da pesquisa ou seu representante legal, podem, a qualquer momento, retirar seu consentimento e de deixar de participar do estudo e fica ciente que todo trabalho realizado torna-se informação confidencial, guardada por força de sigilo profissional.

\section{IV - CONSENTIMENTO PÓS-ESCLARECIDO}

Declaro que, após convenientemente esclarecido pelo pesquisador e ter entendido o que me foi explicado, consinto em participar do presente Protocolo de Pesquisa.

São Paulo, de de 


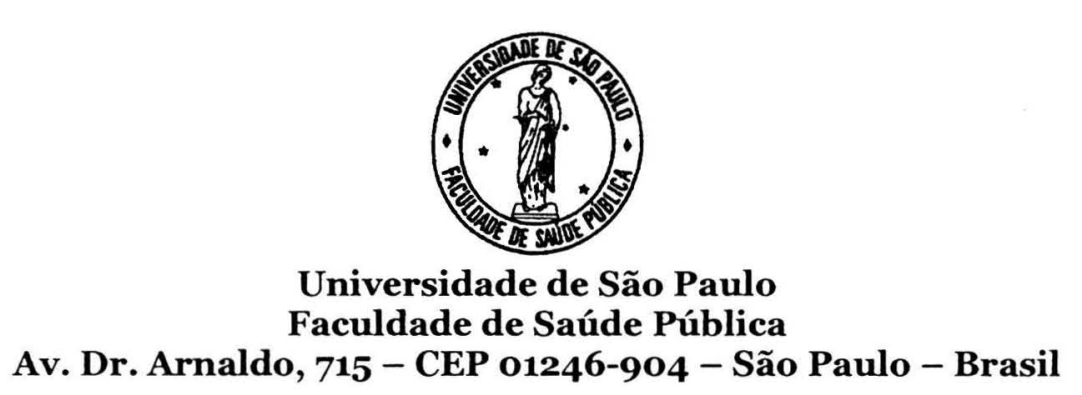

TERMO DE CONSENTIMENTO LIVRE E ESCLARECIDO

I - DADOS SOBRE A PESQUISA

1. Título do Protocolo de Pesquisa:.Logística em Serviços de Saúde Pesquisador: Quésia Postigo Kamimura

Documento de Identidade $N^{\circ}: 16.157 .832$ Sexo: ( ) M $\quad(x) F$

Cargo/Função: Doutoranda

Departamento de Prática de Saúde Pública da Faculdade de Saúde Pública da Universidade de São Paulo.

2. Duração da Pesquisa: 4 (quatro) meses.

\section{II - REGISTRO DAS EXPLICAÇÕES DO PESQUISADOR AO SUJEITO DA PESQUISA OU} SEU REPRESENTANTE LEGAL SOBRE A PESQUISA, CONSIGNANDO:

A pesquisa proposta é de natureza acadêmica e tem como objetivo apresentar uma análise da evolução do sistema logístico no ambiente hospitalar e visa expandir os conhecimentos sobre um assunto recente e em desenvolvimento no mundo atual das organizações.

Para tanto será necessária a coleta de informações relacionadas ao sistema logístico das organizações hospitalares que serão pesquisadas por meio de documentos, entrevista semiestruturada junto a um representante da gestão hospitalar e visita de campo.

O participante é livre para expressar suas idéias e poderá fazer qualquer questionamento acerca do estudo e sobre sua participação nele, se tiver alguma dúvida procuraremos esclarecê-la em qualquer fase da pesquisa. A participação é voluntária e tem o direito de sair da pesquisa em qualquer etapa e em momento algum isto lhe trará prejuízos.

III - ESCLARECIMENTOS DADOS PELO PESQUISADOR SOBRE GARANTIAS DO SUJEITO DA PESQUISA

Os participantes da pesquisa terão direito de acesso, a qualquer tempo, às informações sobre procedimentos, riscos e benefícios relacionados à pesquisa, inclusive para dirimir eventuais dúvidas poderá entrar em contato com a pesquisadora por meio dos telefones 12-3832 5794 ou 12-97143988 e dos e-mails: qkamimura@uol.com.br ou qkamimura@usp.br e com o 
Comitê de Ética em Pesquisa do Hospital das Clínicas da Faculdade de Medicina da Universidade de São Paulo, telefone 1130696442.

Fica claro que os participantes da pesquisa ou seu representante legal, podem, a qualquer momento, retirar seu consentimento e de deixar de participar do estudo e fica ciente que todo trabalho realizado torna-se informação confidencial, guardada por força de sigilo profissional.

\section{IV - CONSENTIMENTO PÓS-ESCLARECIDO}

Declaro que, após convenientemente esclarecido pelo pesquisador e ter entendido o que me foi explicado, consinto em participar do presente Protocolo de Pesquisa.

São Paulo, de de 


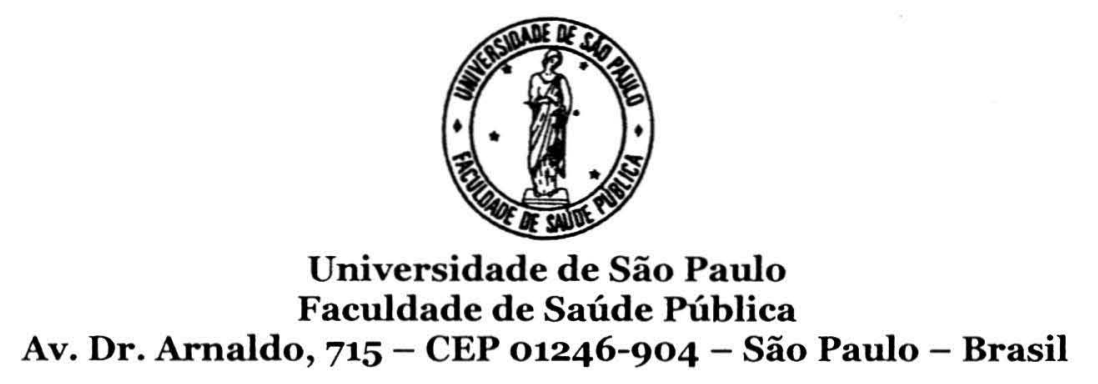

TERMO DE CONSENTIMENTO LIVRE E ESCLARECIDO

\section{I - DADOS SOBRE A PESQUISA}

5. Título do Protocolo de Pesquisa: Logística em Serviços de Saúde Pesquisador: Quésia Postigo Kamimura

Documento de Identidade $N^{0}: 16.157 .832$ Sexo: ( ) M $\quad$ (x) F Cargo/Função: Doutoranda

Departamento de Prática de Saúde Pública da Faculdade de Saúde Pública da Universidade de São Paulo.

6. Duração da Pesquisa: 4 (quatro) meses.

\section{II - REGISTRO DAS EXPLICAÇÕES DO PESQUISADOR AO SUJEITO DA PESQUISA OU SEU REPRESENTANTE LEGAL SOBRE A PESQUISA, CONSIGNANDO:}

A pesquisa proposta é de natureza acadêmica e tem como objetivo apresentar uma análise da evolução do sistema logístico no ambiente hospitalar e visa expandir os conhecimentos sobre um assunto recente e em desenvolvimento no mundo atual das organizações.

Para tanto será necessária a coleta de informações relacionadas ao sistema logístico das organizações hospitalares que serão pesquisadas por meio de documentos, entrevista semiestruturada junto a representantes da gestão hospitalar e visita de campo.

O participante é livre para expressar suas idéias e poderá fazer qualquer questionamento acerca do estudo e sobre sua participação nele, se tiver alguma dúvida procuraremos esclarecê-la em qualquer fase da pesquisa. A participação é voluntária e tem o direito de sair da pesquisa em qualquer etapa e em momento algum isto lhe trará prejuizos.

\section{III - ESCLARECIMENTOS DADOS PELO PESQUISADOR SOBRE GARANTIAS DO SUJEITO DA PESQUISA}

Os participantes da pesquisa terão direito de acesso, a qualquer tempo, às informações sobre procedimentos, riscos e benefícios relacionados à pesquisa, inclusive para dirimir eventuais dúvidas poderá entrar em contato com a pesquisadora por meio dos telefones 12-3832 5794 ou 12-9714 3988 e dos e-mails: qkamimura@uol.com.br ou qkamimura@usp.br e com o Comitê de Ética em Pesquisa da Sociedade Hospital Samaritano, telefone 1138215391. 
Fica claro que os participantes da pesquisa ou seu representante legal, podem, a qualquer momento, retirar seu consentimento e de deixar de participar do estudo e fica ciente que todo trabalho realizado torna-se informação confidencial, guardada por força de sigilo profissional.

\section{IV - CONSENTIMENTO PÓS-ESCLARECIDO}

Declaro que, após convenientemente esclarecido pelo pesquisador e ter entendido o que me foi explicado, consinto em participar do presente Protocolo de Pesquisa.

São Paulo, de de 


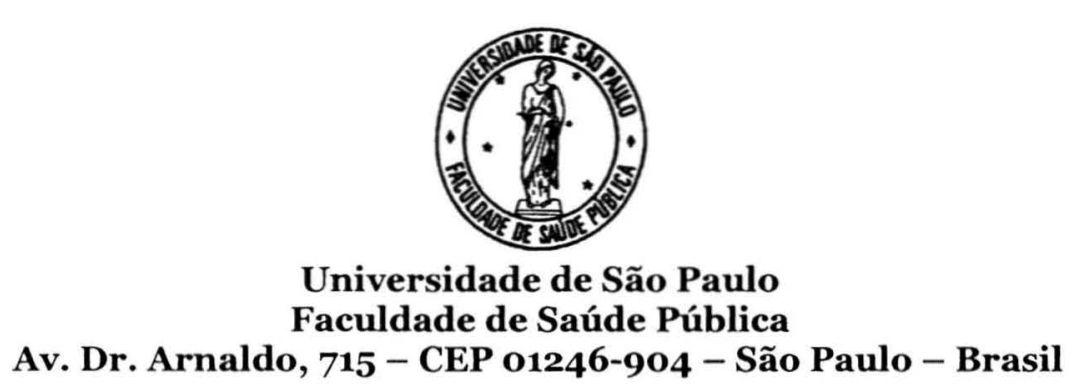

TERMO DE CONSENTIMENTO LIVRE E ESCLARECIDO

\section{I - DADOS SOBRE A PESQUISA}

7. Título do Protocolo de Pesquisa:.Logística em Serviços de Saúde Pesquisador: Quésia Postigo Kamimura

Documento de Identidade $N^{0}: 16.157 .832$ Sexo: ( ) M $\quad(x) F$

Cargo/Função: Doutoranda

Departamento de Prática de Saúde Pública da Faculdade de Saúde Pública da Universidade de São Paulo.

8. Duração da Pesquisa: 4 (quatro) meses.

\section{II - REGISTRO DAS EXPLICAÇÕES DO PESQUISADOR AO SUJEITO DA PESQUISA OU SEU REPRESENTANTE LEGAL SOBRE A PESQUISA, CONSIGNANDO:}

A pesquisa proposta é de natureza acadêmica e tem como objetivo apresentar uma análise da evolução do sistema logístico no ambiente hospitalar e visa expandir os conhecimentos sobre um assunto recente e em desenvolvimento no mundo atual das organizações.

Para tanto será necessária a coleta de informações relacionadas ao sistema logístico das organizaçőes hospitalares que serão pesquisadas por meio de documentos, entrevista semiestruturada junto a um representante da gestão hospitalar e visita de campo.

O participante é livre para expressar suas idéias e poderá fazer qualquer questionamento acerca do estudo e sobre sua participação nele, se tiver alguma dúvida procuraremos esclarecê-la em qualquer fase da pesquisa. A participação é voluntária e tem o direito de sair da pesquisa em qualquer etapa e em momento algum isto Ihe trará prejuizos.

III - ESCLARECIMENTOS DADOS PELO PESQUISADOR SOBRE GARANTIAS DO SUJEITO DA PESQUISA

Os participantes da pesquisa terão direito de acesso, a qualquer tempo, às informações sobre procedimentos, riscos e benefícios relacionados à pesquisa, inclusive para dirimir eventuais dúvidas poderá entrar em contato com a pesquisadora por meio dos telefones 12-3832 5794 ou 12-97143988 e dos e-mails: qkamimura@uol.com.br ou qkamimura@usp.br e com o 
Comitê de Ética em Pesquisa do Hospital Sírio Libanês, telefone 1131551145 ou 113155 1146 .

Fica claro que os participantes da pesquisa ou seu representante legal, podem, a qualquer momento, retirar seu consentimento e de deixar de participar do estudo e fica ciente que todo trabalho realizado torna-se informação confidencial, guardada por força de sigilo profissional.

IV - CONSENTIMENTO PÓS-ESCLARECIDO

Declaro que, após convenientemente esclarecido pelo pesquisador e ter entendido o que me foi explicado, consinto em participar do presente Protocolo de Pesquisa.

São Paulo, de de

Assinatura do entrevistado

ou responsável legal
Assinatura do pesquisador

Quésia Postigo Kamimura 


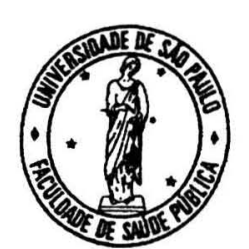

Universidade de São Paulo

Faculdade de Saúde Pública

Av. Dr. Arnaldo, 715 - CEP o1246-904 - São Paulo - Brasil

\section{TERMO DE CONSENTIMENTO LIVRE E ESCLARECIDO}

\section{I - DADOS SOBRE A PESQUISA}

Título do Protocolo de Pesquisa:.Logística em Serviços de Saúde

Pesquisador: Quésia Postigo Kamimura

Documento de Identidade $N^{0}: 16.157 .832$ Sexo: ( ) M $\quad$ (x) F

Cargo/Função: Doutoranda

Departamento de Prática de Saúde Pública da Faculdade de Saúde Pública da Universidade de São Paulo.

Duração da Pesquisa: 1 (um) mês.

II - REGISTRO DAS EXPLICAÇÕES DO PESQUISADOR AO SUJEITO DA PESQUISA OU

SEU REPRESENTANTE LEGAL SOBRE A PESQUISA, CONSIGNANDO:

A pesquisa proposta é de natureza acadêmica e tem como objetivo apresentar uma análise da evolução do sistema logístico no ambiente hospitalar e visa expandir os conhecimentos sobre um assunto recente e em desenvolvimento no mundo atual das organizações.

Para tanto será necessária a coleta de informações relacionadas ao sistema logístico das organizações hospitalares que serão pesquisadas por meio de documentos, entrevista semiestruturada junto a representantes da gestão hospitalar e visita de campo.

O participante é livre para expressar suas idéias e poderá fazer qualquer questionamento acerca do estudo e sobre sua participação nele, se tiver alguma dúvida procuraremos esclarecê-la em qualquer fase da pesquisa. A participação é voluntária e tem o direito de sair da pesquisa em qualquer etapa e em momento algum isto Ihe trará prejuizos.

III - ESCLARECIMENTOS DADOS PELO PESQUISADOR SOBRE GARANTIAS DO SUJEITO DA PESQUISA

Os participantes da pesquisa terão direito de acesso, a qualquer tempo, às informações sobre procedimentos, riscos e benefícios relacionados à pesquisa, inclusive para dirimir eventuais dúvidas poderá entrar em contato com a pesquisadora por meio dos telefones 12-3832 5794 
ou 12-97143988 e dos e-mails: qkamimura@uol.com.br ou qkamimura@usp.br e com o Comitê de Ética em Pesquisa do Hospital Israelita Albert Einstein, telefone 113747 - 1338.

Fica claro que os participantes da pesquisa ou seu representante legal, podem, a qualquer momento, retirar seu consentimento e de deixar de participar do estudo e fica ciente que todo trabalho realizado torna-se informação confidencial, guardada por força de sigilo profissional.

\section{IV - CONSENTIMENTO PÓS-ESCLARECIDO}

Declaro que, após convenientemente esclarecido (a) pela pesquisadora e ter entendido o que me foi explicado, consinto em participar do presente Protocolo de Pesquisa.

São Paulo, de de 


\section{Glossário}

$B 2 B$ - comércio eletrônico entre empresas.

B2C - comercio eletrônico de empresa para o consumidor.

Classificação ABC - No final do século XIX, o economista italiano Vilfredo Pareto constatou que a maioria da riqueza dos países é controlada por uma minoria de pessoas. Posteriormente, verificou-se que esse mesmo princípio aplicava-se a uma série de outros aspectos da atividade empresarial e passou a ser conhecido como Curva de Pareto, Curva 80-20 ou Curva ABC. Trata-se de classificação estatística de materiais, baseada no Princípio de Pareto, em que se considera a importância dos materiais, baseada nas quantidades utilizadas e no seu valor. Também pode ser utilizada para classificar clientes em relação aos seus volumes de compras ou em relação à lucratividade proporcionada; classificação de produtos da empresa pela lucratividade proporcionada, etc.

Neste estudo: Classe A: Grupo de itens mais importantes que devem ser tratados com uma atenção especial, quase que diária, pela administração do estoque; Classe B: Grupo de itens em situação intermediária entre as classes A e C; Classe C: Grupo de itens menos importantes que justificam pouca atenção, mas nunca nenhuma atenção, por parte da administração pelo estoque.

ECR - Consumer Response ou Resposta Eficiente ao Consumidor. Trata-se de software que permite o gerenciamento automático de estoques visando a reposição automática de itens, utilizando-se de código de barras, scanner, EDI etc. É um modelo estratégico de negócios, no qual fornecedores e varejistas trabalham de forma integrada, visando melhorar a eficiência na cadeia de suprimento, de forma a entregar maior valor agregado ao cliente/usuário final. Procura-se relacionar vendas finais no varejo com as programações de produção e a expedição com a cadeia de suprimento. Também chamado de Programa de Resposta Rápida (quick response) ou, simplesmente, Resposta Rápida.

EDI - Electronic Data Interchange ou Intercâmbio Eletrônico de Dados. É a troca automatizada, computador-a-computador, de informações de negócios/estruturas, entre uma empresa e seus parceiros comerciais, de acordo com um padrão reconhecido internacionalmente. Trata-se da troca eletrônica de documentos padronizados entre parceiros de uma cadeia de abastecimento ou entre unidades de uma mesma empresa separadas fisicamente. Quando associado ao uso do código de barras, leitoras óticas e sistemas de informações logísticas, constitui a base sobre a qual se viabiliza a implantação do ECR.

E-procurement - ferramenta eletrônica de cotação de preços, de compra e venda corporativas realizadas pela internet. 
Lead time - Tempo compreendido entre a primeira atividade até a última de um processo de várias atividades.

Just in time - é atender ao cliente interno ou externo no momento exato de sua necessidade, com as quantidades necessárias para a operação/produção, evitando-se assim a manutenção de maiores estoques.

Pyxis - gabinetes automatizados utilizados na distribuição de medicamentos em substituição de Farmácias Satélites e "Farmacinhas" do posto de Enfermagem.

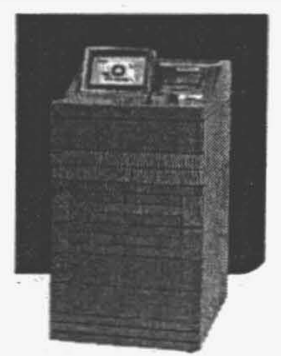


possui graduaçảo em Curso de Direito pela Facuidade de Direito da Universidade Mackenzie (1971), mestrado em Saúde Pública pela Universidade de São Paulo (1984) e doutorado em Saúde Pública pela Universidade de Sảo Paulo (1991). Atualmente é professor associado da Universidade de São Paulo. Tem experiència na área de Saúde Coletiva, com ênfase em Administração Hospitalar. atuando principalmente nos seguintes temas: recursos humanos, custos, avaliacão qualitativa. capacitacão e desenvolvimento e gestão em serviços de saúde.

Texto informado pelo autor

Última atualização do currículo em 14/10/2008

Endereço para acessar este CV:

http://lattes.cnpq.br/1002485404161345
Certificado

pelo autor em

$14 / 10 / 08$

Dados pessoais

Nome Vitória Kedy Cornetta

Nome em citações CORNETTA VK.

bibliográficas

Sexo Feminino

Endereço profissional Universidade de São Paulo. Faculdade de Saúde Publica. Departamento de Prática de Saúde Pública.

Av Dr. Arnaldo, 715 - $1^{\circ}$ Andar - Sala 103

Cerqueira César

01246904 - Sao Paulo, SP - Brasi

Telefone: (11) 30667706 Fax: (11) 30829659

URL da Homepage: http://www.fsp.usp.br/hsp

Formação acadêmica/Titulação

1995 Livre-docência.

Universidade de São Paulo, USP. Brasil.

Titulo: Municpalização da Saúde:, Ano de obtenção: 1995.

Grande área: Ciências da Saúde / Área: Saúde Coletiva / Subárea: Saúde Pública / Especialidade: Administração

Hospitalar.

Setores de atividade: Politicas, planejamento e gestão em saúde

1987 - 1991 Doutorado em Saúde Pública 25.

Universidade de São Paulo, USP, Brasil.

Titulo: Comparação da Força de Trabalho em Serviços de Saúde, Ano de Obtenção: 1991.

Orientador: Lourdes de Freitas Carvalho.

Grande área: Ciências da Saúde / Area: Saúde Coletiva / Subárea: Saúde Pública / Especialidade: Administração Hospitalar.

Setores de atividade: Politicas, planejamento e gestão em saúde.

1979 - 1984 Mestrado em Saúde Pública 65

Universidade de São Paulo, USP, Brasil.

Título: Implantação do Serviço de Arquivo Médico e Estatística em um Hospital Universitário, Ano de Obtenção: 1984

Orientador: Lourdes de Freitas Carvalho.

Grande área: Ciências da Saúde / Área: Saủde Coletiva / Subárea: Saúde Pública / Especialidade: Administração Hospitalar.

Setores de atividade: Politicas, planejamento e gestão em saúde.

1979 - 1979 Especialização em Planificación de La Salud.

Escola de Saúde Pública da Universidade de Medelin Antióquia, ESPUM, Colômbia.

1974 - 1975 Especialização em Ciências Em Records Médicos.

Faculdade de Saúde Pública da Universidade do Porto Rico Estados Unidos, FSPUPR, Porto Rico.

1972 - 1973 Especialização em Especialização Em de Administração Hospitalar.

Universidade de São Paulo, USP, Brasil.

1967 - 1971 Graduação em Curso de Direito. Faculdade de Direito da Universidade Mackenzie, FDUM, Brasil.

\section{Atuação profissional}

Universidade de São Paulo, USP, Brasil.

Vinculo institucional

1995 - Atual Vinculo: Servidor Público, Enquadramento Funcional: Professor Associado, Carga horária: 40, Regime: Dedicação 


\title{
Quésia Postigo Kamimura
}

Possui graduação em Ciências Econômicas pela Pontificia Universidade Católica de Campinas e mestrado em Administração e cursando doutorado. Tem experiência na área de Administração, atuando principalmente nos seguintes temas: saúde, logística em serviços, regionalização, recursos sustentáveis e comportamento organizacional.

(Texto informado pelo autor)

Última atualização do currículo em 06/01/2009

Endereço para acessar este CV: http://lattes.cnpq.br/7058502976831665

\section{Certificado}

pelo autor em

$06 / 01 / 09$

Dados pessoais

\author{
Nome Quésia Postigo Kamimura \\ Nome em citações KAMIMURA, Q.P. \\ bibliográficas \\ Sexo Feminino \\ Endereço profissional Universidade de Taubaté. \\ Av. Granadeiro Guimarães \\ centro \\ 12020-000 - Taubate, SP - Brasil \\ Telefone: (12) 38322460
}

Formação acadèmicalTitulação

2006 Doutorado em Saúde Pública

Universidade de São Paulo, USP, Brasil.

Título: Análise dos serviços de saúde., Orientador: Profa. Dra. Vitória Kedy Cornetta.

2002 - 2004 Mestrado em Administração.

Universidade de Taubaté, UNITAU, Brasil.

Titulo: A Microrregionalização como estratégia de organização dos serviços de saúde no I Ano de Obtenção: 2004.

Orientador: $Q$ Profa. Dra. Vera Lúcia Ignácio Molina.

Grande área: Ciências Sociais Aplicadas / Área: Administraçăo.

Grande área: Ciências Sociais Aplicadas / Área: Administraçăo / Subárea: Administraçăo de Em Grande área: Ciências Sociais Aplicadas / Área: Administração / Subárea: Gestão e Desenvolvir Setores de atividade: Administraçăo pública, defesa e seguridade social; Qualidade e Produtivid: e administração pública em geral.

1999 - 2001 Especialização em Saude Publica. (Carga Horária: 496h).

Universidade de São Paulo, USP, Brasil.

Título: Aplicação do Método PES no Sistema de Saúde no Município de Ubatuba/SP.

Orientador: Dr. Eurivaldo S. Almeida e Dr.Cláudio Gastão J. Castro.

1985 - 1992 Graduação em Ciências Econômicas. Pontificia Universidade Católica de Campinas, PUC Título: As Condicionantes Sócioeconômicas na Mortalidade de 1 a 5 anos no Estado de $\mathrm{S}$ Orientador: Profa. Dra. Maria Leite.

Atuação profissional

Fundação Universitária de Taubaté, FUST, Brasil.

Vínculo institucional 